\title{
MMSTER
}

\section{Irradiation Performance of HTGR Fuel Rods in HFIR Experiments HRB-4 and -5}

\author{
F. J. Homan \\ E. L. Long. Jr. \\ R. L. Hamner \\ B. H. Montgomery \\ K. H. Valentine \\ M. J. Kania
}

\section{OAK RIDGE NATIONAL LABORATORY}

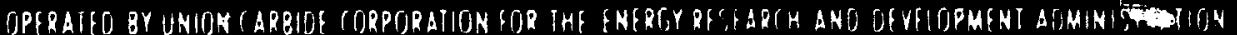

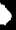


Pr:nted in the United States c: America. Available from National Techricai information Service

U.S. Depar:ment of Commerce

5285 Port Royal Road, Springfield. Virginia 22161

Price: Printed Copy 55.00: Mirrof ishe \$2.25

This report was prepored as an account of work sponsored by the United States Government. Heither the Unefed States nor the Energy Rasearch and Dewwopment Administrationiunited States Nuchar Reculatory Commisson, nor any of their employes. ner any of their contractors, subcontractors, or that emploves, mokes

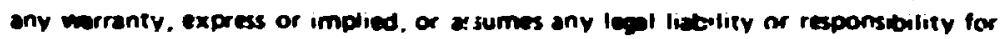
the eccuracy. completeness or sefulness of eny informetion, epopratus. product or process disclosed, or represents that its use would not intringe pricotely onmed riphts. 
ORLL-5i15

uC-77 (Gas-Cooled

Reactor Technology)

\author{
Contract No, $\mathbf{W - 7 4 0 5 - e n g - 2 6}$ \\ METALS AND CERAMICS DIVISION \\ HTGR BASE TECHNOLOGY PROGEAM
}

Fueled Graphite Development (18Sa $\mathrm{GHOO2)}$

IRRADIATION PERFORMANCE OF HTGR FUEL RJDS

IN HFIR EXPERIMENTS HRB-4 AVD -5

F. J. Homar, E. L. Long, Jr., R. L. Hamner,

B. H. Muntgonery, K. H. Valentine, and M. J. Kania

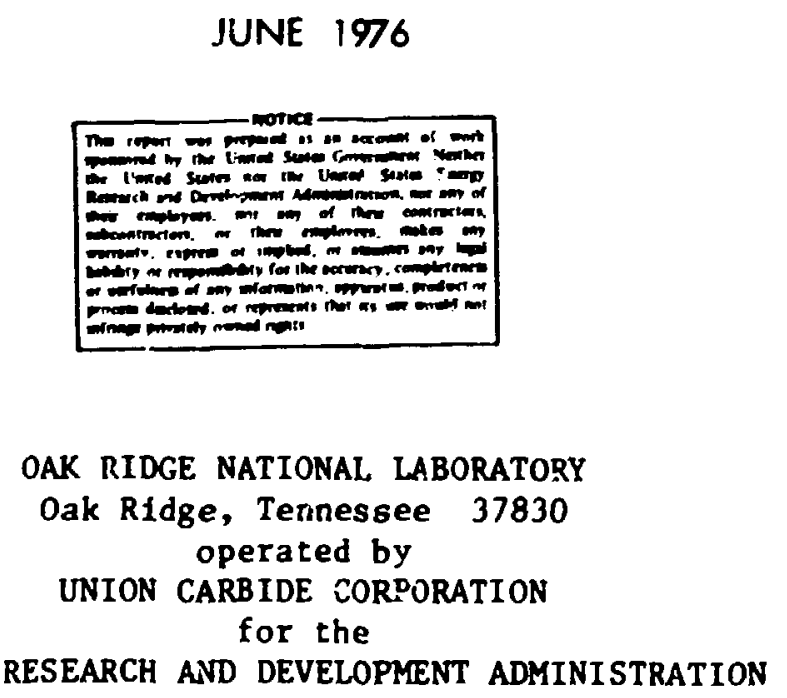


CONTENTS

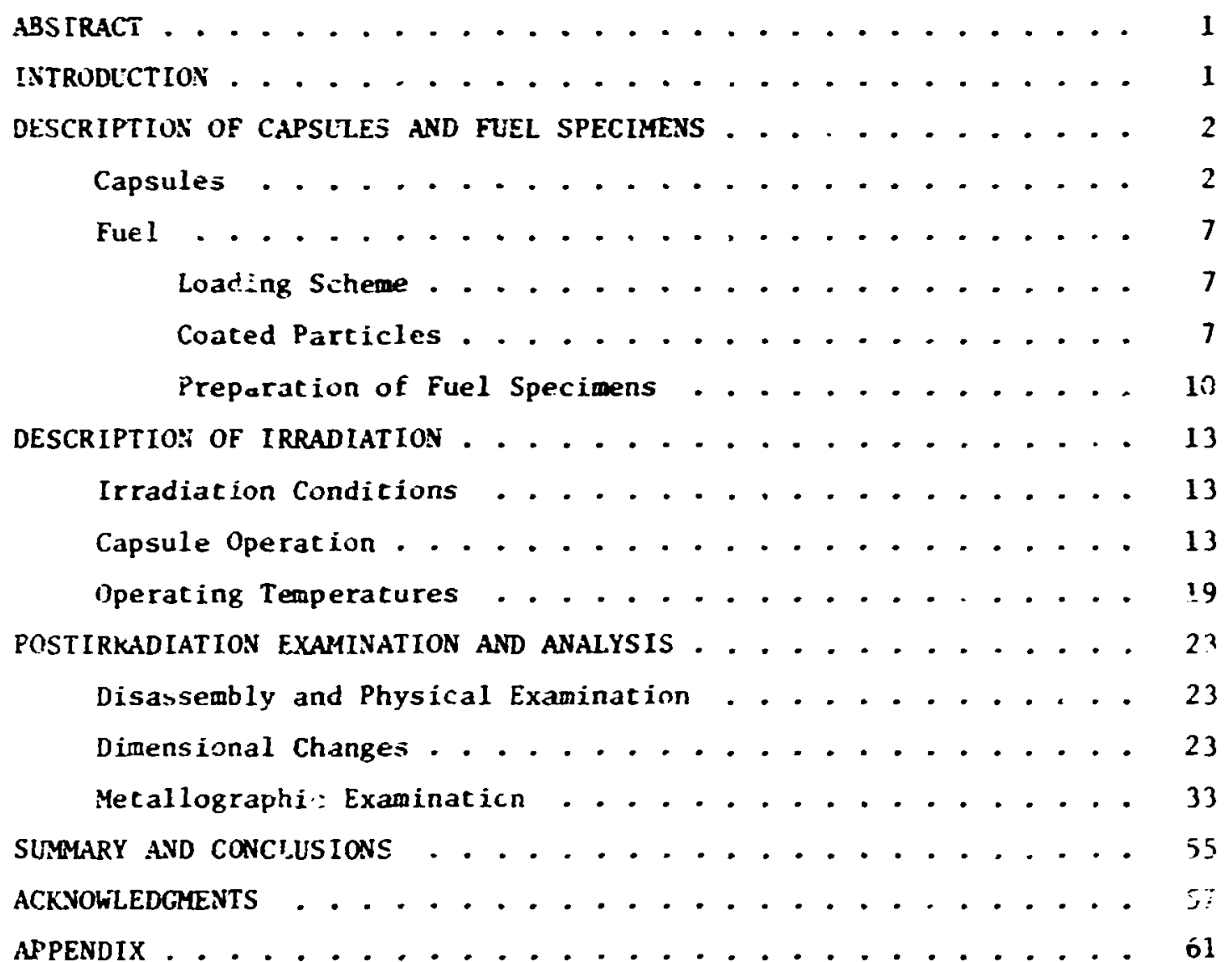

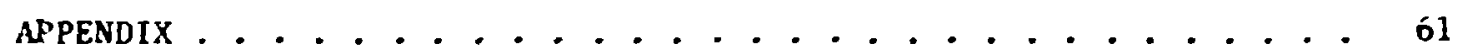


IRRADEATZOA PERFORMANCE OF HTGR FUEL RODS

IN HFIR EXPER DREITS HBR-4 AND -5

F. J. Homan, E. L. Long, Jr ., R. L. Hanner,

B. H. Montgonery, K. H. Valentine, and M. J. Kanja

\begin{abstract}
Experiments HRB- 4 and -5 were the first tests of weakacid-resin-derived fissile fuel. This fuel was later selected as the reference recycle fissile kernel. The War-derived kernels did not exhibit thermal agration during irradiation, but there was sone concentration of rare-earth fission products at the inner surface of the SiC coating. These experiments were also a test of fuel rods carbonized in graphite subes, to simulate in-block carbonization. The results of these tests showed significant problens associated with in-block carbonization, notably a mechanical interaction between particles and eatrix material. A significant development prcgran was launched to solve these problens. ARB-4 and -5 also included three specinens presared by an extruston fabrication route. These specineis generally psrformed vell, although sone tiny cracks in the SIC layer, apparently caused by the fabrication prccess but acc mntuated by the irradiation, were noted.
\end{abstract}

\title{
INTRODUCTION
}

The fourth and fifth capsules were HRB- 4 and -5 in the series of irradtation experiments conducted in the removable beryllium (RB) reflector facility of the High Flux Isotope Reactor. The first three experinents and the sixth experiment have al ready been documented. ${ }_{4}$

1J. L. Scott et al., An Irradiation Test of Bonded HTGR Coated Particle Fuels in an Instrwnented Capsule in HFIR, ORNL-MM-3460 (March 1972).

${ }^{2} \mathrm{~J}$. H. Coobs et al., Imadiation Performance in HFIR Experiment HRE-2 of HTCR Fuel Sticks Bonded with Reference and Adunced Matrix Matemia?s, ORNL-TM-3988 (January 1973).

${ }^{3}$ F. J. Homan et al., Imadiation Perjormance of HTGR Rue? Rods in HFIR Experiment HRB-3 and ETR Experiment P13N, ORNL-TM-4526 (October 1974).

'F. J. Homan et al., Irradiation Performance of HTCR Fuel Rods in HFIR Expemiment HRB-6, ORNL/TM-5011 (in press). 
Some information oit the HRB-4 and -5 capsules has been puiblished in anrual reports. ${ }^{5,6}$ is has been the case vith previous HRB capsules, the space in HRB-4 and $-j$ was shared witi General Atonic Company (GAC). This report will deal wostly with the ORNL fuel rods irradiated in these capsules.

The ORM fuel rods in ti. HRB-y and -5 capsules containec three types of particles. The fissile particles were weak-acid-resin (UAR) loaded kernels, Triso coated. ine fissile kernels were fully converted to the carbide $\left(U C_{2}\right)$ for. She fertile particles vere Biso-coated $\mathrm{ThO}_{2}$ prepared by the sol-gel nethod. The third type of particle was inert and contained a kernel derived from strong-acid resin (SAR). The SAR kernels were heated to $3000^{\circ} \mathrm{C}$ before coating to elininate sulfur. Both Biso- and Triso-coated inerts were used in this experinent, which was the first test of MAR-derived sissile fuel.

The objectives of the HRB- 4 and -5 experinents were:

1. to test slug-injected bonded fuel rods prepared with different matrix materials and by different carbonization methods,

2. to test experimental fuel rods fabricated by GAC,

3. to test extruded fuel rod specimens,

4. to measure central fuel temperatures and monitor changes in thereal conductivity of extruded rods, and

5. to screen HAR-derived fuel for potential use in fissile particles. Ail of these objectives were accomplished except No. 4. HRB-4 contained a tungsteri-rheniu central thermocouple which decalibrated badly during the irradiation. In HRB-5 a 2-in.-long rhenium ultrasonic themometer was used instead of a center thermocouple. This device decalfibrated even nore than the tungsten-rhenium -hermocouple used in HRB-: : The centerline temperature data from the HRB- 4 and -5 experiments have been of no value, although efforts are still under way to develop techniques for correction of the readings.

Each capsule contained 13 fuel specimens. Three specimens in each capsule were fabricated by extrusion (ORNL specimens) and the remainder by slug injection. There were six fuel rods in each capsule fabricated by GAC.

DESCRIPTION OF CAPSULES AND FUEL SPECIMENS

Capsules

The HRB-4 and -5 capsilles were similar in design to the previous capsules in this series. Thirteen fuel rod specimens were inserted into a tapered, one-plece graphite sleeve made of Poco grade AXF-5Q.

${ }^{5}$ GCR Prograns Anru. Progr. Rep. Dec. 31, 1972, ORNL-4911, PP. 107-12.

'GCR Programs Annu. Progr. Rep. Dec. 31, 1973, ORNL-4975

(in press). 
The sleeve uas located inside a prinary containent capoule, which was in turn located inside a secondary containent capsule; both capsules vere ande of stainless steel. A cross section of the tine-4 and -5 capsules is shown in Fig. 1. The noninal dinensions of the fuel and graphite sleeve are given in Fig. 2. The outsiae and inside diameters of the secondary containent capsule were 1.292 and $1.1 \% 0 \mathrm{in}$., respectively, and 1.137 and $0.9676 \mathrm{ln}$., respectively, for the primary containment. The taper of the graphite sleeve was somentat different for the HRS-4 and -5 capsules than for other capsules in this series. Figure 2 does not accurately display the taper. There were actually two tapers in the botton purtion of the sleeve, as shown in Fig. 3. Other capsules had only one taper at each end, and capsules fron birb-7 on have had no taper. Figure 3 also shows the postirradiation shape of the capsule, which will be discussed in Eore detall later in this rcport. Figure 3 does not show the exact shape of the graphite sleeve; rather it shows the increase in size over the ainim dianeter of 0.825 to $0.827 \mathrm{fa}$. (0 anc $90^{\circ}$ orientations) at the botton of the capsule. The tapered graphice sleeve was used to compensace for the axial variation in neutron flux and gama heating characteristics. Both flux and gama heating rate (and therefore the fuel specinen heat generation rates) de:rease as approxisately a cosine function with distance from the reactor horizontai aidplane. In order to obtain reasonably uniform specimen temperatures with this axially varying heat generation pattern, the theral resistance of the radial gas gap between the graphite sleeve and the stainless steel capsule vall was increased through the use of the taper.

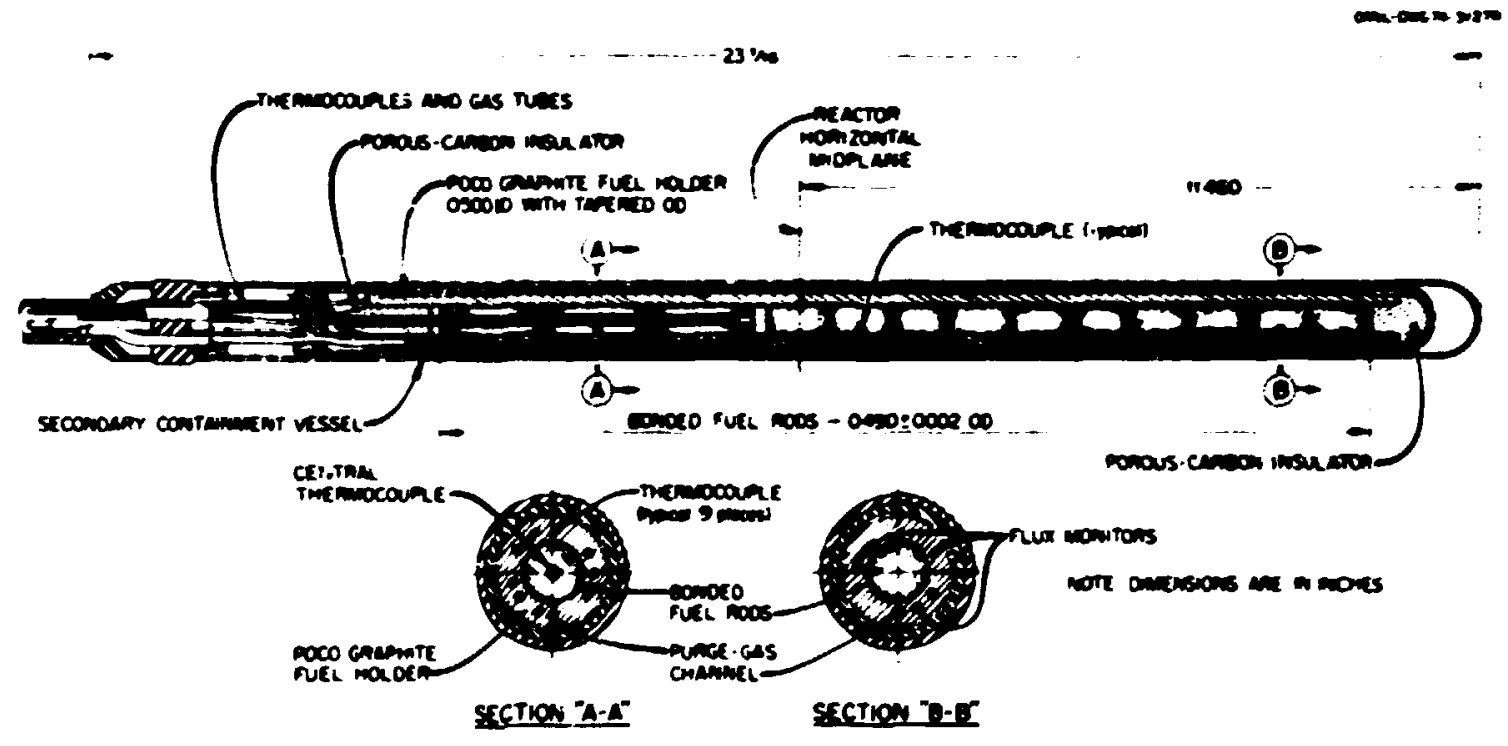

Fig. 1. HTGR Instrumented Capsules HRB-4 and -5 Irradiaced in HFIR Removable Beryllium Facility. 


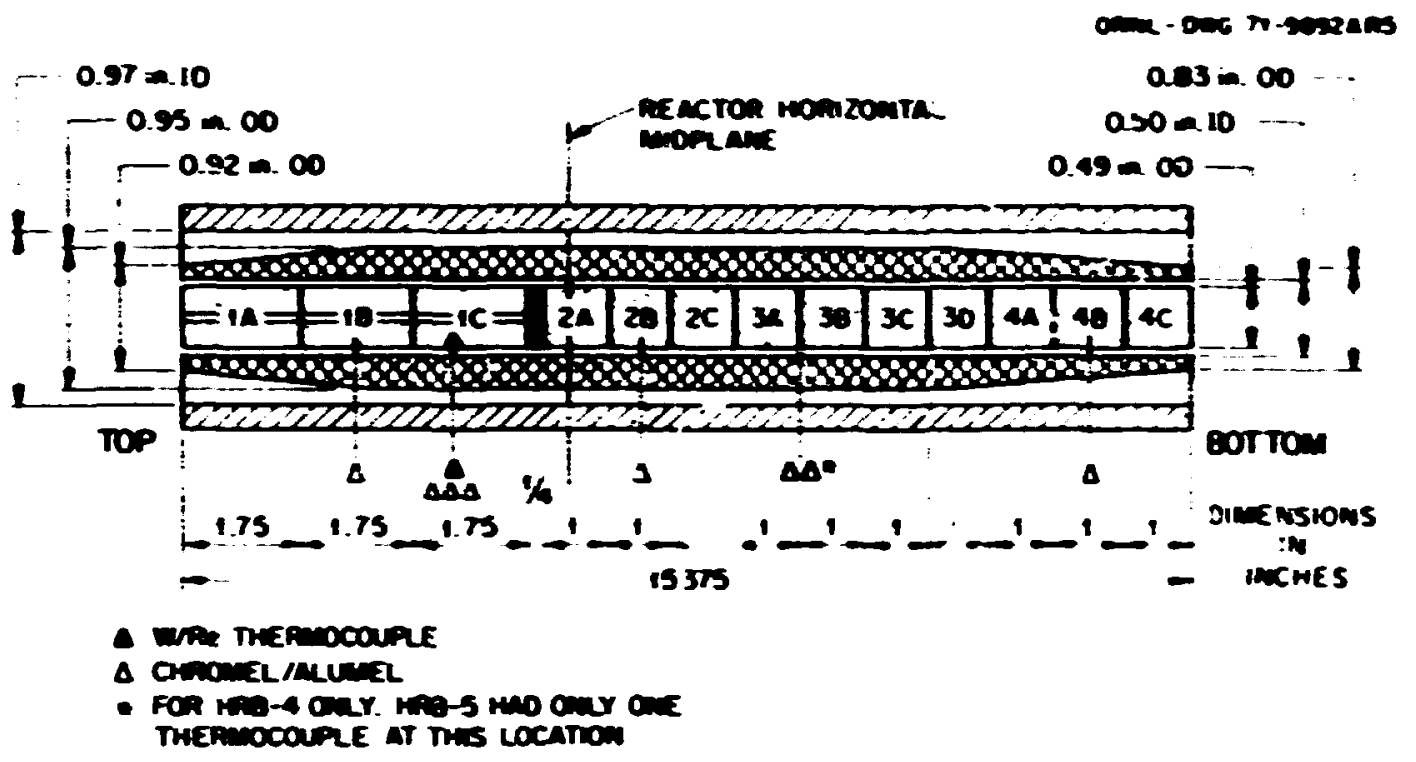

Fi8. 2. HRB-4 and -5 configuration.

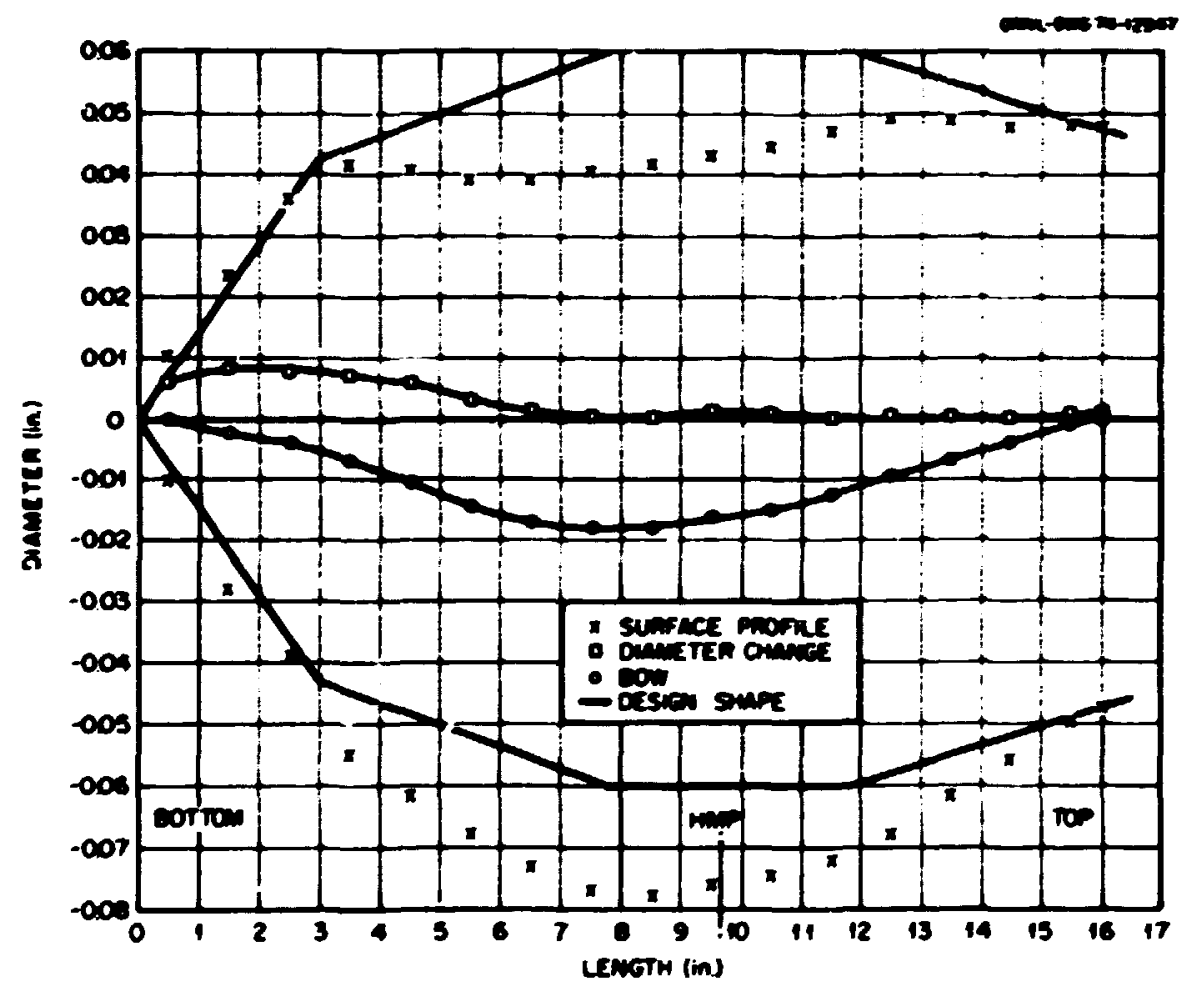

F18. 3. Graphite Sleeve Dimensions for Capsule HRB-4 $0^{\circ}$ Orientation. 
Temperateres inside the capsules were woitored with eigh: Chromel-Aluel thernocouples and one ceaterline thernoneter. located as shown in Fig. 4. In bin-4 the centerline thennoeter vas a

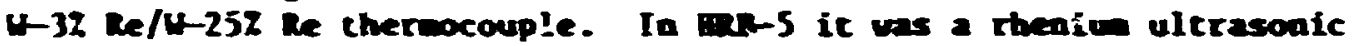
thermoneter (see Sect. 2.7 of Ref. 6 for a description of this device). The Chromel-Alunel thernocouples were 0.062 in. In dianeter and sheathed with stainless steel. Six of these thenocouples in bus- were coated with a 0.005-in.-thick protective barrier of tursten applied by rapor deposition; two were uncoated. Wo difference was noted in the performance of the coated vs the uncoated thermocouples; therefore, ir. subsequent experinents the coatings were not applied. The bare vire W/Re thernocouple used in HRb-4 was threaded through a cwo-bole 0.062-in. dian Beo insulator. The juaction and lower 2 in. of the insulator vere sinielded from the fuel surface by a three-layer urap of 0.00 is-in.-thick theniun foil. The foil can be seen in the $x$ radiograph (F18- 5). The upper fuel specimens, 1A, 1B, and IC, had a 0.092-in. ceatral hole to accomodate the ceat.erline thenometer. High-purity Fe, Mi, Ti, and Co flux sonitors in beo tubes were located in the graphite sleeve in axial holes similar to those for the therncouples. The graphite sleeve and fuel specinens were coctinuously swept with a $3600-\mathrm{cm}^{3} / \mathrm{hr}$ high-purity heliu-neon gas axture at 1 to 2 ate. Gas samples of the sweep effluent were taken periodicall; for fission gas release deterninations.

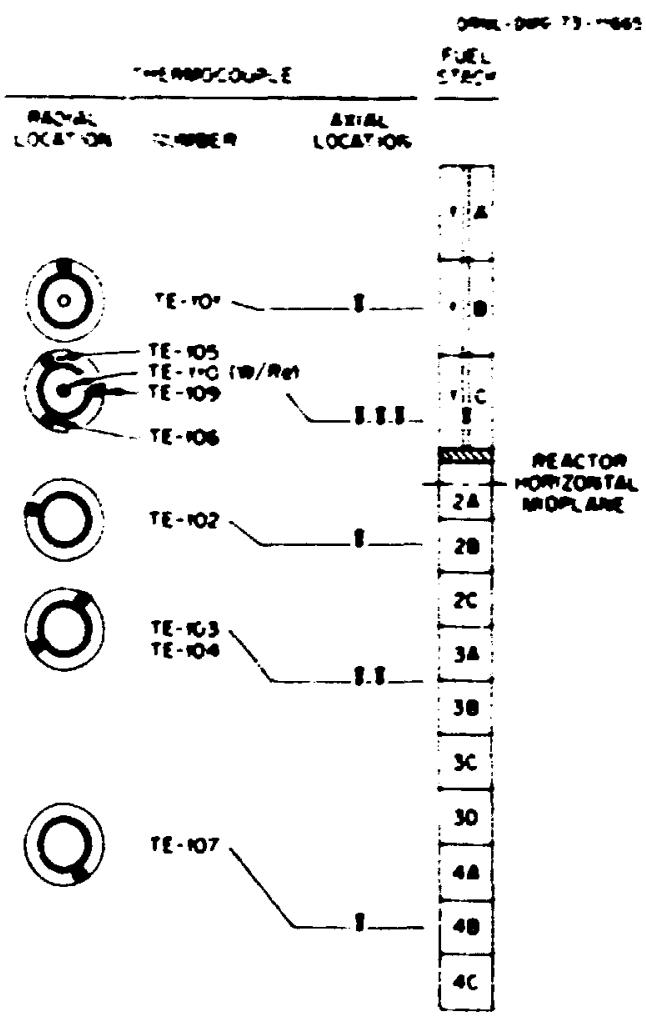

Fig. 4. Capsule HRB-4 Fuel Specimen and Thermocouple Locations. 


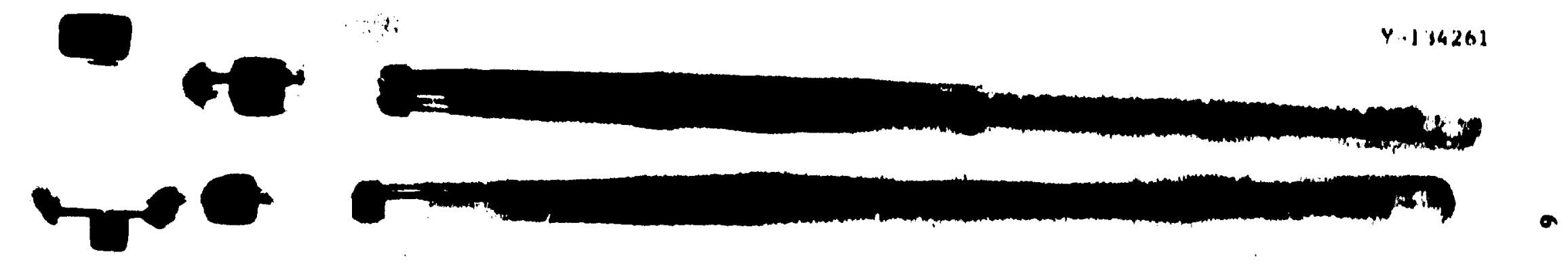

F18. 5. Preirradiation X Radiograph of Capaulea HRs-4 and -3 . 
The sweep gas is present for teaperature coatrol as well as deternination of the ratio of fission gas release gate 'o birth race. The theraal neutron fiux increases drastically at all axial locations durine the approximately 23-day irradiation cycle. The percentage increase is greater at the eads of the apsule than at the torizontal mijy lane. To mintain cunstant operat ing cenperatites under these condicions, it is necessary to vary the thermal resistance across the gas gaps. This is dome vich a varying hel 10 -neon gas aixture. A higl: proportion of lou-conductivity nen: is used early in the cycl=. when the thereal neutron flux is relatively low. Sore helive is used later ia the cycle, when the neutron flux increases. Howerer, because of the difference in the rate of $f(u x$ increase at different arial locatioas, it is not possible to axintain exactly constant cenperatures for 21 i spesireas.

Fuel

\section{Lading Schene}

The eypes and mubers of specinens were ideatical for both capsules. A cotal of 13 speciners were irradiated in each expertient, six of wich were fabricated by raC and seven by ORal. Of the seven ORal specinens in each capsule, three were extrusions and the reafning four were fabricated by siug injectior. The loading schene is shown in Fis. 2; specimens $1 A, I B$, and $I C$ are the ectrusions; specinens $2 A, 2 B, 2 C, 4 A$, 48, and $4 C$ are the $C A C$ rods. The fuel loadings and dizensions for all specimens in both capsules are show in Tables 1 and 2.

\section{Coated Particles}

All ORN specimens contained the same Triso-coated fissile, bisocoated fertile, and coated inert particles. The fissile partisles were derived from weak-acid resins and were reduced and converted to the carbide form. Fetrile particles vere $\mathrm{ThO}_{2}$ microspheres prepared by the sol-gel method. Coatings specified for these particles were conservacively designed. The coated inert particles (used for shin) had kernels chat were derived from strong-acid resins, heased to $3000^{\circ} \mathrm{r}$. before coating to elfinate sulfur. All suated-particle batches were heated to $1800^{\circ} \mathrm{C}$ before fabrication into fuel rods to relieve residual stresses that aght lead to coating breakage during fabrication. The characteristics of these particles are given in Table 3. 
Table 1. Capsule HRB-4 Fuel Specimen Location and Loading

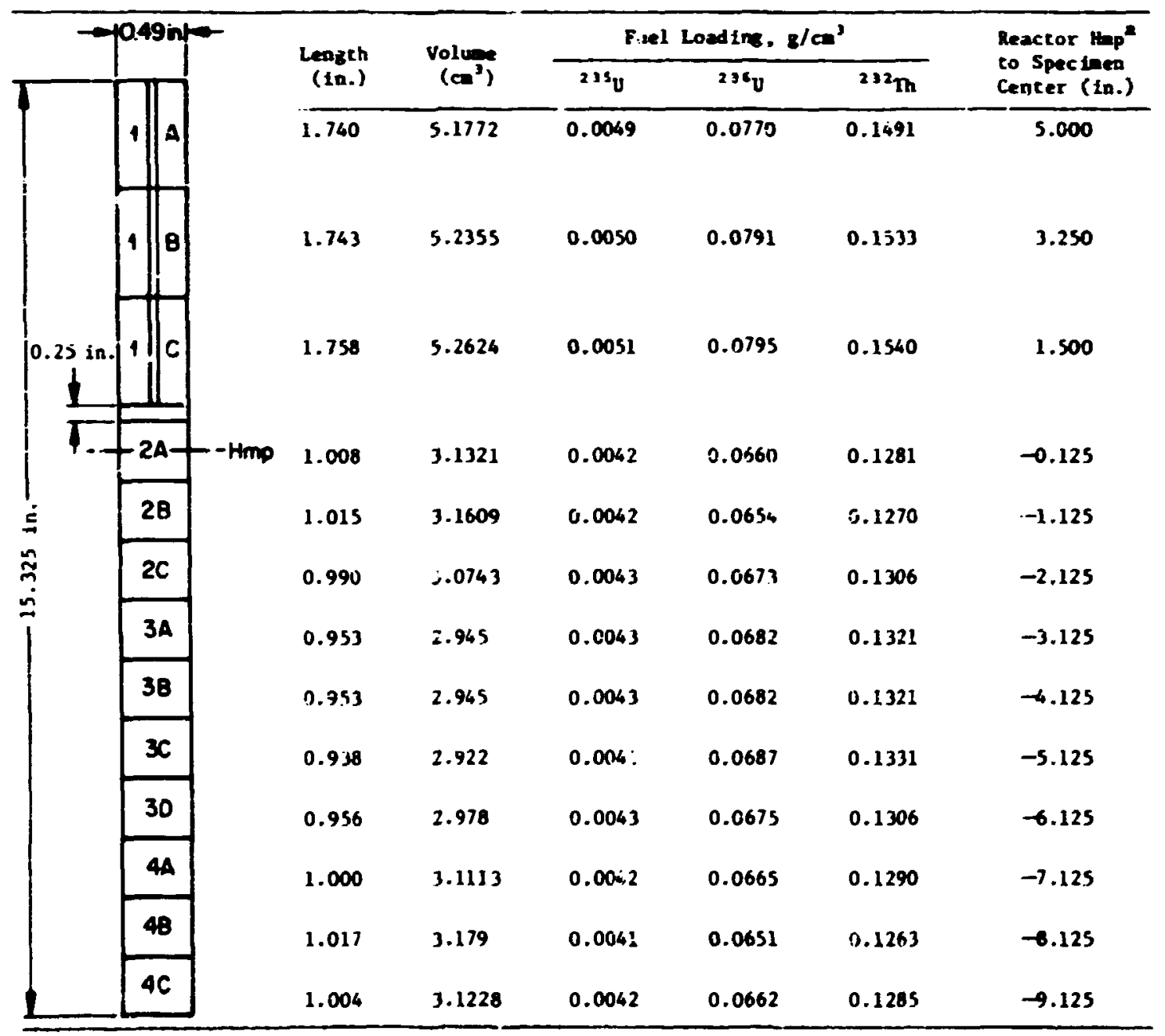

${ }_{\text {Htmp }}=$ horizonta: : sldplane. 
Table 2. Capsule HRB-S Fuel Specisen Location and Loading

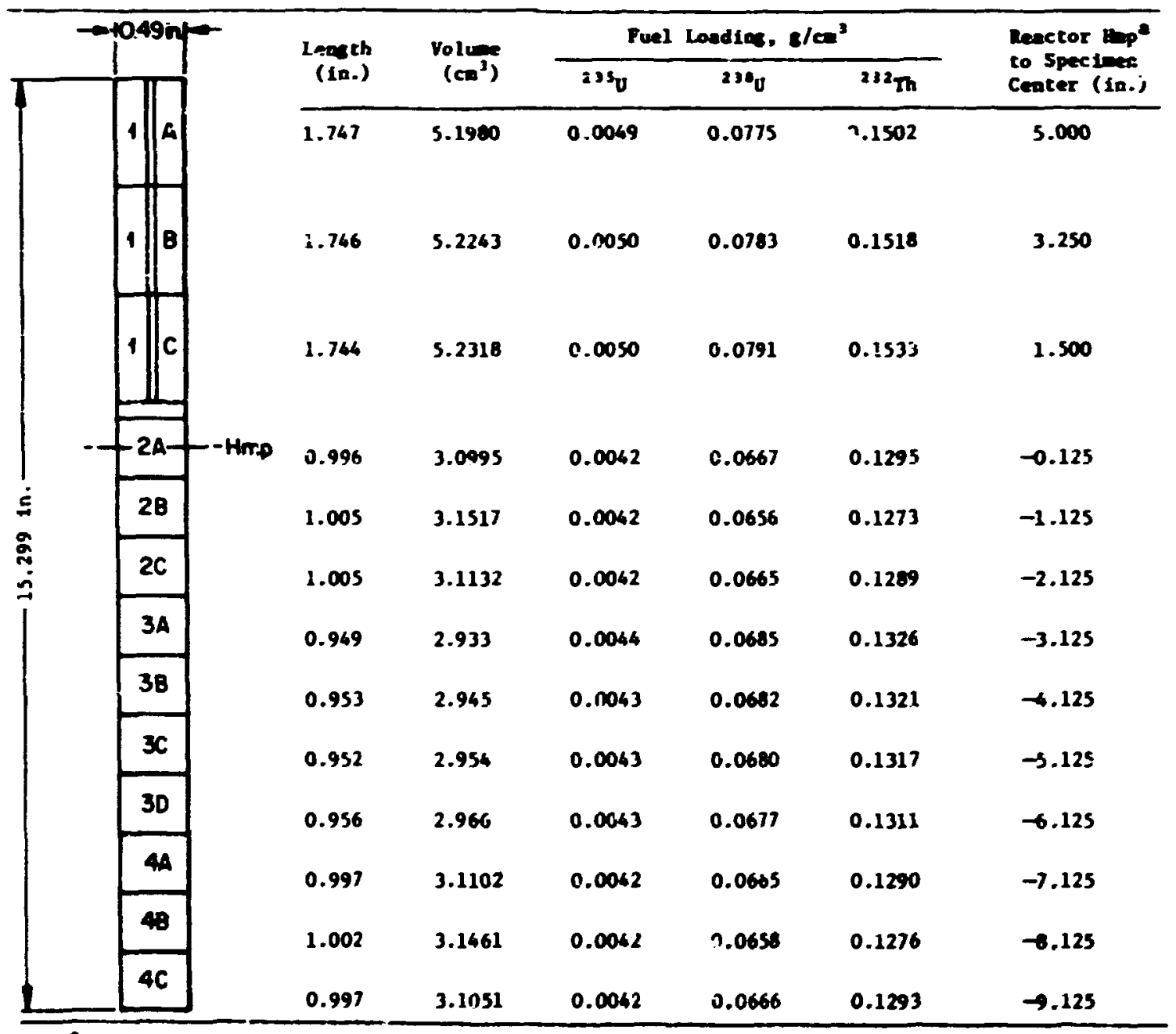

thep - hordzontel exdpleace. 
Table 3. Characterization of Coated Particles for HRB-4 and -5

\begin{tabular}{|c|c|c|c|c|}
\hline Batch Number & $52 A$ & OR-1856 & OR-1833 & $O k-1815$ \\
\hline \multicolumn{5}{|l|}{ Kernel } \\
\hline $\begin{array}{l}\text { Type eaterial } \\
\text { Uranium content, we } z \\
\text { z's enrichent, at. } 7 \\
\text { Thorium content, ut } z \\
\text { Dianter, La } \\
\text { Density, } 8 / \mathrm{cm}^{3}\end{array}$ & $\begin{array}{l}U C_{2}^{d} \\
23.8 \\
5.99 \\
366^{d}=42^{e} \\
6.2\end{array}$ & $\begin{array}{l}56.62 \\
48:=30 \\
9.72\end{array}$ & $\begin{array}{l}370^{5} \\
1.4\end{array}$ & $\begin{array}{l}370^{t} \\
1.4\end{array}$ \\
\hline \multicolumn{5}{|l|}{ Buffer } \\
\hline $\begin{array}{l}\text { Thickness, iv } \\
\text { Density, } 8 /=\mathrm{n}^{3}\end{array}$ & $\begin{array}{l}44.6 \div 6 \\
0.95 f\end{array}$ & $\begin{array}{l}88 \pm 8 \\
0.95 f^{8}\end{array}$ & $\begin{array}{l}20^{f} \\
1.0^{f}\end{array}$ & $\begin{array}{l}30^{\mathrm{f}} \\
1.0^{\mathrm{f}}\end{array}$ \\
\hline \multicolumn{5}{|l|}{ Inner carbon coating } \\
\hline $\begin{array}{l}\text { Thickness, wn } \\
\text { Density, : / }\end{array}$ & $\begin{array}{l}30.8 \div 4 \\
1.94: 0.01\end{array}$ & & $\begin{array}{l}20^{i} \\
1.90 \cdot 0.06\end{array}$ & \\
\hline \multicolumn{5}{|l|}{ Sic } \\
\hline $\begin{array}{l}\text { Thickness, it } \\
\text { Densits, g/co3 }\end{array}$ & $\begin{array}{l}31.8 \div 6.6 \\
3.21 \div 0.006\end{array}$ & & $\begin{array}{l}15 \pm 2 \\
3.21 \div 0.002\end{array}$ & \\
\hline \multicolumn{5}{|l|}{ Outer carbon coat ing } \\
\hline $\begin{array}{l}\text { Thickness, in } \\
\text { Density, gicn }\end{array}$ & $\begin{array}{l}28.3 \pm 3.9 \\
1.89 \pm 0.007\end{array}$ & $\begin{array}{l}79 \div 7 \\
1.92 \div 0.023\end{array}$ & $\begin{array}{l}30^{\mathrm{f}} \\
1.98 \pm 0.004\end{array}$ & $\begin{array}{l}30^{\mathrm{f}} \\
1.92 \pm 0.022\end{array}$ \\
\hline Crushing strengch, io & $3.44 \pm 0.976$ & $3.96 \div 0.955$ & $1.88 \div 0.425$ & $1.33 \pm C .639$ \\
\hline
\end{tabular}

Weak-acid resin derived.

bsol gel derived.

cstrong-acid resin derived.

Mean.

Standard deriation.

f standard deviation not deternined.

\section{Preparation of Yuel Specimens}

A general description of the fuel rod specimens for the two capsules is presented in Table 4. The graphitized Robinson coke was selected for the extrusions because it is isotropic and irradiation resistant. Thermax was added to the filler as an afd for extruston. Varcum was selected as a binder because of its low viscosity at room temperature. All components were slurry blended with acetone until the solvent had evaporatsd. The mix was then extruded at room temperature and at a pressure of $1000 \mathrm{psi}$ into graphite trays, cut to lergth in the green state, cured $16 \mathrm{hr}$ at $90^{\circ} \mathrm{C}$, carborized at $1000^{\circ} \mathrm{C}$ on a $24-\mathrm{hr}$ cycle, then finally heat treated at $1800^{\circ} \mathrm{C}$ to dimensiorially stabilize the matrix. Due to some variation in the consistencies of different extrusion batches, matrix densities varled between 1.6 and $1.7 \mathrm{~g} / \mathrm{cm}^{3}$, but they were considered acceptable for the experiments. Fuel distribution in the specimens appeared to be good, as shown by the radiograph in Fig. 5 . 
Table 4. General Description of Spectmens for HRB-4 and -5

\begin{tabular}{|c|c|c|c|c|c|c|c|c|c|}
\hline \multirow{2}{*}{$\begin{array}{l}\text { Spec:inen } \\
\text { Number }\end{array}$} & \multirow{2}{*}{ Suppller } & \multirow{2}{*}{$\frac{\text { Noninal }}{\text { ob }}$} & \multicolumn{2}{|c|}{ Dimenalons, in. } & \multicolumn{2}{|c|}{ Flller Materiala } & \multirow{2}{*}{$\begin{array}{l}\text { Particle } \\
\text { Volume } \\
\text { loadinx } \\
(y)\end{array}$} & \multirow{2}{*}{$\begin{array}{l}\text { Fahrication } \\
\text { roclinique }\end{array}$} & \multirow{2}{*}{$\begin{array}{l}\text { Larbonleastion } \\
\text { Mode }\end{array}$} \\
\hline & & & 10 & Length & $\begin{array}{l}\text { Amiunt } \\
(w i x)\end{array}$ & Typun & & & \\
\hline $\begin{array}{l}\text { IA } \\
\text { iB } \\
\text { IC }\end{array}$ & $\begin{array}{l}\text { ORNL } \\
\text { ORNL } \\
\text { ORNL. }\end{array}$ & $\begin{array}{l}0.430 \\
0.490 \\
0.490\end{array}$ & $\begin{array}{l}0.090 \\
u . n 90 \\
0.030\end{array}$ & $\left.\begin{array}{l}1.73 \\
1.75 \\
1.75\end{array}\right\}$ & \}$_{19}^{60}$ & $\begin{array}{l}\text { Hoblinsun coke } \\
\text { Therm.1x }\end{array}$ & $\begin{array}{l}32.5 \\
32.5 \\
32.5\end{array}$ & $\begin{array}{l}\text { Petrux: ion } \\
\text { Pextrusion } \\
\text { Extrualon }\end{array}$ & in covered grapilite iray \\
\hline $\begin{array}{l}2 A \\
28\end{array}$ & $\begin{array}{l}\text { CAC } \\
\text { GAC }\end{array}$ & $\begin{array}{l}0.490 \\
0.490\end{array}$ & & $\begin{array}{l}1.0 \\
1.0\end{array}$ & $\begin{array}{l}43 \\
40\end{array}$ & $\begin{array}{l}\text { log9 graphitto } \\
1089 \text { graphite. }\end{array}$ & $\begin{array}{l}55-58 \\
35-58\end{array}$ & $\begin{array}{l}\text { Adm } 1 x \\
\text { Adm }: x\end{array}$ & $\begin{array}{l}\text { li, tube }(H-327) \\
\text { lis eube }(H-32 i)\end{array}$ \\
\hline $2 \mathrm{C}$ & $\therefore A C$ & 0.490 & & 1.0 & $\int_{40}^{10}$ & $\begin{array}{l}\text { Thurmax } \\
\text { RC.4 kr.tphite. }\end{array}$ & $55-58$ & $\operatorname{Ad} d x$ & In evibe $(1-327)$ \\
\hline $\begin{array}{l}3 n \\
30 \\
30 \\
30\end{array}$ & $\begin{array}{l}\text { ORVL. } \\
\text { ONNL. } \\
\text { JRNL. } \\
\text { ONNL. }\end{array}$ & $\begin{array}{l}0.490 \\
n .440 \\
0.490 \\
0.490\end{array}$ & & $\begin{array}{l}1.0 \\
1.0 \\
1.0 \\
1.0\end{array}$ & $\begin{array}{l}29.6 \\
38.7 \\
38.7 \\
41.1\end{array}$ & 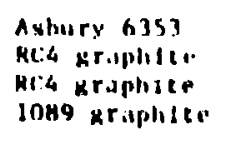 & $\begin{array}{l}60-62 \\
60-2 \\
60 \rightarrow 2 \\
60-62\end{array}$ & $\begin{array}{l}\text { Slug infection } \\
\text { slug injection } \\
\text { slug injection } \\
\text { slug injection }\end{array}$ & $\begin{array}{l}\text { In parked aluminu } \\
\text { In packed alunina } \\
\text { In blork (H-327) } \\
\text { In block (H-i27) }\end{array}$ \\
\hline $\begin{array}{ll}4 A \\
\text { in }\end{array}$ & $\begin{array}{l}\text { CAC } \\
\text { CAAC }\end{array}$ & $\begin{array}{l}0.490 \\
0.490\end{array}$ & & $\begin{array}{l}1.0 \\
1.0\end{array}$ & $\begin{array}{l}40 \\
40\end{array}$ & $\begin{array}{l}1089 \text { kriplidlo } \\
\text { JO89 ariphilla" }\end{array}$ & $\begin{array}{l}55-58 \\
55-58\end{array}$ & $\begin{array}{l}\operatorname{Adm} 1 x \\
\operatorname{Adm} 1 x\end{array}$ & $\begin{array}{l}\text { In eube }(H-327) \\
\text { In cube }(H-327)\end{array}$ \\
\hline $4 c$ & CAC & 0.490 & & 1.0 & $\left\{\begin{array}{l}10 \\
40\end{array}\right.$ & $\begin{array}{l}\text { Thie rmiax } \\
\text { RC4 x rasplite: }\end{array}$ & $58-58$ & Admix & In (whe $(H-327)$ \\
\hline
\end{tabular}

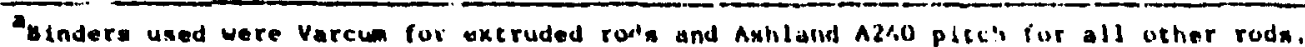

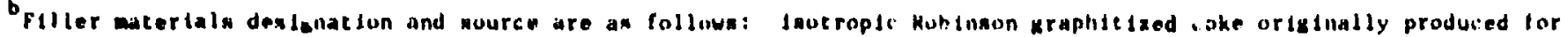

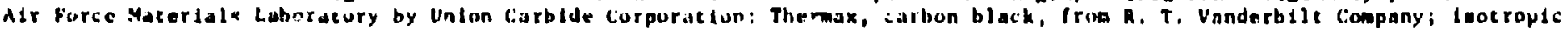

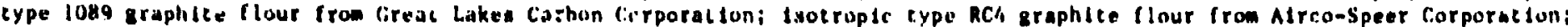
and anlet rople eype isbury naeural flake graphlte 6353 from Asbury Giraphile Mills. Inc. 
The fillers selected fur the slug-injected specinens consisted of two of the GAC experinental waterials and the GAC reference grade NF 6353 natural flake graphite powder. Ashland grade A240 pitch was used in all these specinens as binder.

During fabrication of the slug-injection-bonded fuel rods, special precautions were required to obtain a satisfactory blend of the four types of coated particles. A decade splitter was used to divide the particles required for a single fuel rod into ten equal portions, each portion containing all types of particles. These portions vere then transferred to the mold with a probe to ninimize free fall of the particles and avoid segregation. Radiographs of fuel rods prepazed in this manner showed quite uniform loadings (see Fig. 5). All the matrix materials were injected into the particle beds without difficulty at $180^{\circ} \mathrm{C}$ and $1000 \mathrm{psi}$. Two carbonization modes were used: positioned vert.cally in a packed bed of alumina or positioned horizontally in an H-327 graphite tube. The specimens were given a final heat treatment of $1800^{\circ} \mathrm{C}$. Matrix densities and pitch coke yields of slug-injected specinens were highest for thuse carbonized in graphite tubes.

All specimens for the experiments were characterized by photography, radiography, metallography, weights, measurenents, fuel loadings, and, in the case of the slug-injected-bonded specimens, by pitch coke yield. Data sumaries of these characterizations are given in Table 5.

Table 5. Physical Characteristics of Specimens for HRB-4 and -5

\begin{tabular}{|c|c|c|c|c|c|c|c|}
\hline \multirow{2}{*}{$\begin{array}{l}\text { Spectnea } \\
\text { tuber }\end{array}$} & \multirow{2}{*}{$\begin{array}{l}\text { Position } \\
\text { In } \\
\text { Capsule }\end{array}$} & \multicolumn{2}{|c|}{ Average Diancer, in. } & \multirow{2}{*}{$\begin{array}{l}\text { Average } \\
\text { Lengeh } \\
\text { (in.) }\end{array}$} & \multirow{2}{*}{$\begin{array}{l}\text { Particle } \\
\text { Volue } \\
\text { Losding ( })\end{array}$} & \multirow{2}{*}{$\begin{array}{l}\text { Matrix } \\
\text { Densicy } \\
\left(8 / \infty^{\prime}\right)\end{array}$} & \multirow{2}{*}{$\begin{array}{l}\text { Piech } \\
\text { Coke } \\
\text { rield (z) }\end{array}$} \\
\hline & & Outside & Inside & & & & \\
\hline \multicolumn{8}{|c|}{ Capeule nn-4 } \\
\hline$J I-11-9$ & $\mathbf{1 A}$ & 0.4890 & 0.0910 & 1.740 & 30.6 & 1.60 & \\
\hline JI-11-3 & 18 & 0.4912 & 0.0905 & 1.743 & 31.3 & 1.69 & \\
\hline$J 1-11-5$ & $1 C$ & 0.4904 & 0.0910 & 1.758 & 31.3 & 1.70 & \\
\hline $\mathrm{mS4h002}$ & 34 & 0.4901 & & 0.953 & 61.0 & 0.550 & 18.7 \\
\hline 10864025 & 38 & 0.4899 & & 0.953 & 61.0 & 0.733 & 25.0 \\
\hline 106031 & $3 \mathbf{C}$ & 0.4916 & & 0.938 & 61.6 & 0.846 & 38.0 \\
\hline $\operatorname{mos} n 002$ & 30 & 0.4916 & & 0.956 & 60.4 & 0.840 & 35.8 \\
\hline \multicolumn{8}{|c|}{ Capoule ins-5 } \\
\hline$J I-11-10$ & $\mathbf{u}$ & 0.4890 & 0.0905 & 1.747 & 30.7 & 1.61 & \\
\hline$J I-11-16$ & 18 & 0.6903 & 0.0905 & 1.746 & 31.1 & 1.64 & \\
\hline$J 1-11-4$ & $1 \mathrm{C}$ & 0.4909 & 0.0905 & 1.744 & 31.3 & 1.69 & \\
\hline M85A004 & $3 \mathbf{A}$ & 0.4899 & & 0.949 & 61.3 & 0.557 & 19.3 \\
\hline M86AC26 & 38 & 0.4904 & & 0.953 & 60.9 & 0.750 & 26.0 \\
\hline M861032 & $3 c$ & 0.4907 & & 0.952 & 60.9 & 0.847 & 39.2 \\
\hline M95A007 & 30 & 0.4911 & & 0.956 & 60.6 & 0.854 & 38.4 \\
\hline
\end{tabular}


It should be noted that in metallographic exanination of specimens, matrix-particle interaction occurred in some of the slug-injection-bonded specinens that were carbonized in-tube, resulting in a soall tear at the outer edge of the coating. Examples of ihis are shown later in the report. In sone of the fissfle partfcles contained in unirradiated extrusions, fire cracking of the silicon carbide occlired even though the buffer and outer low-temperatire isotropic (LII) coatings vere not damaged. These phenomena in both types of specimens could only be seen at high magnifications.

\section{DESCRIPTION OF IRRADIATIOA}

\section{Irradiation Conditions}

Both capsules were inserted into the HFIR on October 9, 1972. HRB-4 was placed in the RB-7 facility, and HRB-5 was placed in the RB-5 facility. The locations of these facilities within the HFIR, and the neutron flux and gatation heating characteristics of the facilities have been described previously.

\section{Capsule Operation}

Both capsules were inserted at the beginning of HFIR cycle 83 . The HRB-4 opera'ing history is given in Table 6 . This capsule was irradiated for 11 HFIR cycles and was removed from the reactor on June 26,1973 . HRB-5 begar operation at the sane the as BRB-4, but was operated for only five cycles, so the influence of burnup and neutron exposure on perfornance could be deternined. It was renoved at the end of cycle 87, on February 3, 1973.

The operation of both capsules vas stable throughout irradiation. There was an initial drop in the power production from the fuel spectens as the ${ }^{235} \mathrm{U}$ was burned out. This cirop was expected. To compeasate for the consumptior. of ${ }^{235} \mathrm{U}$, the ${ }^{232} \mathrm{Th}$ and $23{ }^{\mathrm{U}} \mathrm{U}$ contents of each specinen were adjusted so that fissile ${ }^{233} \mathrm{U}$ and ${ }^{239} \mathrm{Pu}$ bred in by neutron capture would provide continuing fission power with a efnimum of power variation with time. The fission heat rates vs time for each fuel spectuen adjacent to a graphite thermocouple are presented in Fis. 6.

The neutron fluxes and fluences are presented in Tables 7 and 8 for each fuel specinen. Also shown in these tables are the calculated isotropic burnups for each specinen, which are based on the neutron fluxes given. The helfum-neon sweep gas effluent was sampled periodically to measure fission gas release. The rat $10 s$ of release rate to birth rate

${ }^{7}$ F. J. Howan et al., Imradiation Performance of HTCR Puel Rods in HFIR Experiment HRB-3 anä ETR Experiment P13N, ORWL-TH-4526 (October 1974). 
Table 6. Capsule BRs-4 Operating History

\begin{tabular}{|c|c|c|c|c|}
\hline \multirow{2}{*}{$\begin{array}{l}\text { HPIR } \\
\text { Cycle }\end{array}$} & \multicolumn{2}{|c|}{ Cycle } & \multirow{2}{*}{$\begin{array}{c}\text { Days } \\
\text { Operation }\end{array}$} & \multirow{2}{*}{$\begin{array}{c}\text { Accuslated } \\
\text { Irradiation Tine } \\
\text { at } 100 \text { Md Reactor } \\
\text { Power } \\
\text { (hr) }\end{array}$} \\
\hline & Begin & End & & \\
\hline $\begin{array}{l}83 \\
84 A \\
84 \mathrm{~B} \\
85 \\
86^{\mathrm{a}} \\
87 \mathrm{~A} \\
87 \mathrm{~B} \\
88 \\
89 \\
90 \\
91 \\
92^{\mathrm{b}} \\
93\end{array}$ & $\begin{array}{l}10 / 8 / 72 \\
10 / 24 / 72 \\
11 / 13 / 72 \\
11 / 20 / 72 \\
12 / 13 / 72 \\
1 / 9 / 73 \\
1 / 12 / 73 \\
2 / 3 / 73 \\
2 / 27 / 73 \\
3 / 23 / 73 \\
4 / 18 / 73 \\
5 / 11 / 73 \\
6 / 3 / 73\end{array}$ & $\begin{array}{l}10 / 23 / 72 \\
11 / 11 / 72 \\
11 / 19 / 72 \\
12 / 13 / 72 \\
1 / 7 / 73 \\
1 / 10 / 73 \\
2 / 3 / 73 \\
2 / 26 / 73 \\
3 / 22 / 73 \\
4 / 15 / 73 \\
5 / 11 / 73 \\
6 / 3 / 73 \\
6 / 26 / 73\end{array}$ & $\begin{array}{r}15 \\
18 \\
5 \\
23 \\
24 \\
1 \\
21 \\
23 \\
23 \\
23 \\
23 \\
23 \\
23\end{array}$ & $\begin{array}{r}364.3 \\
925.2 \\
1479.4 \\
2037.6 \\
\\
2577.8 \\
3119.0 \\
3664.5 \\
4213.4 \\
4764.2 \\
5310.1 \\
5854.8\end{array}$ \\
\hline
\end{tabular}

Includes two days at $50 \mathrm{mH}$.

bithin the first three days of this cycle the reactor experienced five enentary power reductions. 

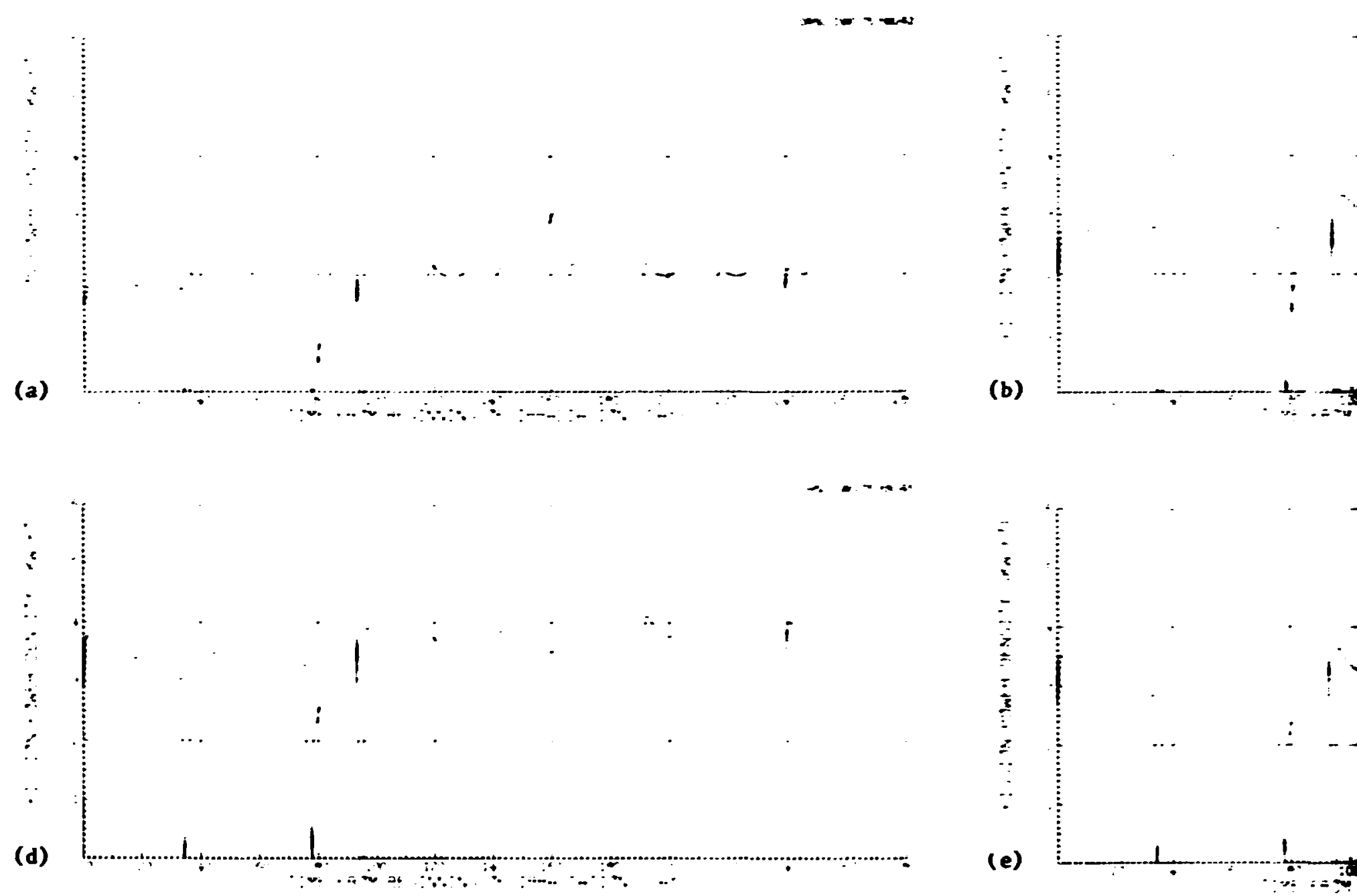

F18. 6. Fission Heat Rate us Time for HRB-4

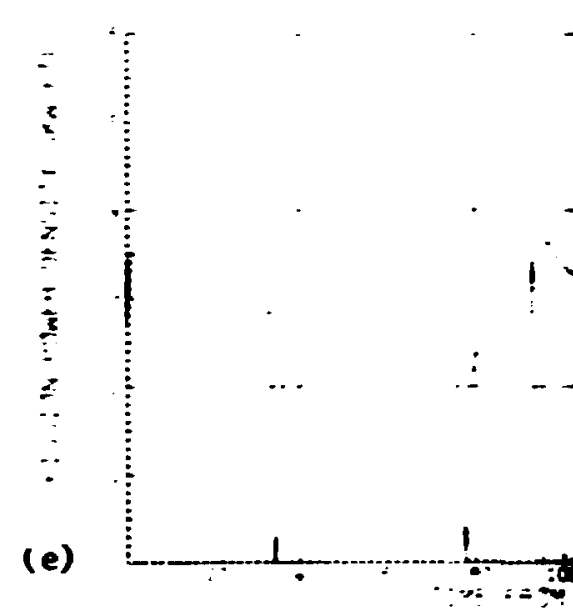




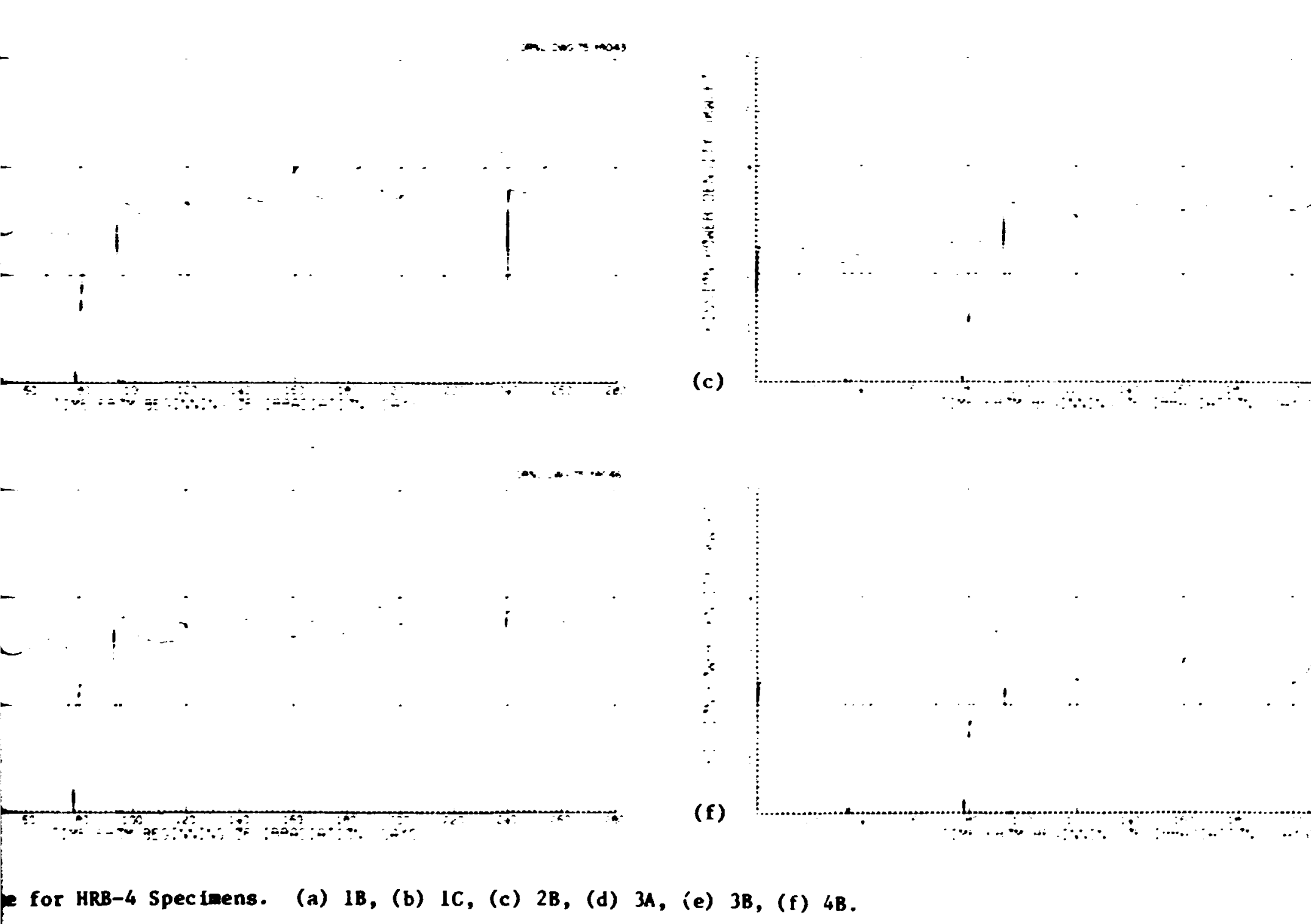



3 


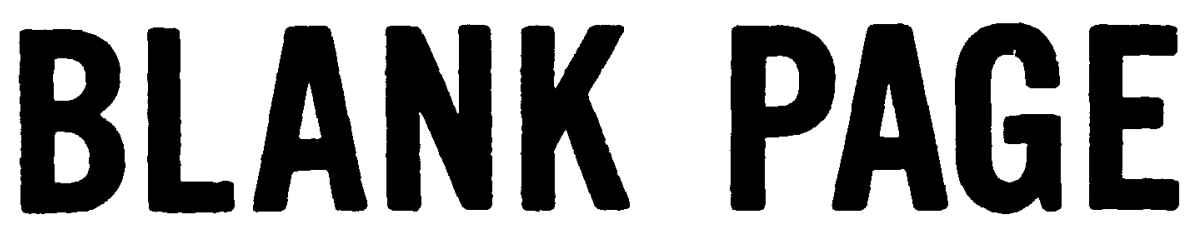



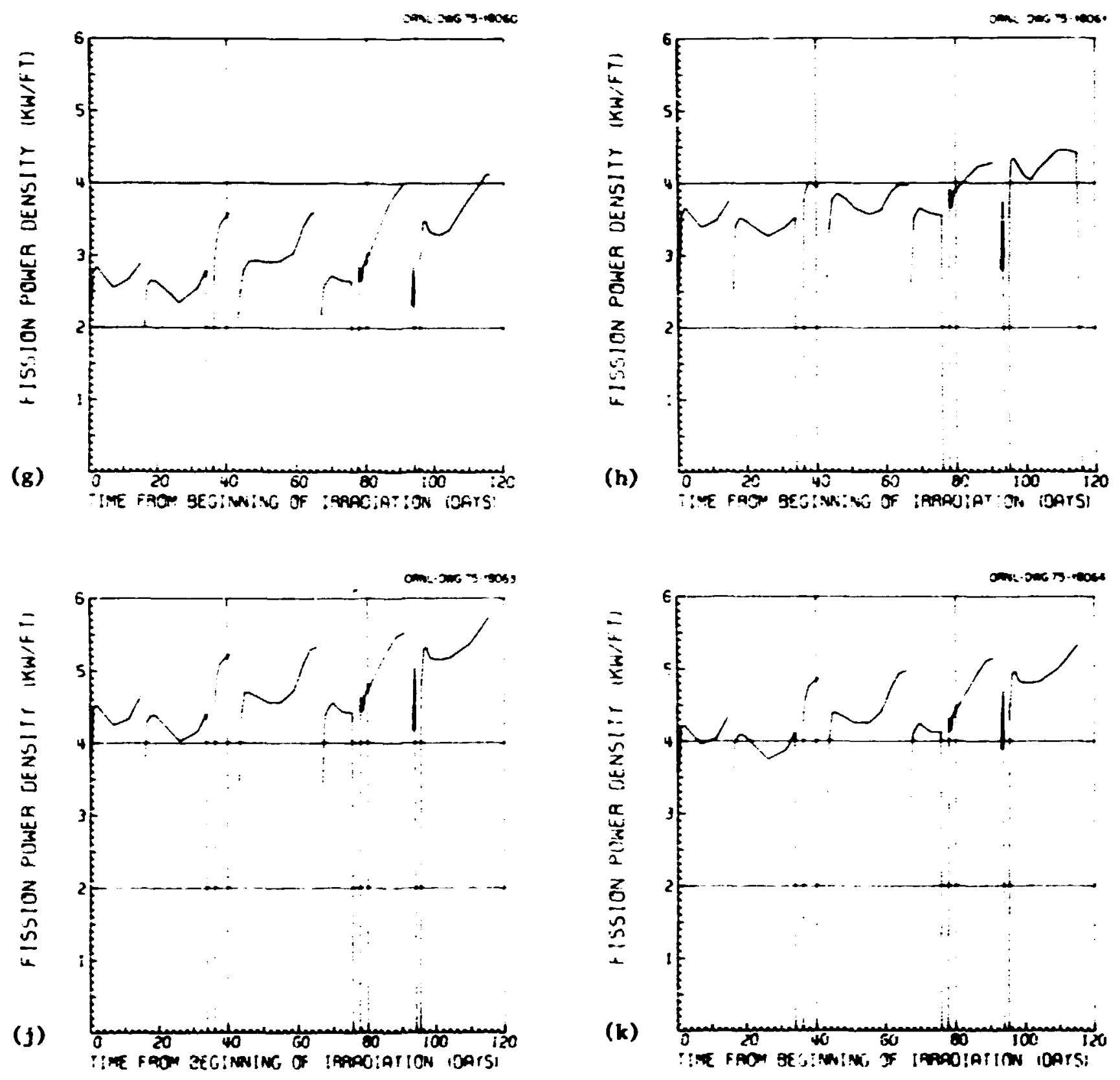

Fig. 6. (Continued) Fission Heat Rate vs Time for HRB-5 Specimens. (g) 1B, (h) 1C, (i) 


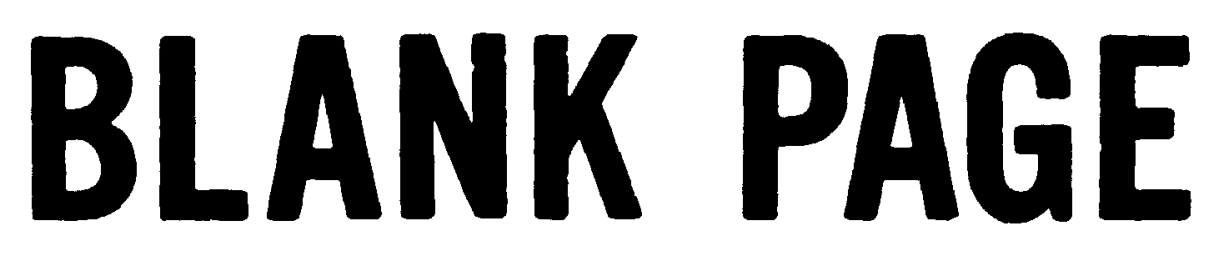

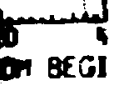

|

(j) 3 
Table 7. HRB-4 Fuel Specimen Burnups and Neutron Exposures

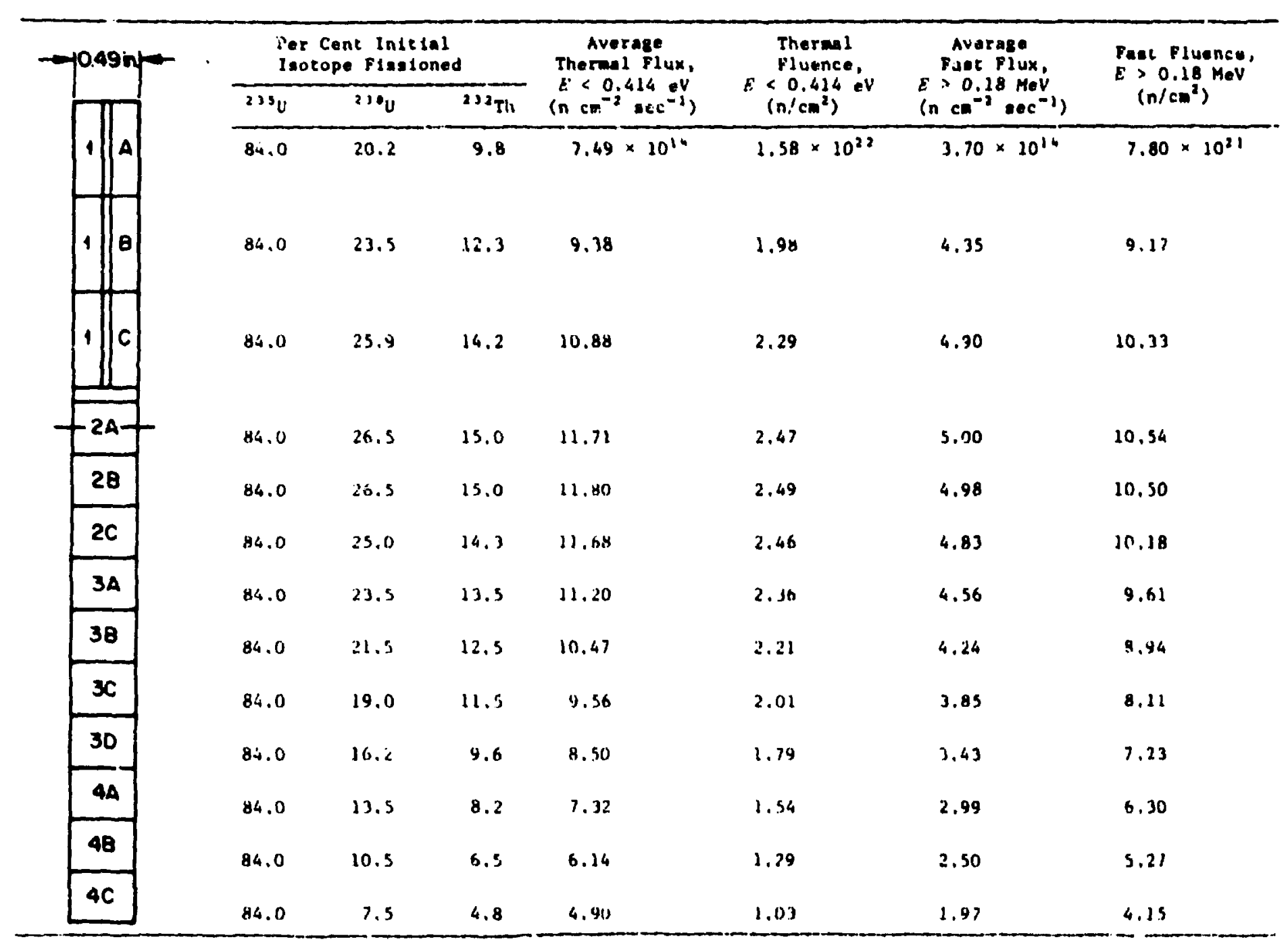


Table 8. HRB-5 Fuel Specinen Burnups and Neutron Exposures

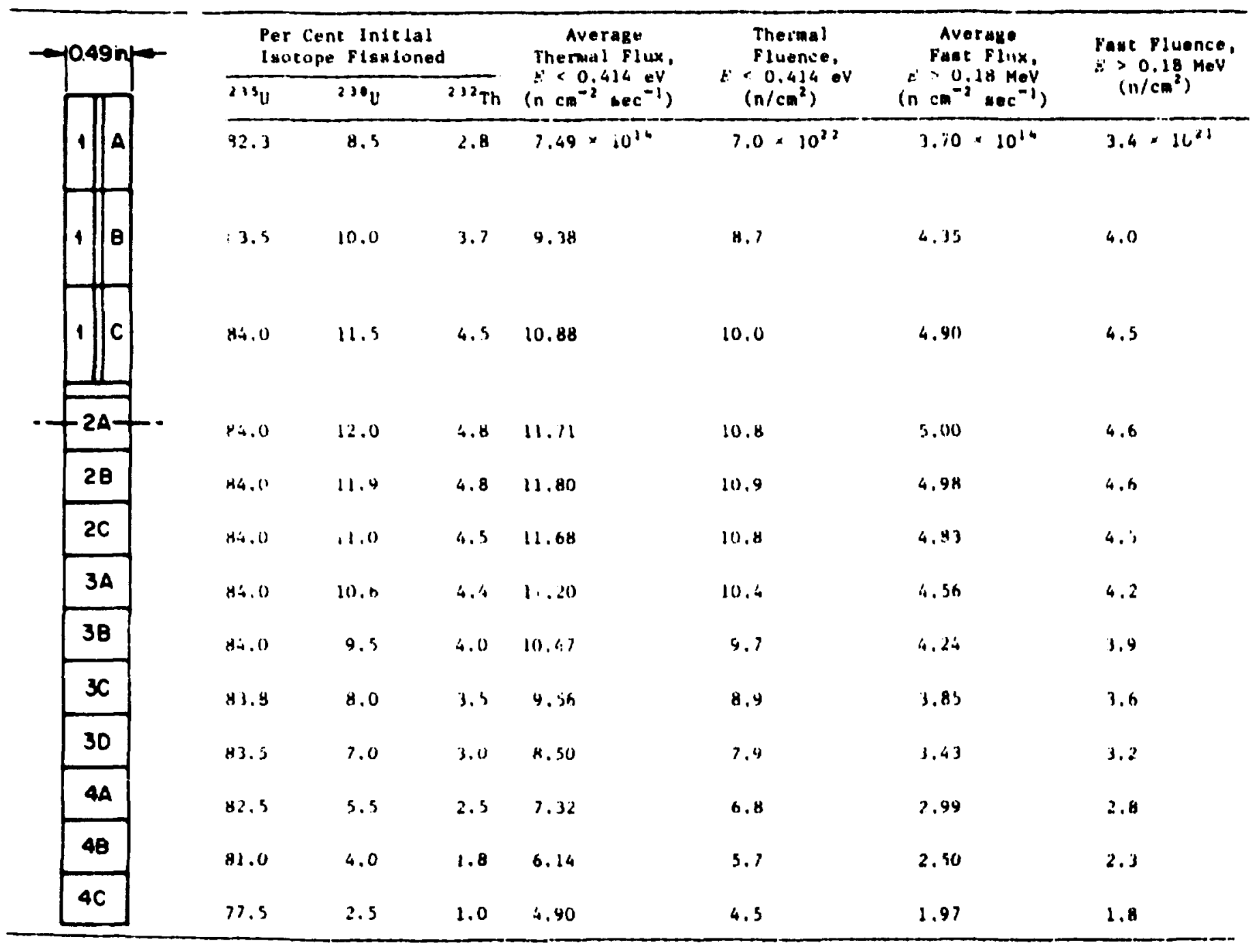


( $: / B)$ for seiected isotopes vs accumulated irradiation time are shown in Tables 9 and 10 and are pincted in Figs. 7 and 8 . The birth rates used in this calculation take into account the depletion of ${ }^{235} \mathrm{U}$ and fissions of bred-in ${ }^{23} \mathrm{U}$ and ${ }^{239} \mathrm{Pu}$. The daily change in isotopic composition for each fuel rod is calculated, and then the fission product yield from each fissionable isotope.

\section{Operating Temperatures}

Capsules HRB-4 anc -5 contained eight Chromel-Alumel therwocouples in the graphite sieeves and one centerline thermoneter in specinen 1C. As indicated earlier, no useful data vere obtained from the centerline thermometers because of the severe decalibration. Ef forts are still under way to understand the decalibratior kinetics of these devices, and the results of these efforts vill be published at a latar date.

atterpts have been ade to directly calculate the operating temperatures of HRB capsules. The calculated and measured graphite midwall teaperatures were used as a check on the accuracy of the calculation. This procedure yielded good comparisons in sume cases and poor comparisons in others. There are numerous uncertainties which frustrate such attempts: (1) exact gara heating rates for the aterials involved as a function of time and axial location, (2) exact neutron fluxes and cross-secticn values, (3) knowledge of the time variation of the neutron flux as a function of axial position. This last item is tine nost uncertain. The shape of the curve for flux is time is known only at the reactor horizontal midplane. Flux mapping and gama heat ing expeziments ace under way in tile HFIR, but in the meantime we have developed an alternate procedure fur calculating specimen operating temperatures. Thi.j procedure is out! ined in detail in Ref 8 and will not be described he:e, except to say that mathenatical models 9,10 are used to determine the specimeri $f$ ission heat generation rate by forcing the calculated graphite centerline temperature to match the measured temperature. Then, using the calculated fission heat rates in corjunction with sweep gas compositions, the fuel surface and center temperatures are calculated. During irradiation the sweep gas compositions are measired by flow meters. These cata are improved through the use of the models and force fitting measured and calculated graphite midwall cemperatures. This method has worked very well and has the added advantage of a built-in corrector to compensate for uncertainties. This is explained in Ref. 8.

${ }^{8}$ F. J. Homin et al., Thermal Analysis of HTGP Fue? Rods Irradiated in the HFIR Remouxble Beryllium Facility, ORNL/TM Report (in preparation).

${ }^{9} \mathrm{~F}$. J. Homan et al., HTRANS - A FORTKAN IV Computer Prograon for Thermal Analysis of Coated Particle Fuels, ORNL/TM Report (in preparation).

${ }^{10}$ K. H. Valentine, ENCTRK, A Computer Progran to Model Heat Transfer Across Asymmetric Capz in Cylindrical Fuel Rods, ORNL/TM Report (in preparation). 


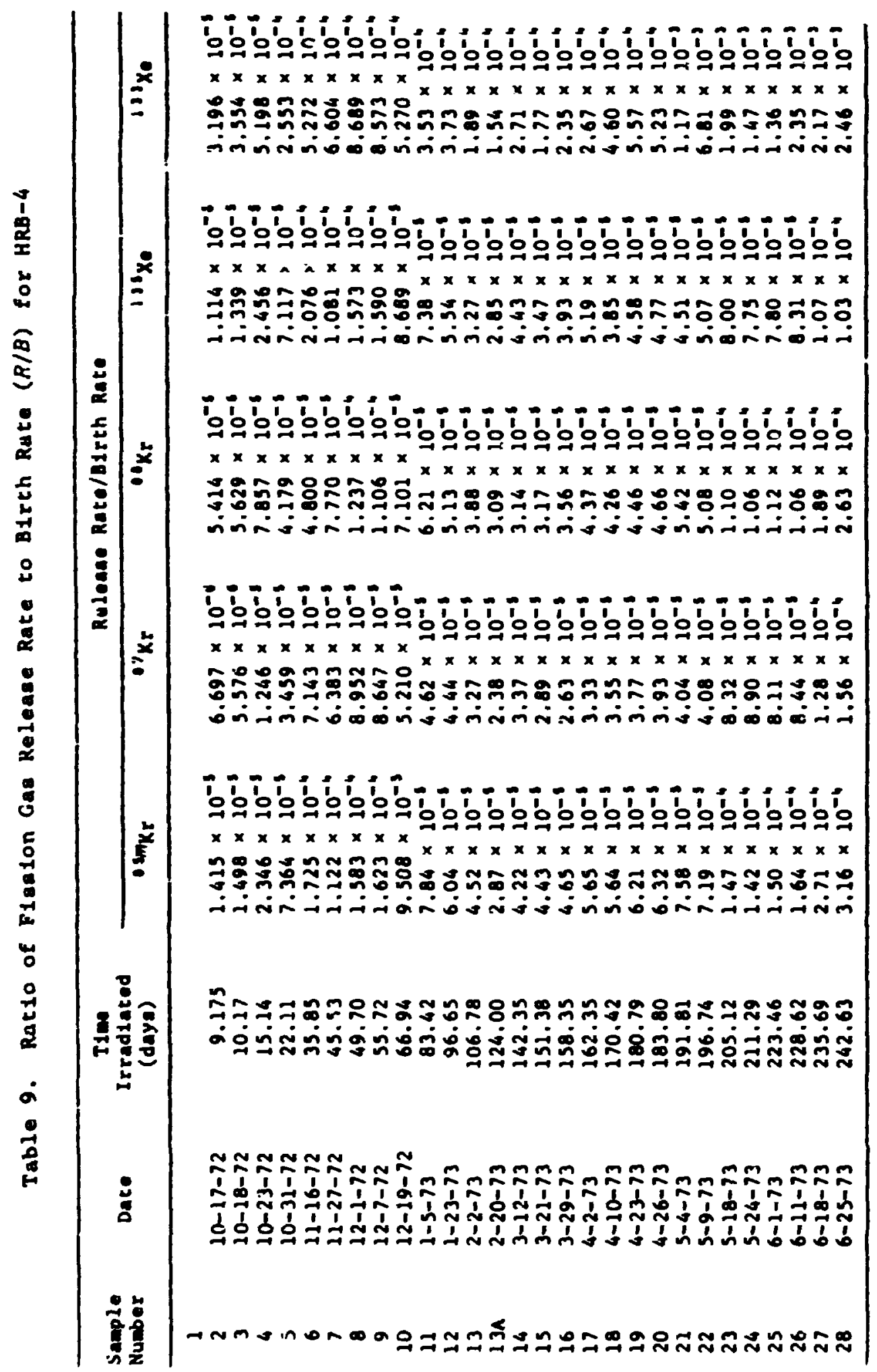




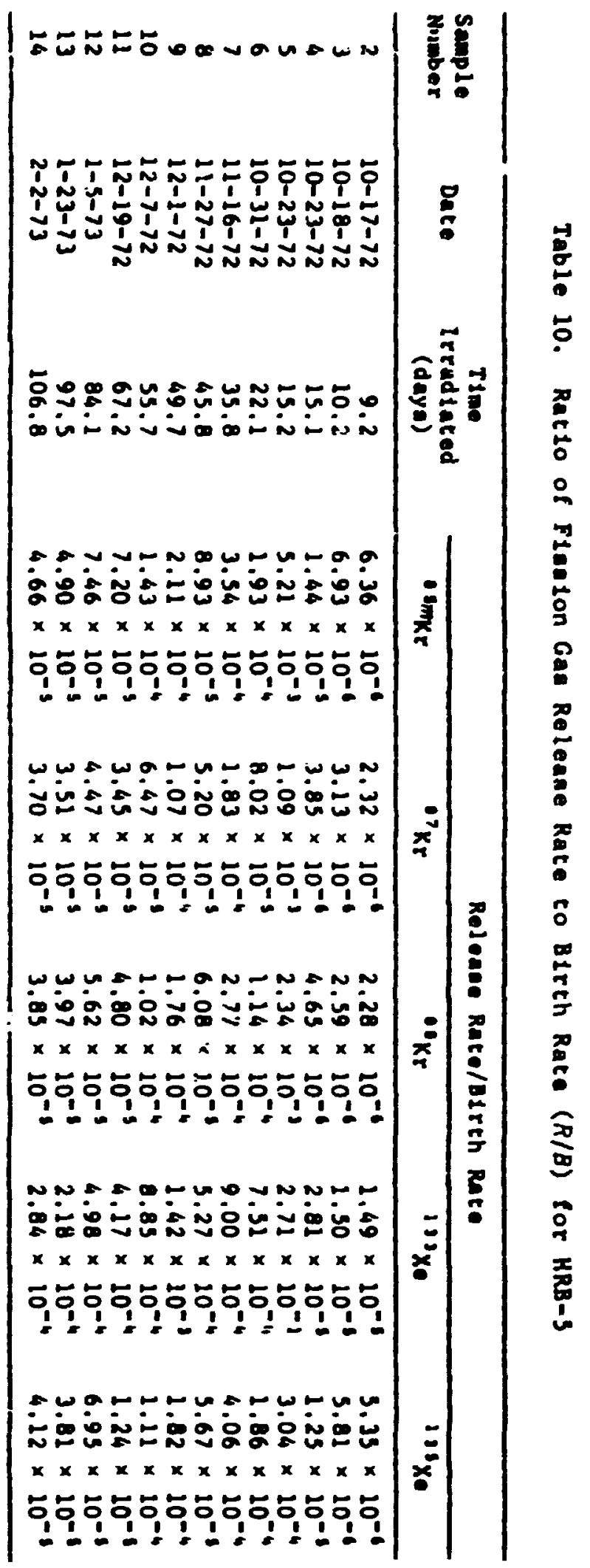




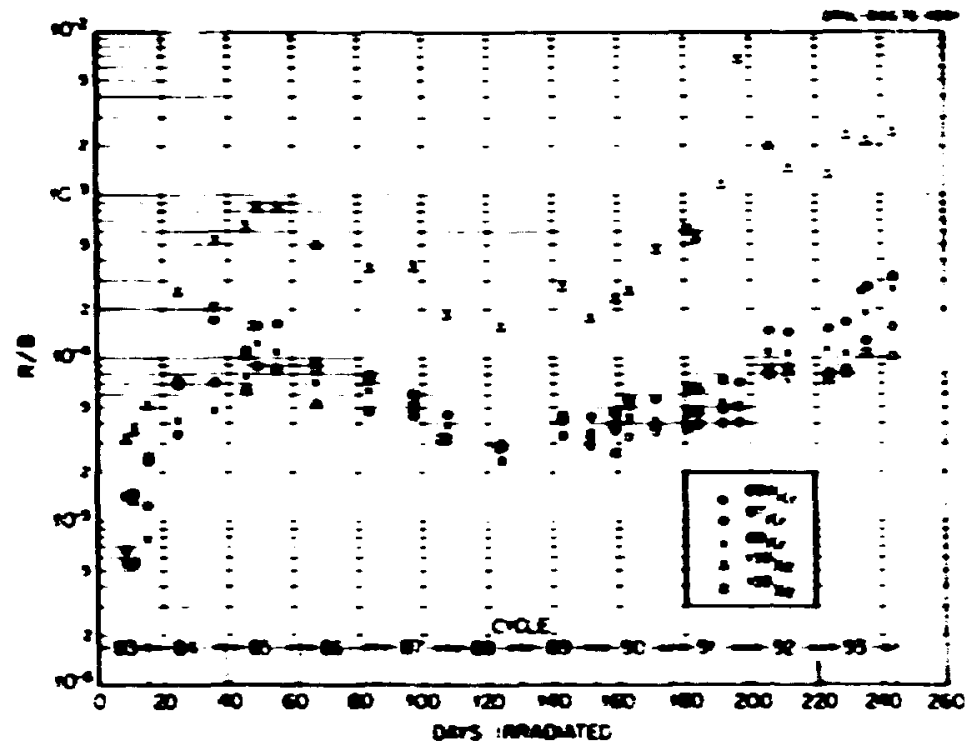

Fig. 7. HFTR Heb-4 Experinent Fission Gas Saple Data.

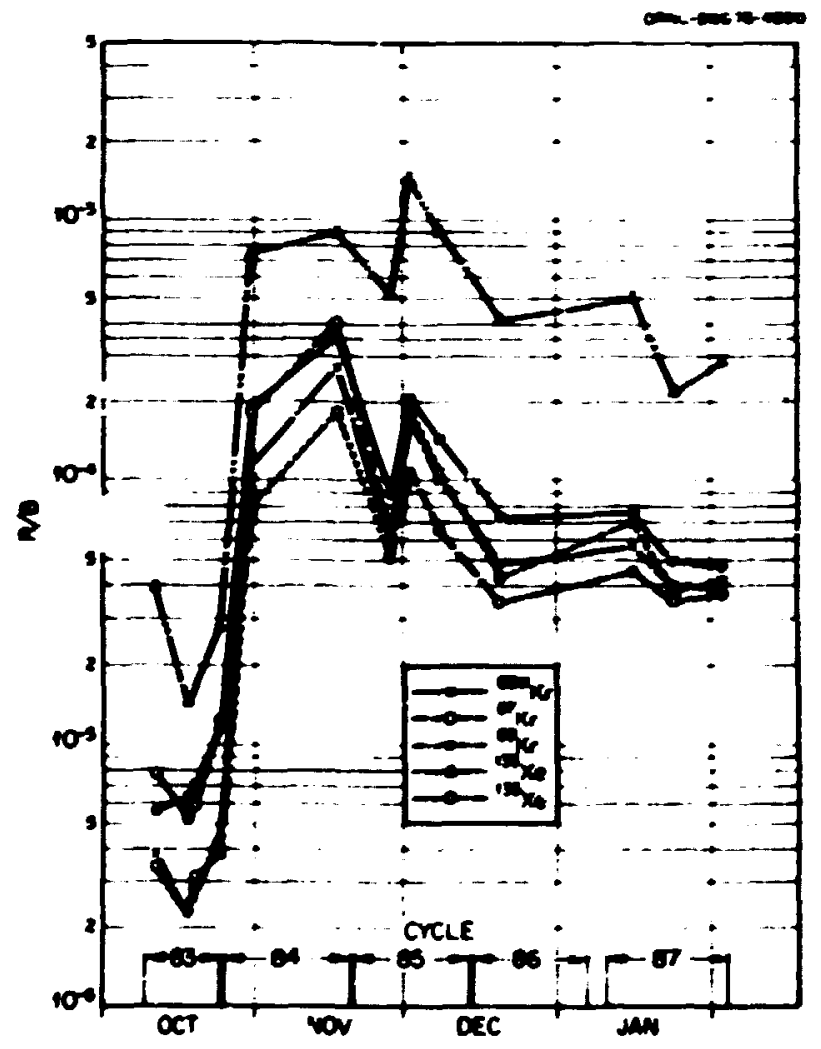

F18. 8. HFIR HRB-5 Capsule Fission Gas Sample Data. 
The calculated graphice aiduall, fuel surface, and fuel center cemperacures for the Hes -4 and -5 capsules are given in Fig. 9. Although not labeled explicitly, the uppermst curves of Fig. 9 are alvays fuel centerline temperatures, and the lowernost are always graphite aiduall temperatures. As was the case with the fission heat rates shom in Fig. 6, only fuel temeratures adjacent to graphite aidull thernocouples are presented.

\title{
POSTIRRADIATIOA EXNMIMTIOA ATD AMALYSIS
}

\section{Disassembly and Physical Exanination}

\begin{abstract}
Visual examation of the exterior surfaces of cafsules lans-4 and -5 revealed no unusual or unexpected features. Gana scans $(0.55-0.75 \mathrm{heV})$ made along the lengths of the capsules shored the fuel rods to be intact, with no gross segregation of fuel within the fuel rods or accunulation of fission products at the ends of the fuel coluns. The graphite sleeves which contained the fuel rods were removed from the primary containent after cutting of the botton and top of the capsules. The fuel rods were removed from the graphite sleeves. Fuvil rods $2 \mathrm{~A}, 2 \mathrm{~B}, 2 \mathrm{C}$, 4A, 4B, 4C, and 4D were visually exanined and dimensionally inspected by a CAC reprerantative; arrangenents were made to return the Gac fuel rods to the ir bo cells for detalled exaninations.

The extruded fuel rods ( $1 A, 1 B$, and 1C) from HRB-4 and -5 were in excellent condition, as shown in Figs. 10-12. The appearance of the slug-injected rods $3 A, 3 B, 3 C$, and $3 D$ from HBB-4 and -5 is sinown in Figs. 13-16. The slug-injected rods from HRb-5 were in excellent condition. The following coments pertain to the slug-injected fuel rods from HRB-4, the higher fluence capsule. Fuel rod 34 was in good condition, with only slight debonding noted on the cop and botcon edges. Although no failures were seen on the outer surface of rod 34 , a sooty region was noted on the botton end of the rod that indicated a failure had occurred. Rod 38 was badly debonded in two regions at the top of the rod; stereo examination revealed only one failed particle on the surface of the rod. A rather large sooty region was noted on one side of fuel rod 3 in a partially debonded zegion; stereo exanination revealed that numerous outer LTI layers had failed, exposing SiC layers on the side, top, and botton surfaces of the fuel rod. Fuel rod 3D was in excellent condition; stereo examination revealed only one sooty region and that occurred on the top of the rod.
\end{abstract}

\section{Dinensional Changes}

The correlation of fuel rod dimensional change with fast fluence (>0.18 MeV) is show in Fig. 17. As stated earlfer, these fuel rods contained Biso- and Triso-coated particles; the particle volue loading is 60-62z for the slug-injected rods and about $30 \%$ for the extruded rods. 



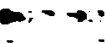

2.

-

i

-

i

$-$

5
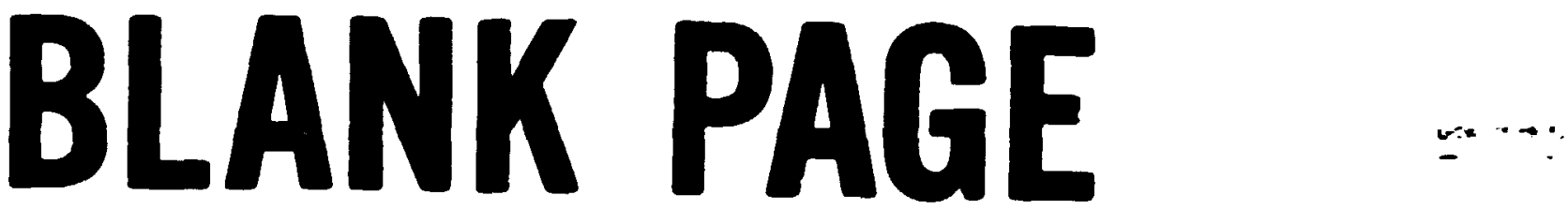

1

$-$

$\therefore$

$\therefore$

- 
$m$

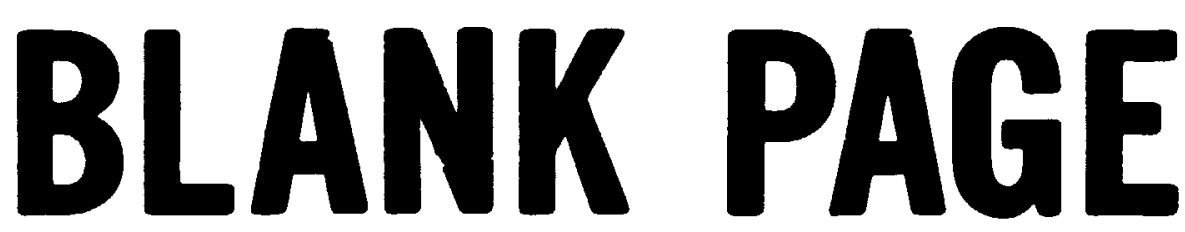

-

-

c.

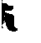

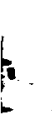

x

BLANK PAGE 
24
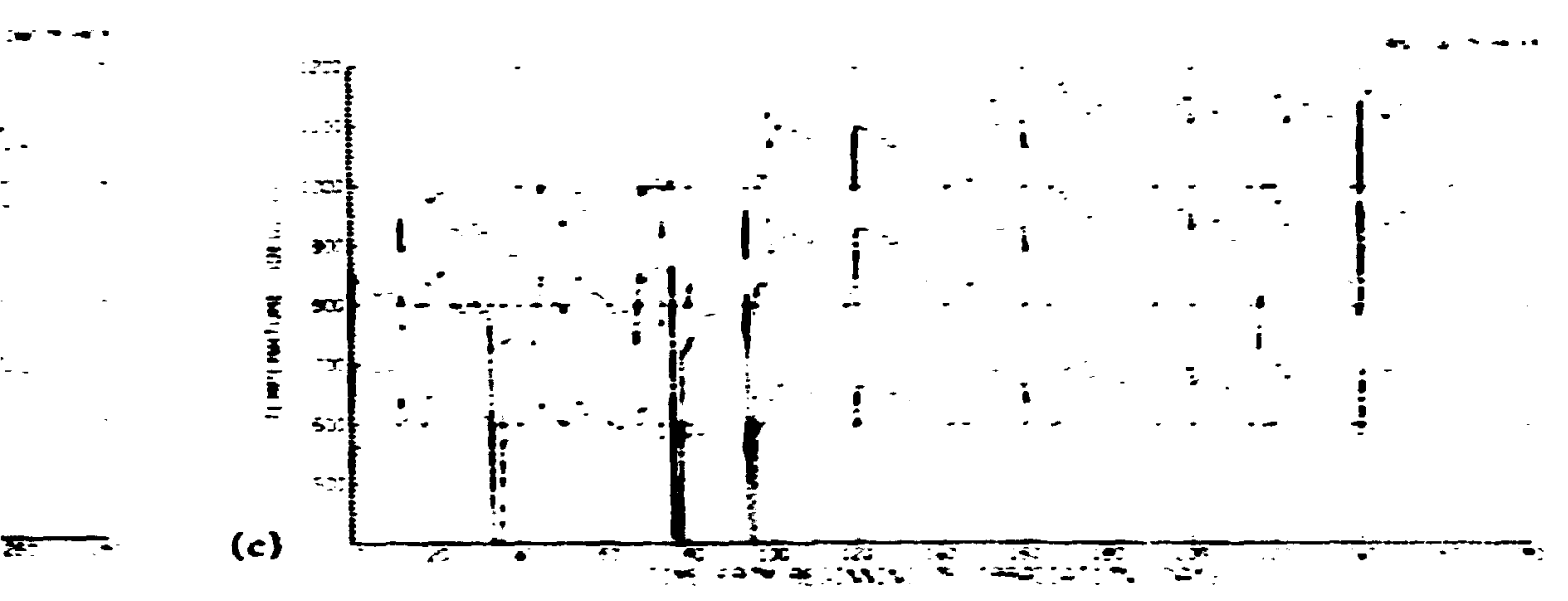

(c)

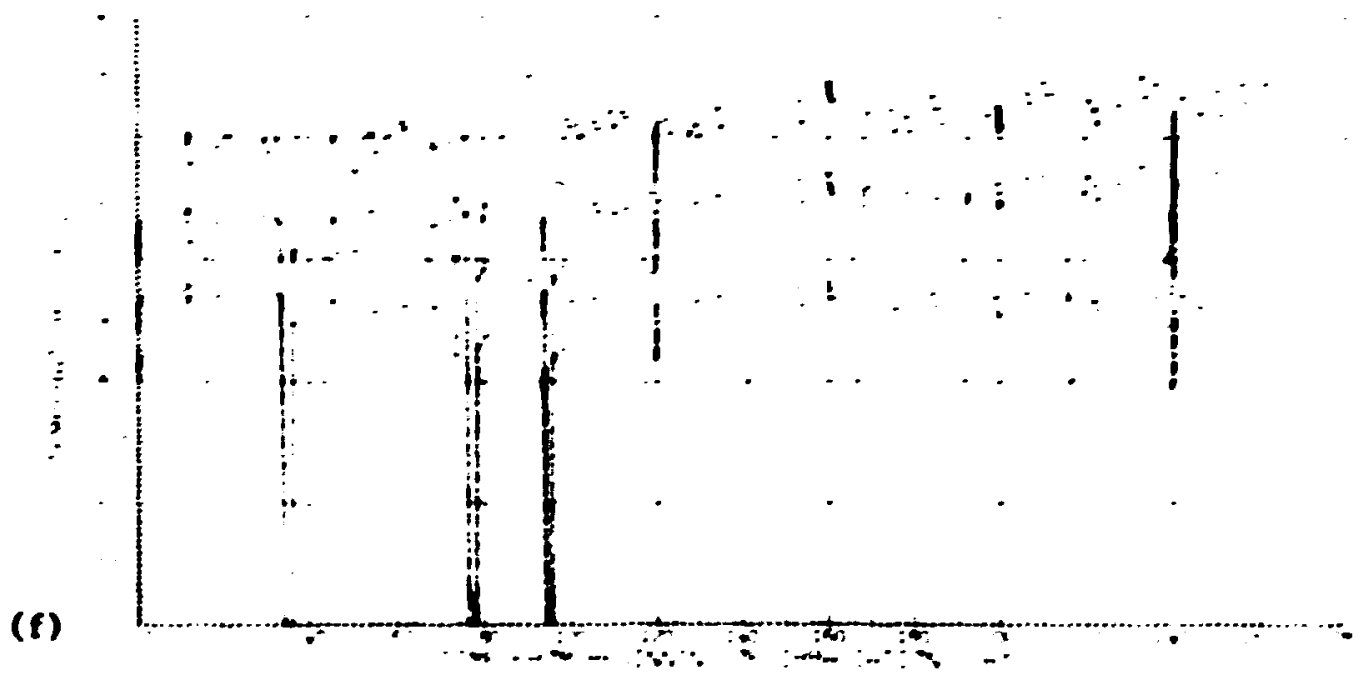

(b) $1 C$, , (c) 28, (d) $3 A$, (e) 38, (f) $4 B$. 

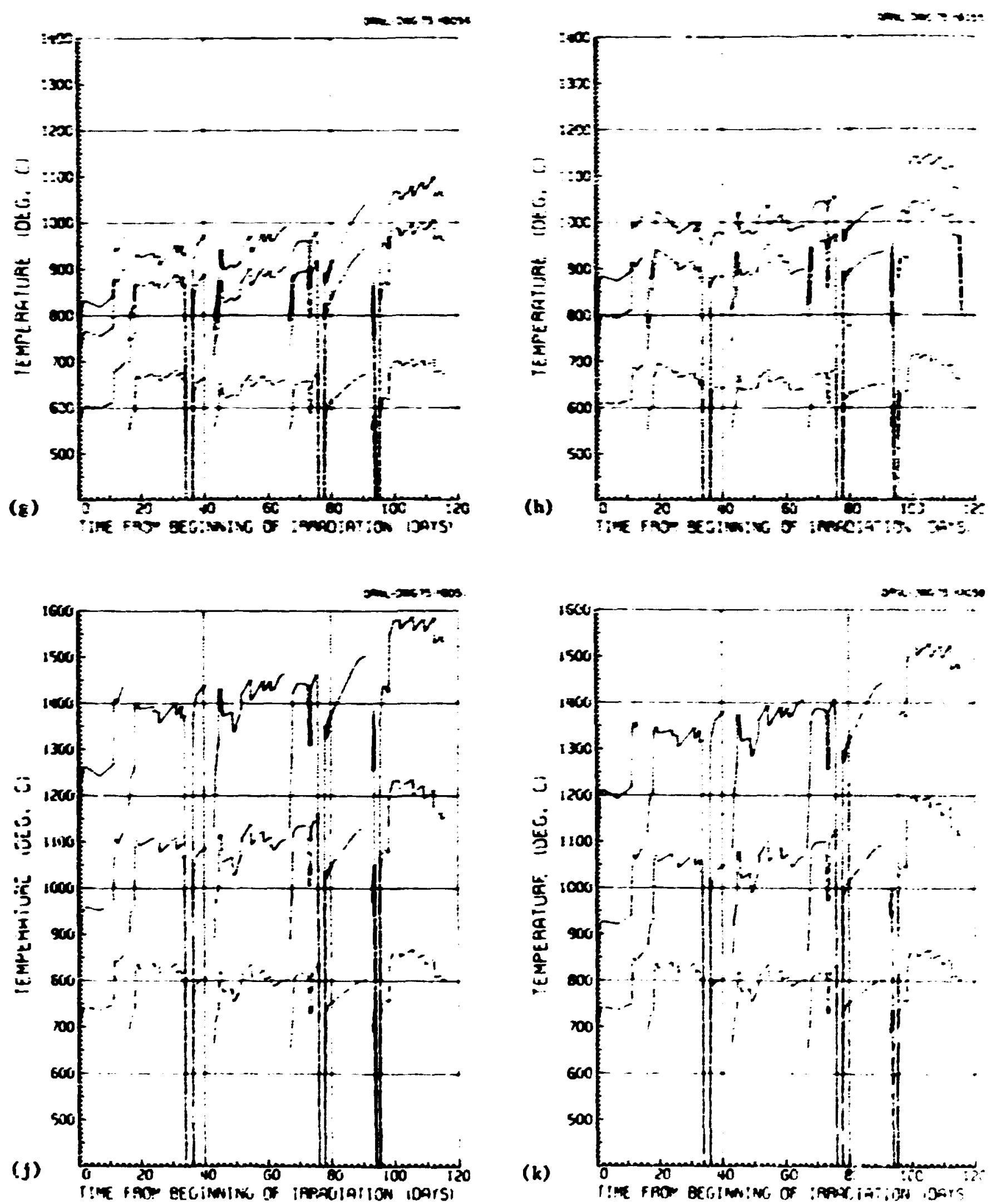

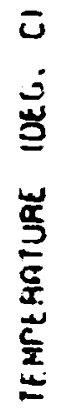




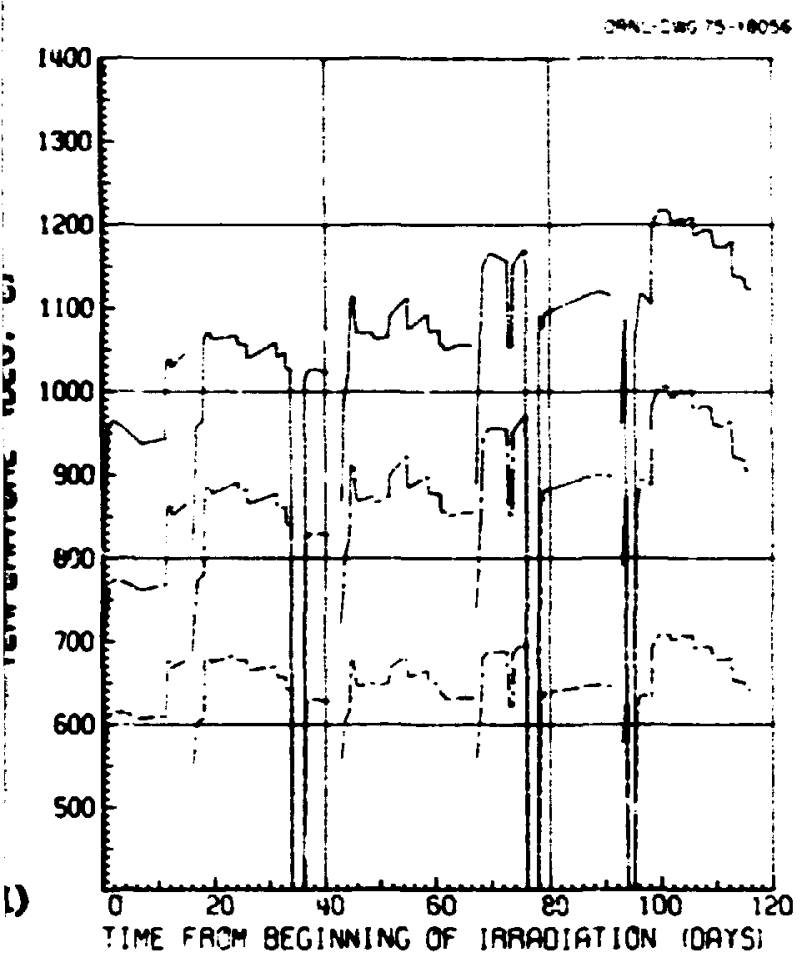

Fig. 9. (Continued) Graphite Midwall, Fuel Surface, an Center Temperatures for HRB-5 Specimens. (B) 1B, (h) 1C, (i) (j) $3 \mathrm{~A}$, (k) $3 \mathrm{~B}$, (1) $4 \mathrm{~B}$.

OAnL-0w6 7s-18059

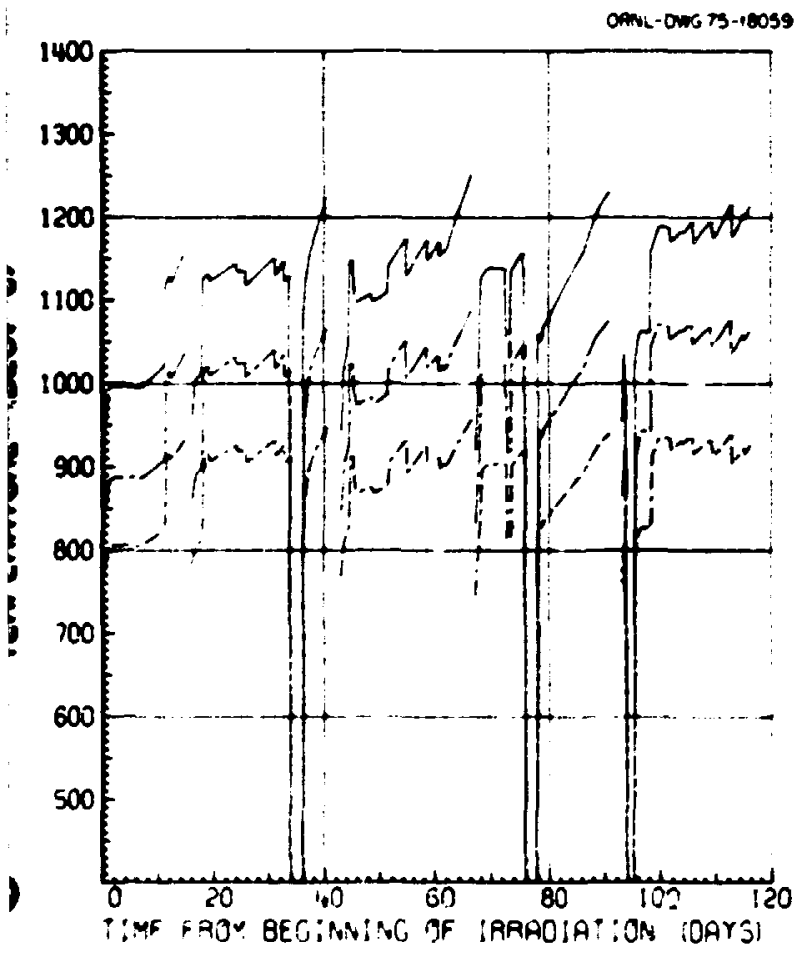


BLANK PAGE

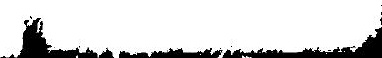




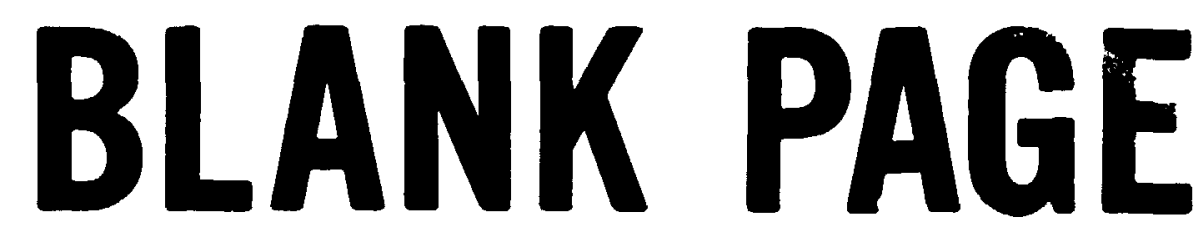




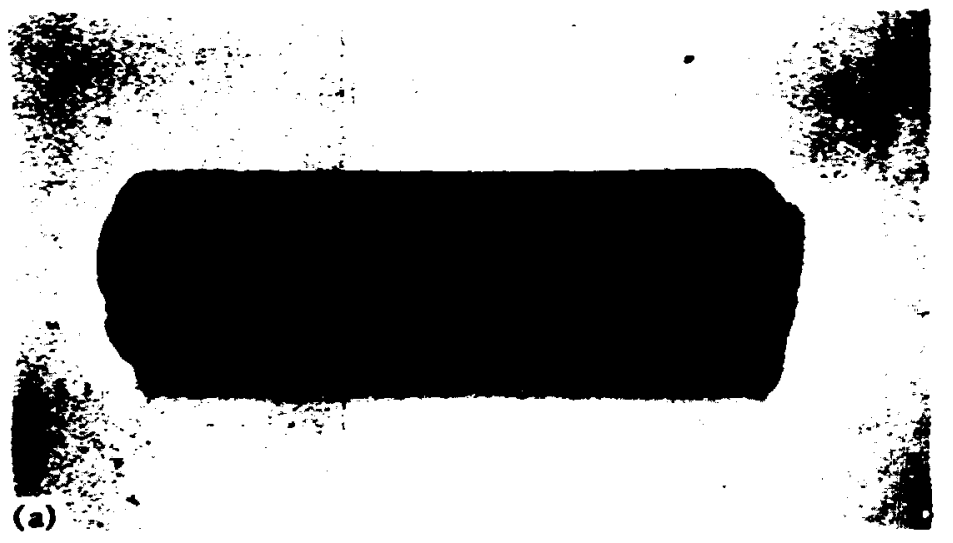

(b)

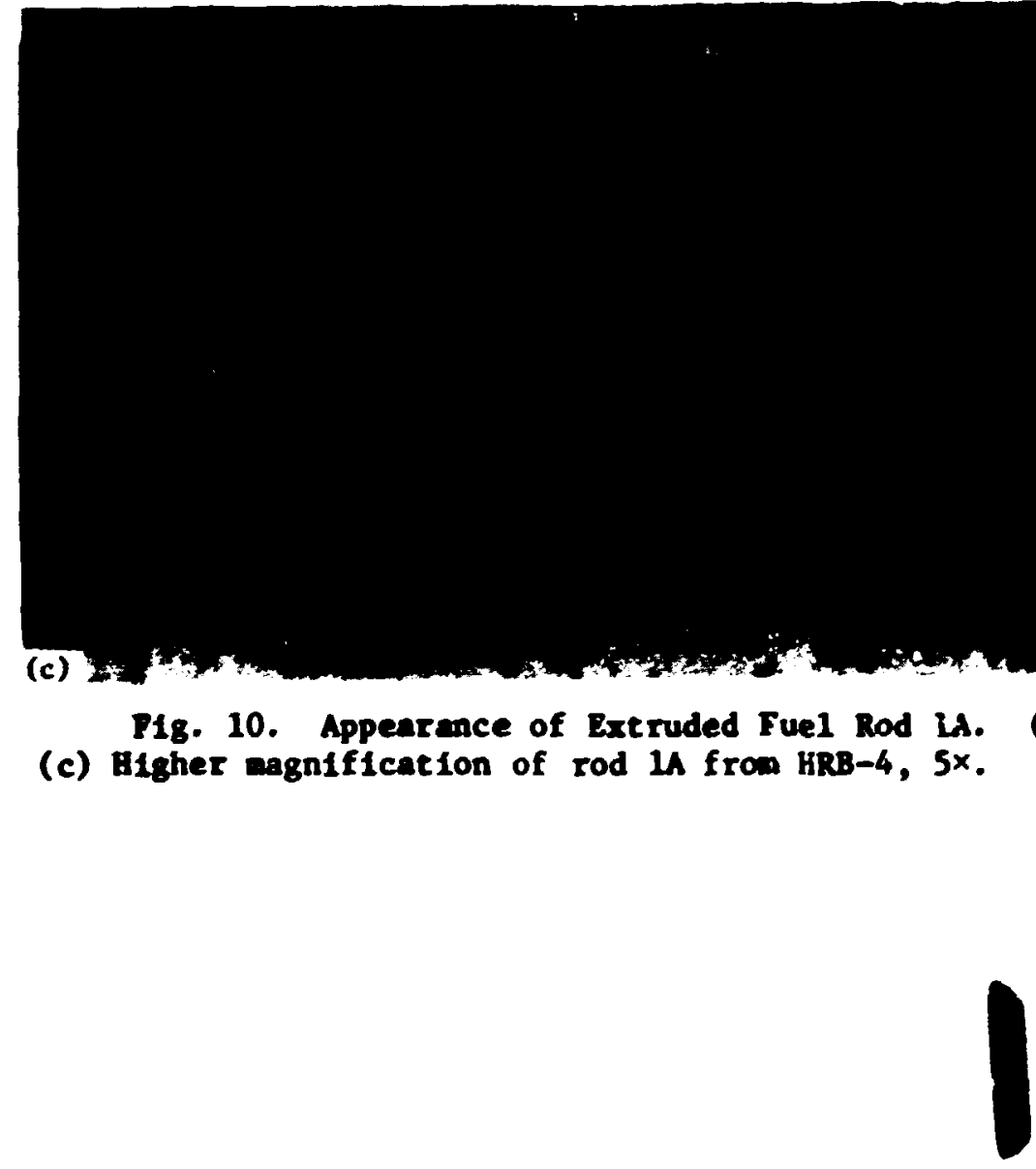




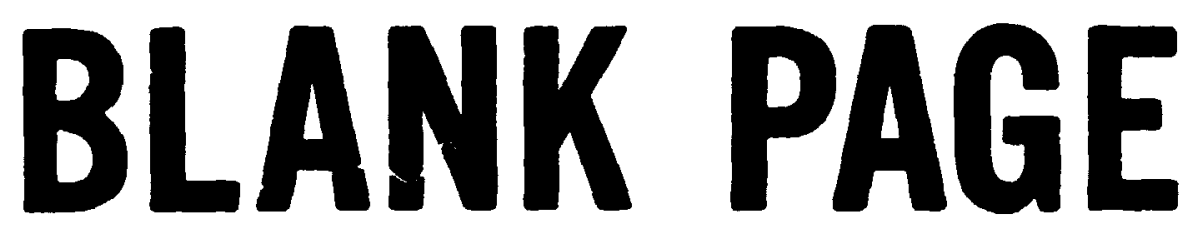




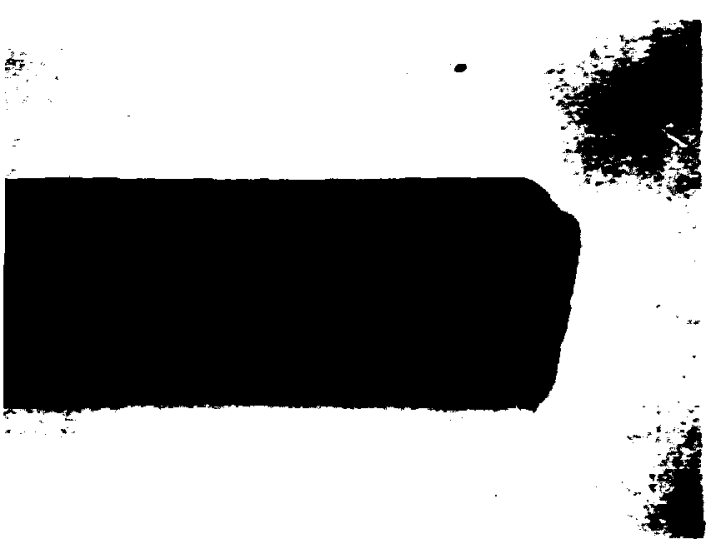

(b)

Appearance of Extrudad Puel Rod 1A. (a) Pr.: HRB-5, 1.8x. (b) Pron BRB-4, 1.8x. gatfication of rod $1 \mathrm{~A}$ fros HRb-4, $5 \times$.
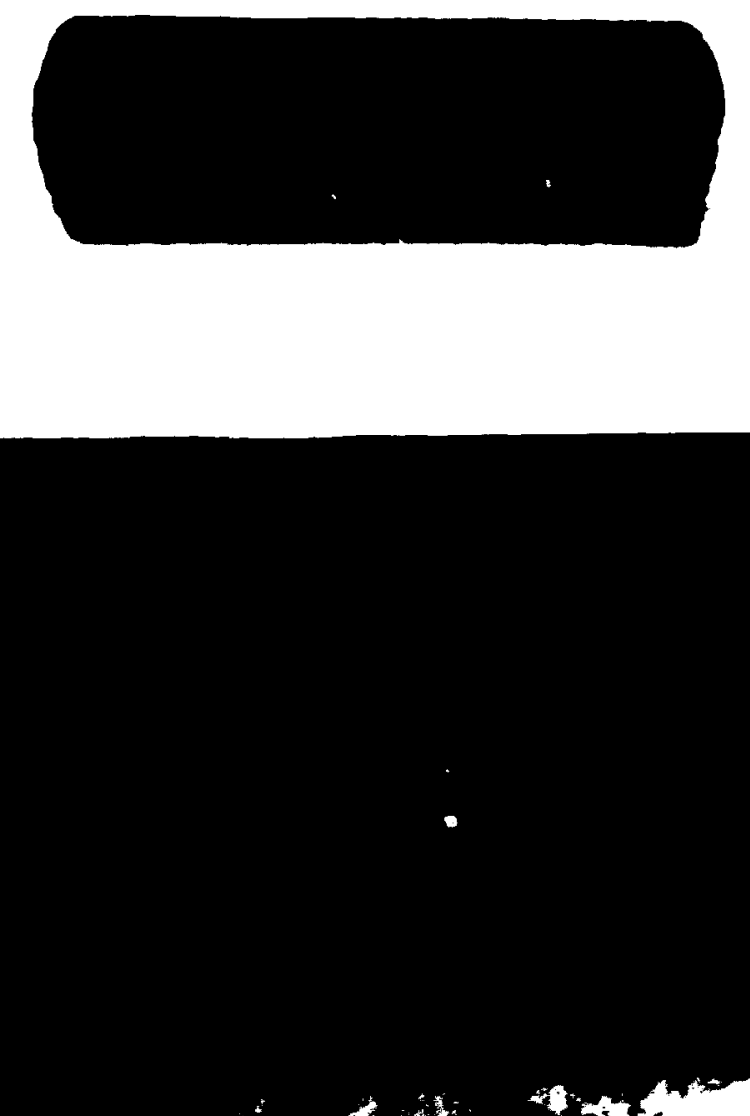

4 is $40+40$

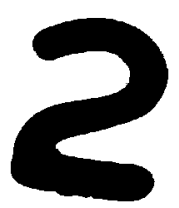




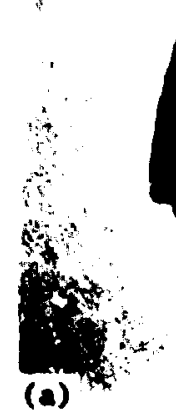

(a)
-

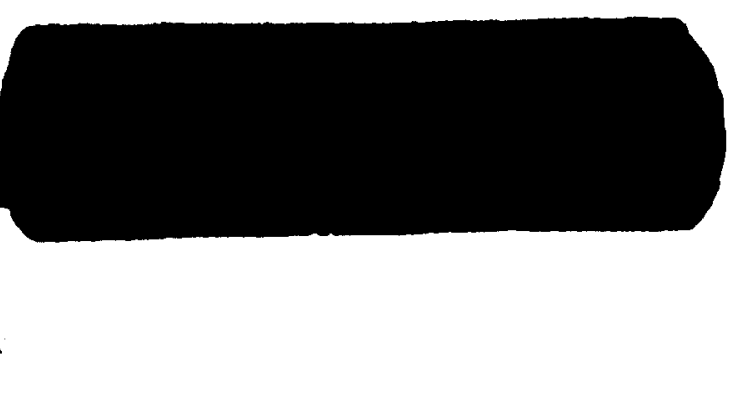

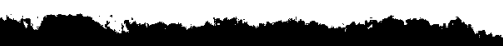

(b)

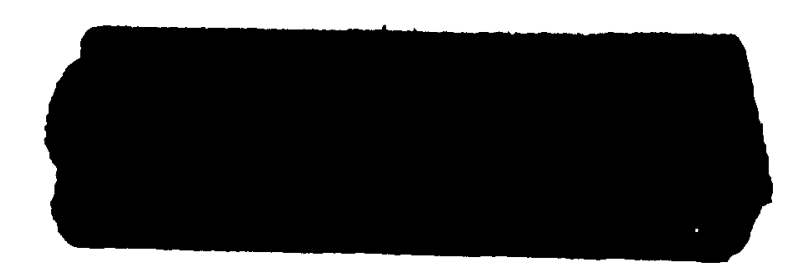

(c)

F18. 11. Appearance of Extruded Rod 18. (a) From HRB-5, 1.8x. (b) From HRB-h, 1.8x. (c) Higher angnification of rod 18 from iRs-4, $5 x$. 


$$
\text { in }
$$




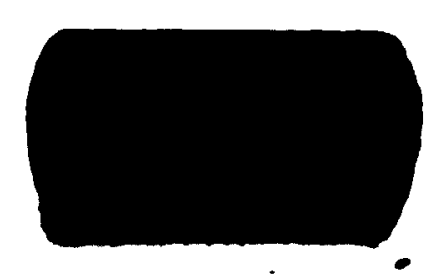

(a)
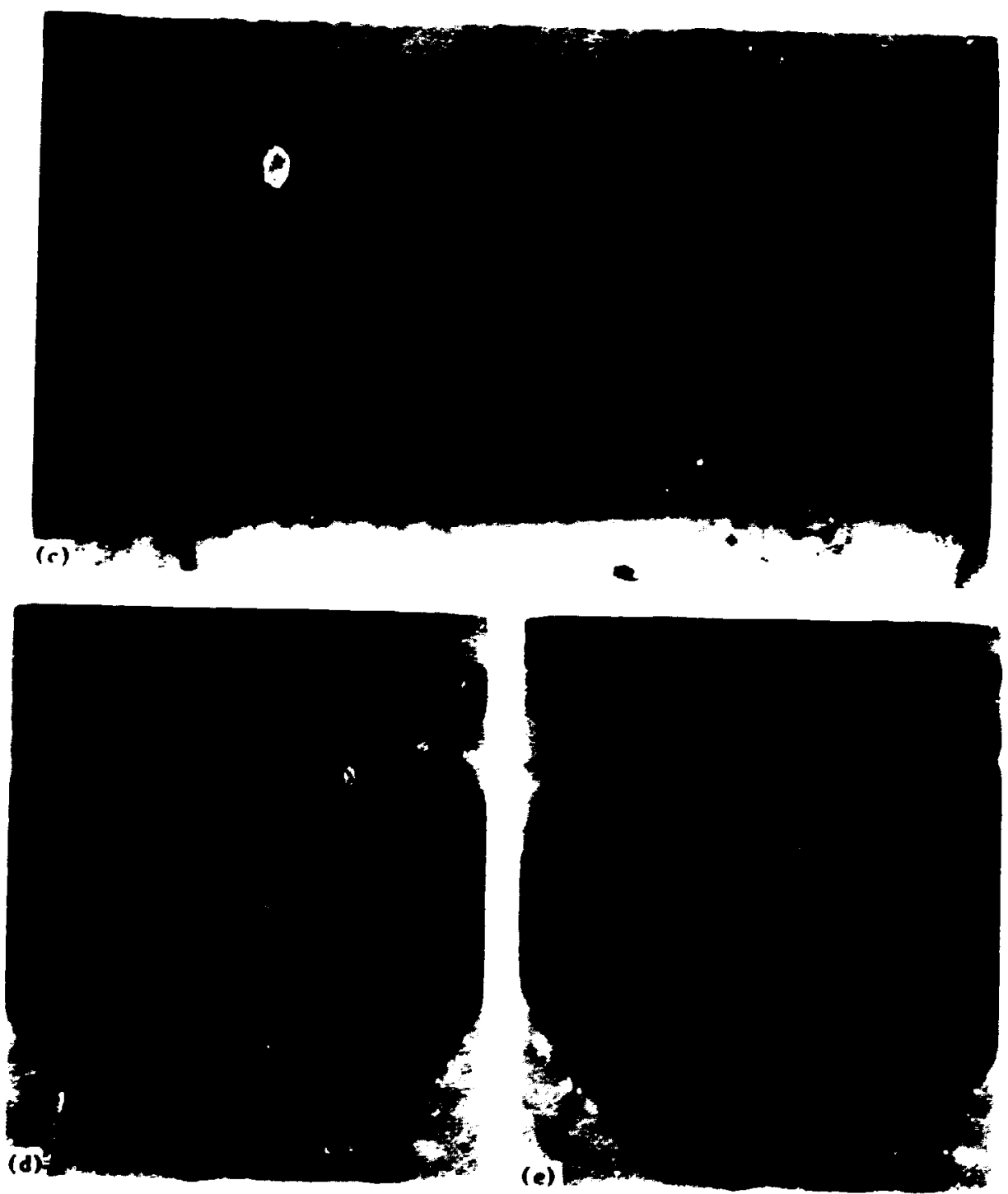

P18. 13. Appearance of Slug-Infected Puel hod $3 C$.

(a) From HRB-5, 1.8x. (b) From HRB-4. 1.8x. Higher angification views of rod $3 C, 5 \%$ (c) side. (d) top, and
(e) bottom. 

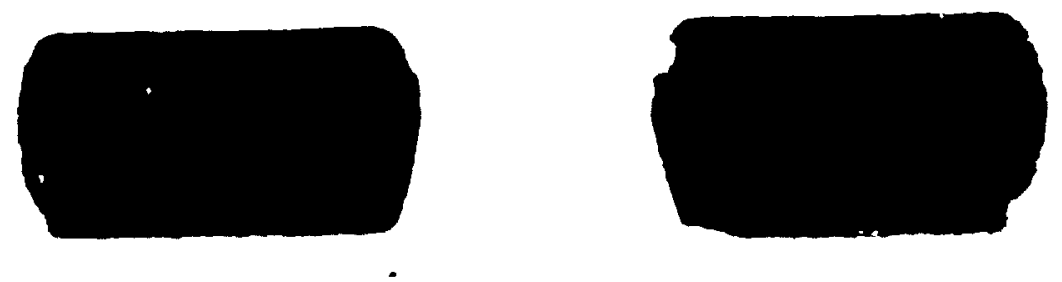

(a)

(b)
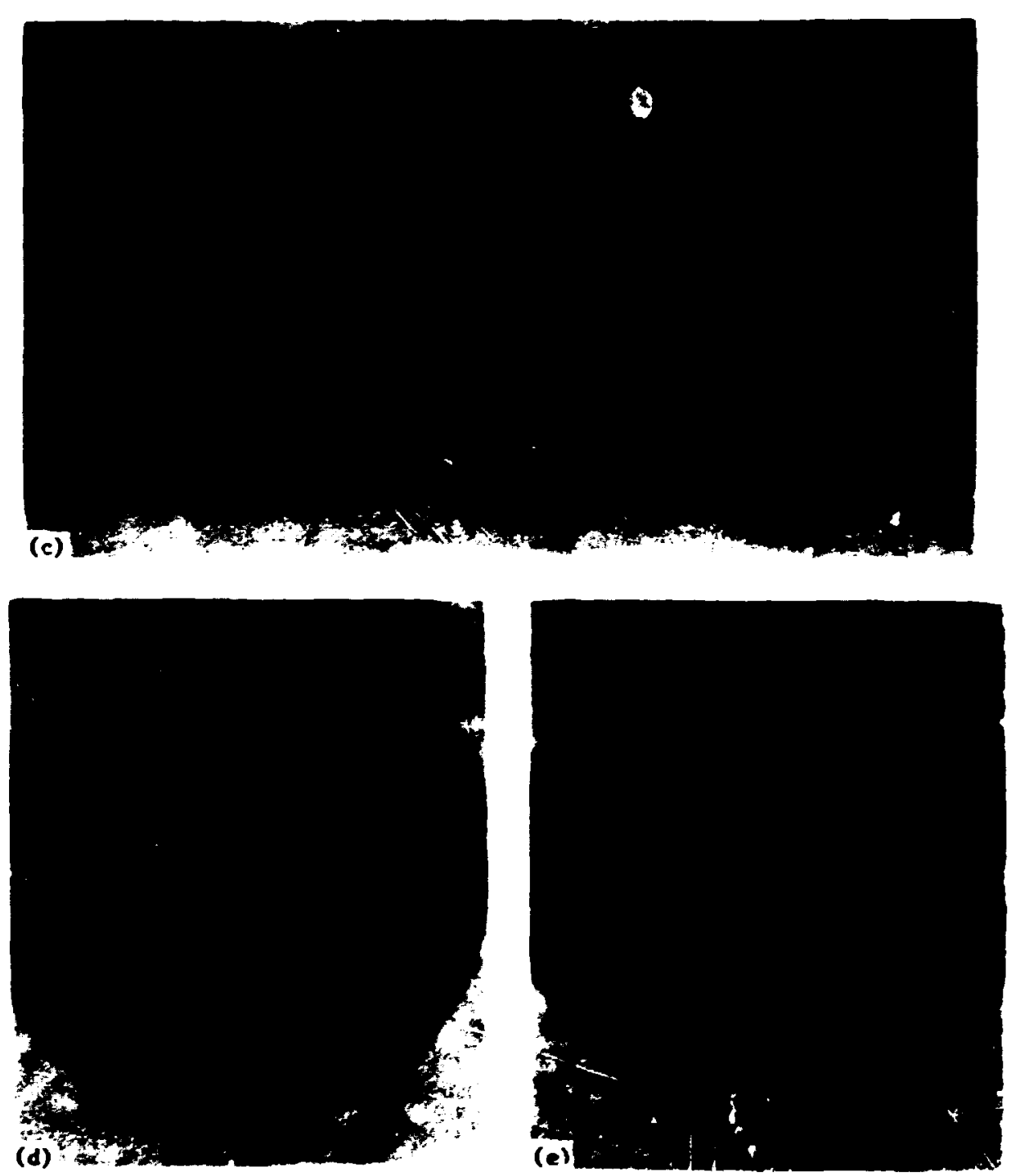

F18. 14. Appearance of Slug-Injected puel Rod 38.

(a) Fron HRB-5, 1.8x. (b) Pron HRB-4, 1.8x. Higher nagniflcation views of rod 3B, 5x; (c) side, (d) top, and (e) bottom. 


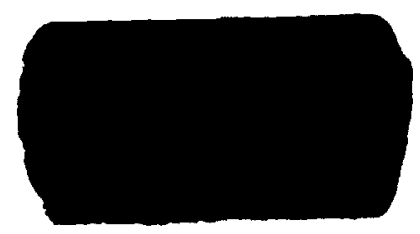

(a)
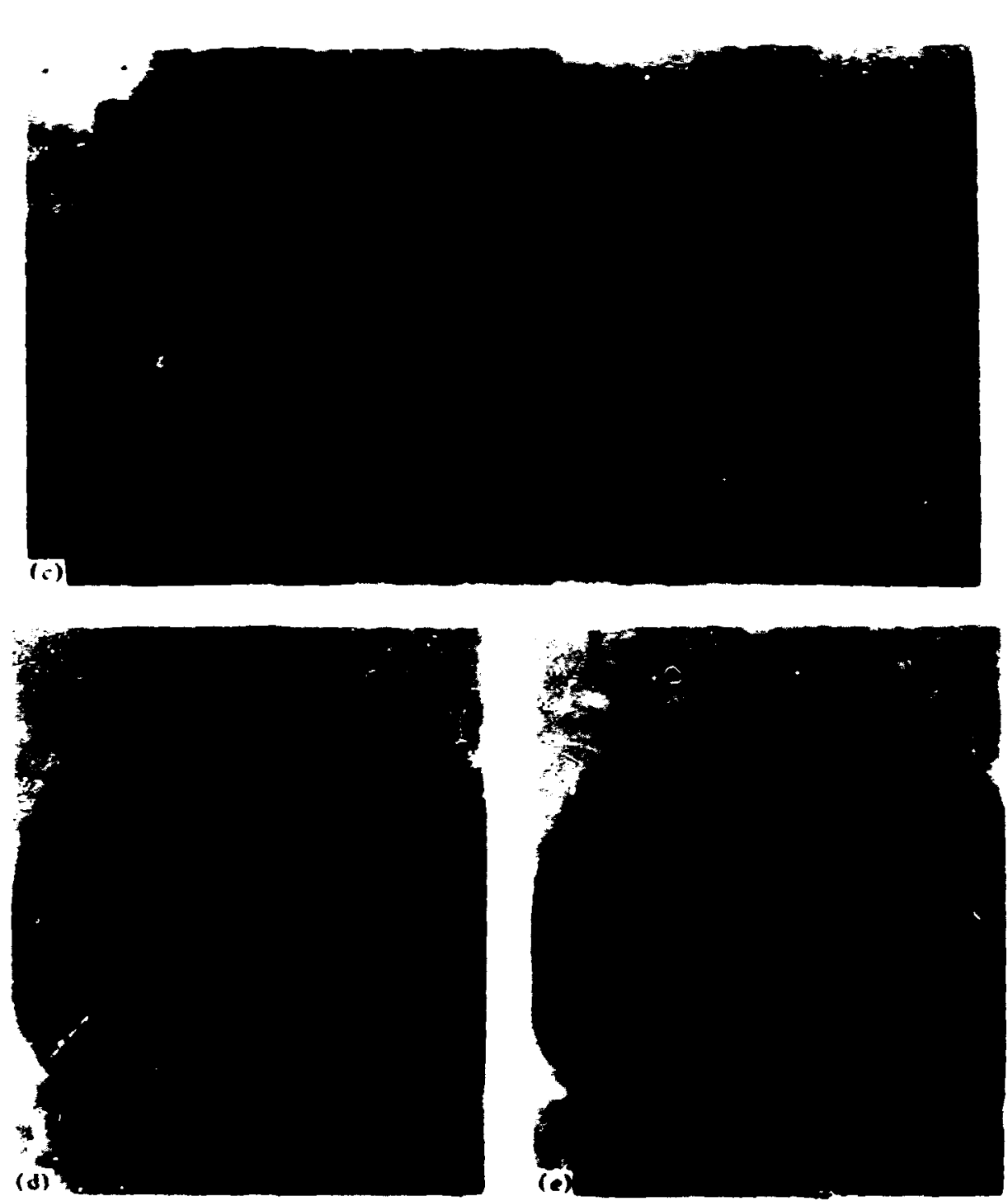

F18. 15. Appearance of Slug-Injected Ruel Rod $3 A$.

(a) From HRB-5, 1.8x. (b) From HiRs-4, 1.8x. Higher magnification views of rod $3 n, 5 x$; (c) side, (d) top, and (e) bottow. 

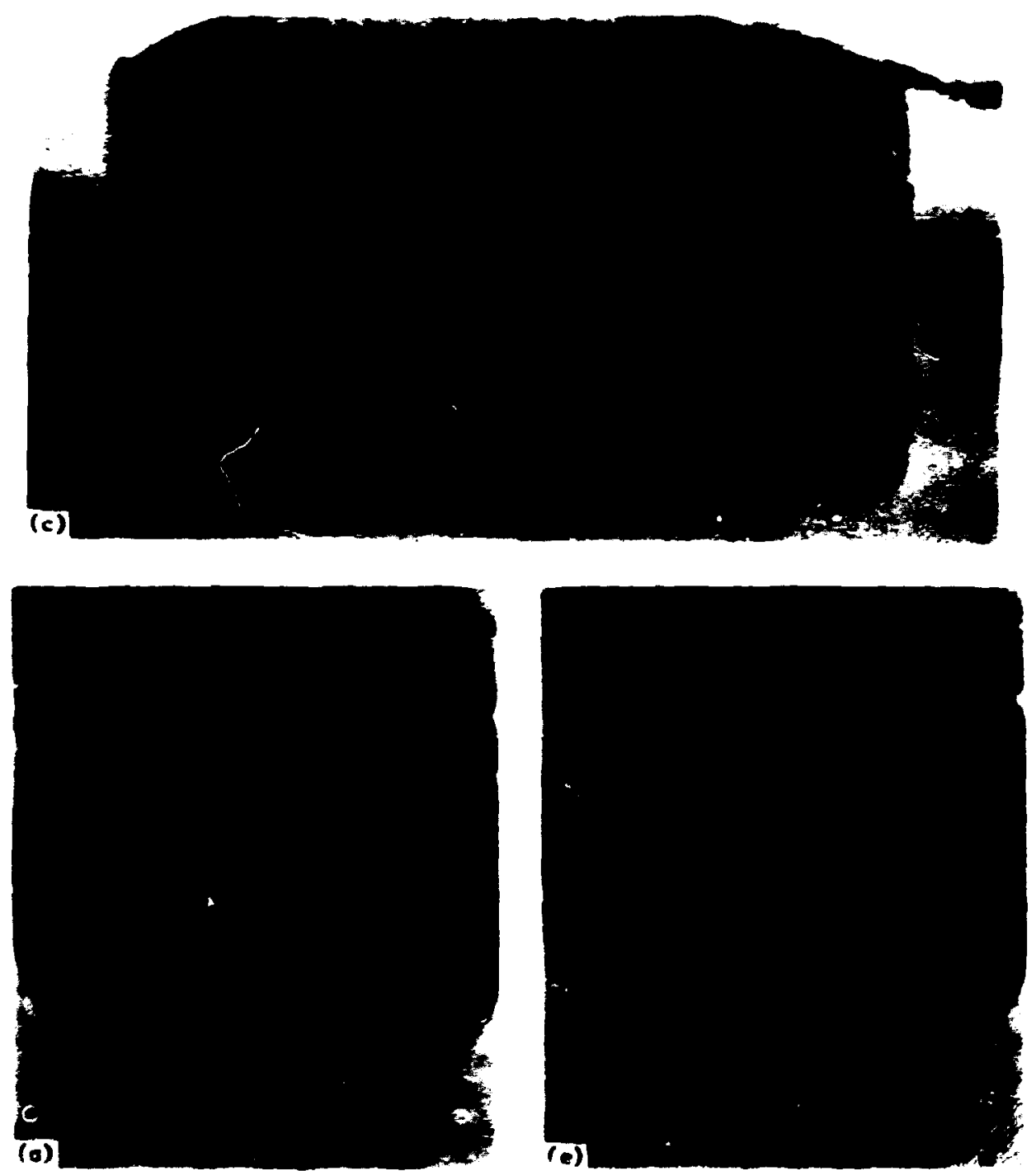

P1s. 16. Appearace of 51us-laje :eed Puel lod 3D.

(a) From His-5, 1.8x, (b) Iro mb-4, 1.8x, H1gher asgn1flcacior views of rod 3D, 5x; (c) ilde, (d) rop, and (e) ber:ess. 


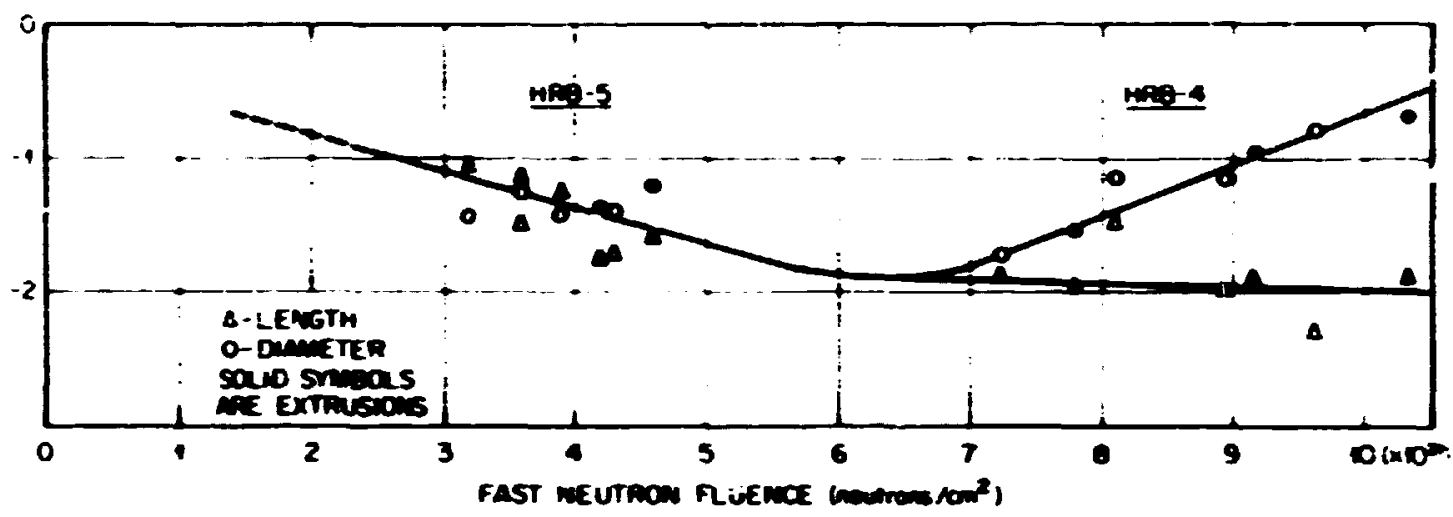

Fig. 17. Dimensional Changes of Fuel Rods from HRB-4 and -5 Exper iments.

The matrix densities were about $1.7 \mathrm{~g} / \mathrm{cm}^{3}$ for the extruded rods and ranged from about 0.6 to $0.8 \mathrm{~g}, \mathrm{~cm}^{3}$ for the slug-inje:ted rods. The onset of anistropic shrinkage expected in the extruded rods ras observed at about $6.5 * 10^{2}$ neutrons $/ \mathrm{ca}^{a}$. The surprising result was that the close-packed (slug-injected) rods showed the same anistropic behavior. A check of the dimensions ce the slug-injected green rods vs carburized vs annealed rods did not show any trend toward anistropic shrinkage. One way $m$ explain this ef fect vould be to assume that the matrices of not only the ex:ruded rods, but the slug-injected rods as well, have a preferred o-ientation; and at fluences above $6.5 \times 10^{21}$ neutrons $/ \mathrm{cm}^{2}$, Biso coatings have densified suffictenty so that the atrix becones the cratrolling factor. resuiting in anistropic shrinkage of the slug-injeet,d fuel rods. The continuous matrix of an extruded rod is always tise controlling shrinkage factor, since the volune of the rod occupied by coated particles is cnly about $30 z$.

\section{Metal lographic Exmination}

Metal lographic sections of the four slug-injected rods were examined to determine the effect of carbonizaticn wode on the irradiat ion performance of the three atrix compsitions. The appearance of radial sections through the slug-injer.ted rods from HRB-5 is shown in Figs. 18-21; no gross differences bet reen the rods were apparent in these low-magnification views. Exanination of the matrices at higher magnification revealed significan: microstructural differences, as shown in Figs. 22-25. These differences reflected the matrix composition, carbonization mode, and denelfication from fast-neutron iamage. The relat lonship between matrix type and microporosity is 


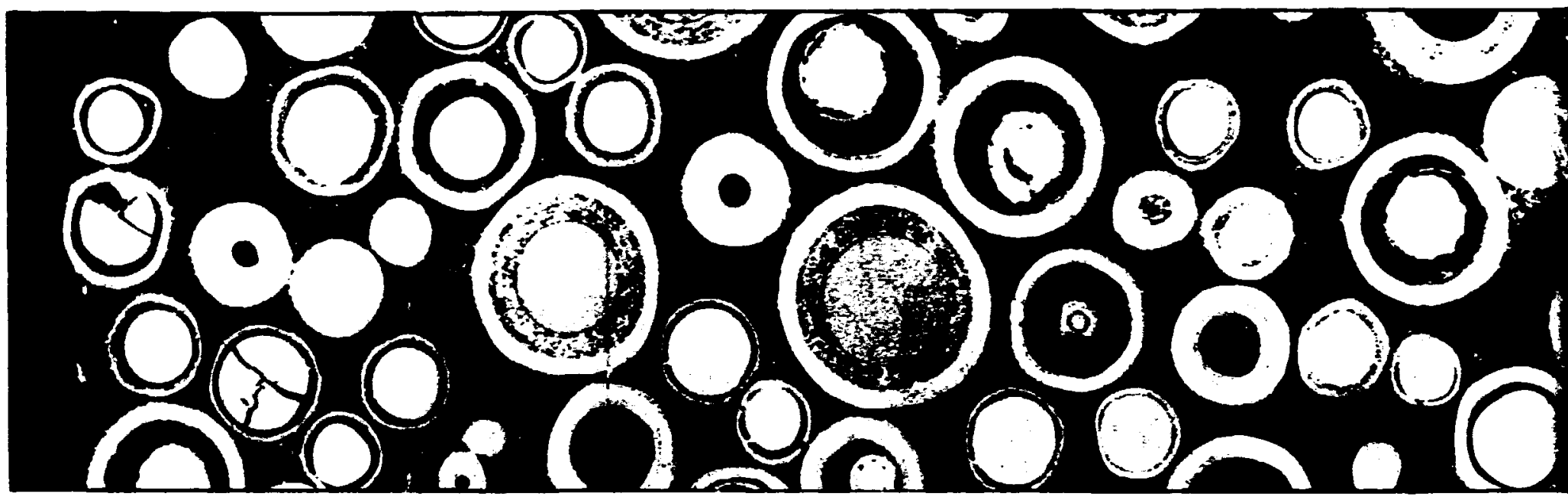

Fig. 18. Radial Section Through Slug-Injected Fuei Rod 3A Irradiated in HRB-5. This fuc was bonded with FSV reference matrix and carbonized in packed alumina.

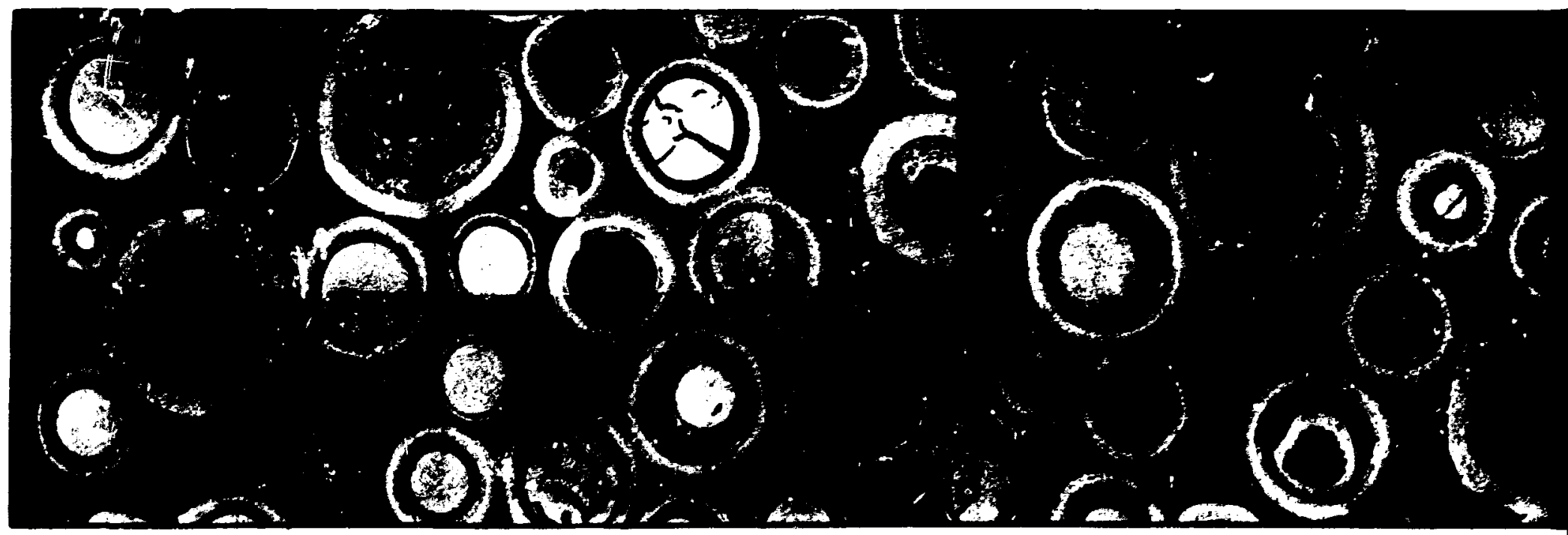

Fig. 19. Radial Sertion Through Slug-Injected Fuel Rod 3B Irradiated in HRB-5. This fue was bonded with $40 \% \mathrm{RC}: 4$ in 2240 pitch and carbonizcd packed alumina. 


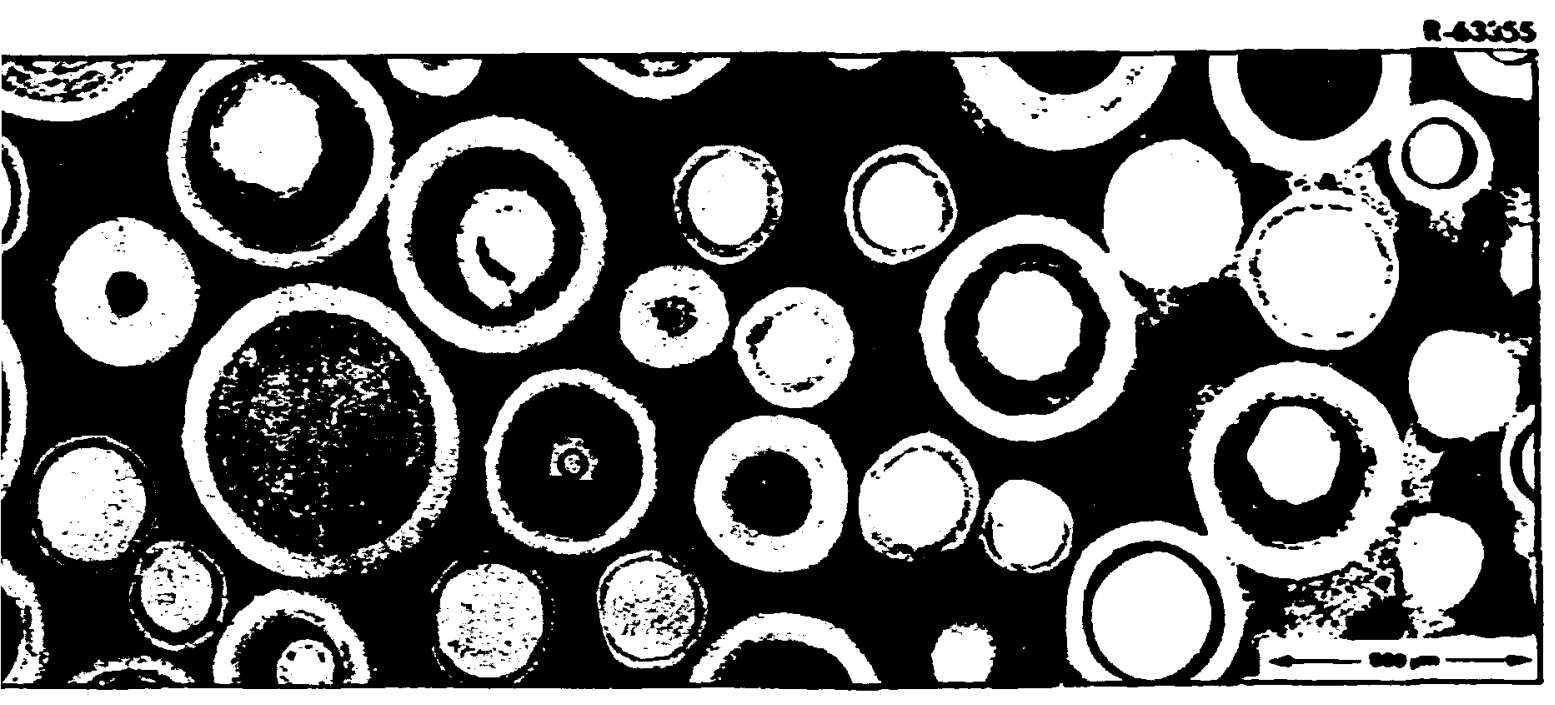

rough Slus-Injected Fuel Rod 3A Irradiated In HRB-5. This fuk: rod trix and carbunized in packed alumina.

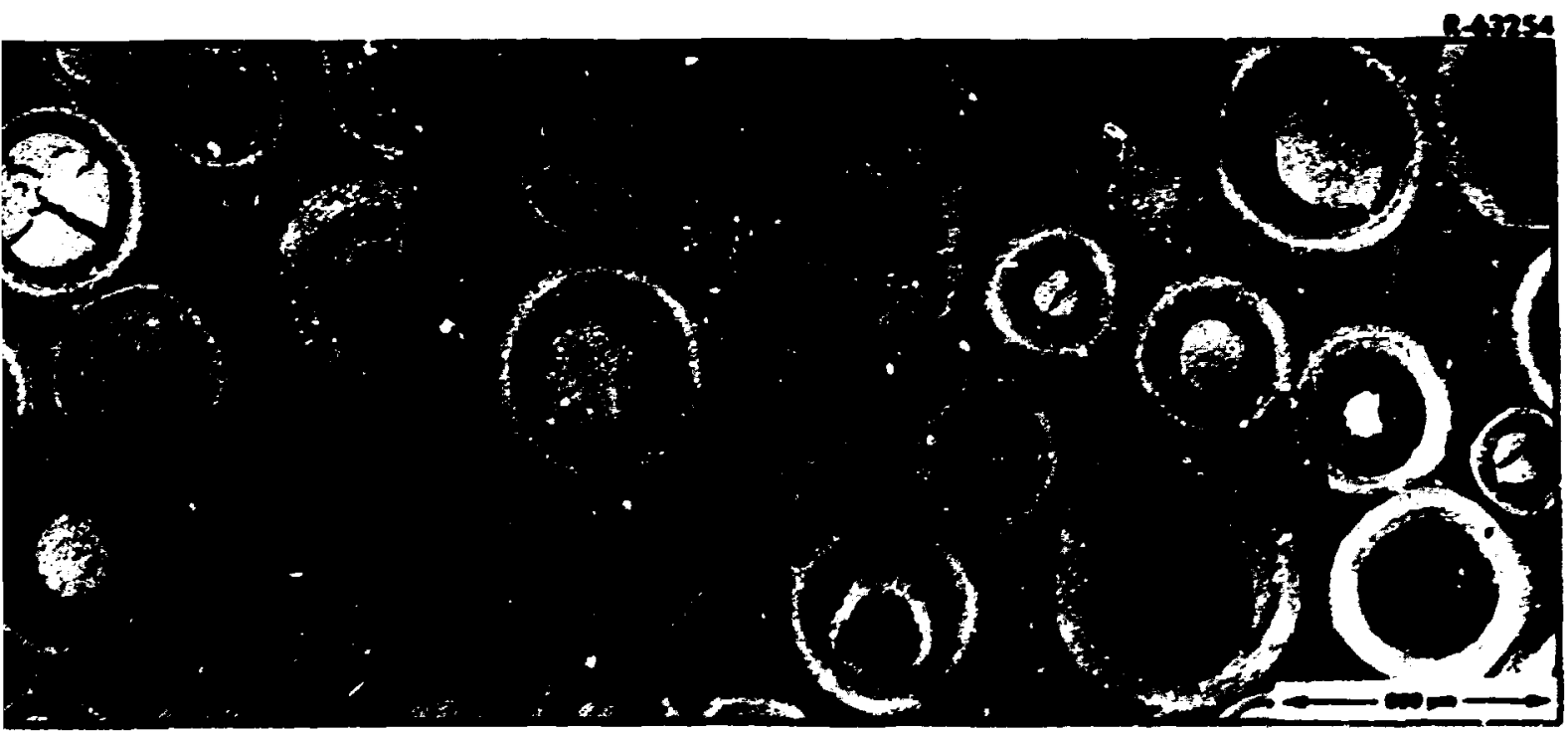

rough Slug-Injected Fuel Rod 3B Irradiaced in HRB-5. This fuel pitch and carbonized packed alumina.

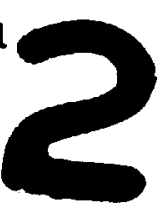




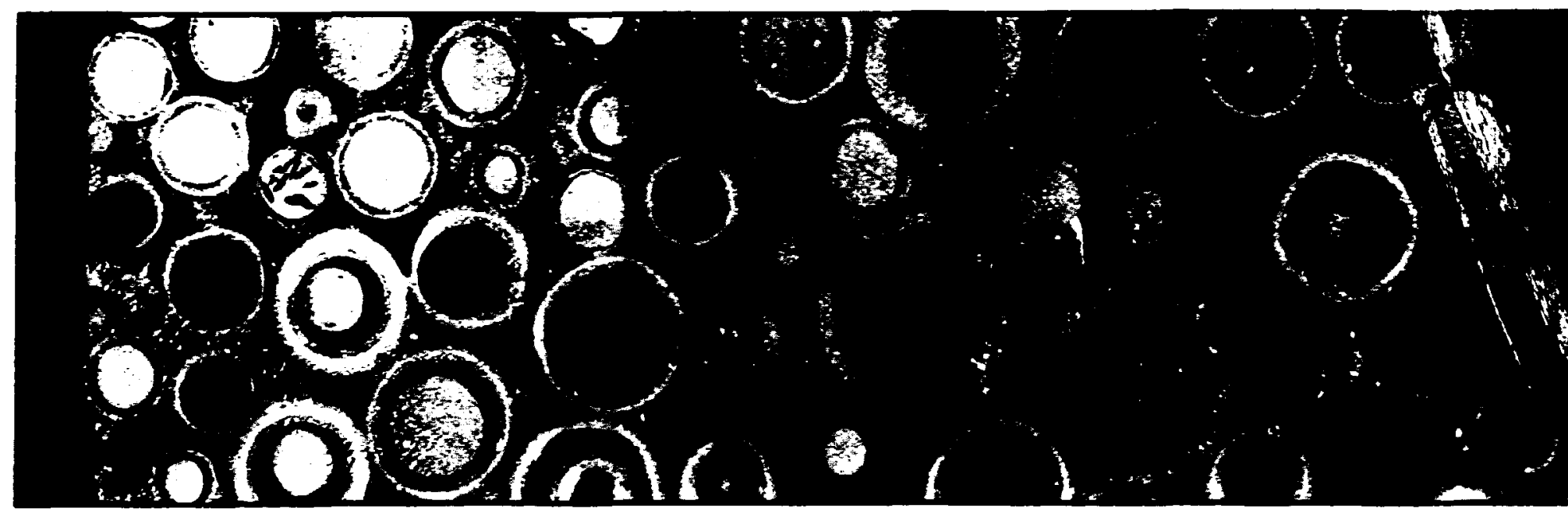

Fi8. 20. Radial Section Through Slug-Injected Rod $3 C$ Irradiated in HRE-5, Bonded $y$ in 1240 Pitch and Carbonized in H-327 Graphite Block.

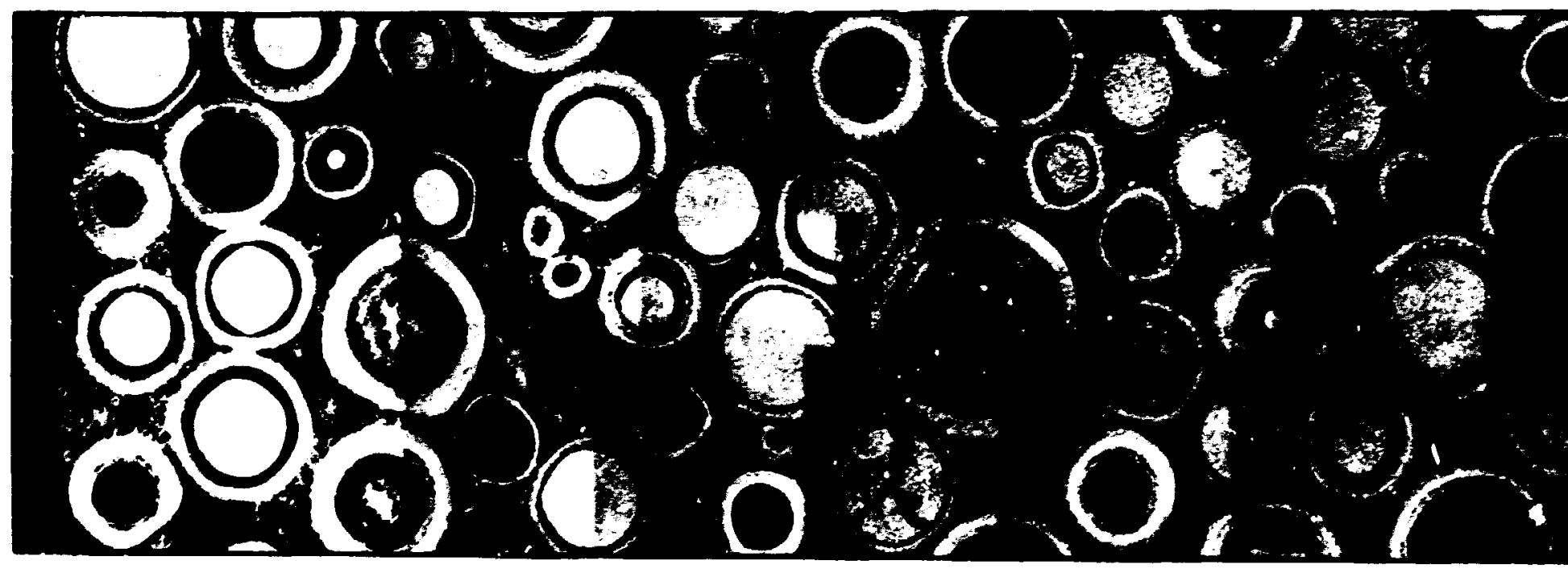

Fig. 21. Radial Section Through Slug-Injected Fuel Rod 30 Irradiated in HRB-5, Bonc 402 GCL 1089 in A240 Pitch and Carbonized in H-327 Graphite Block. 


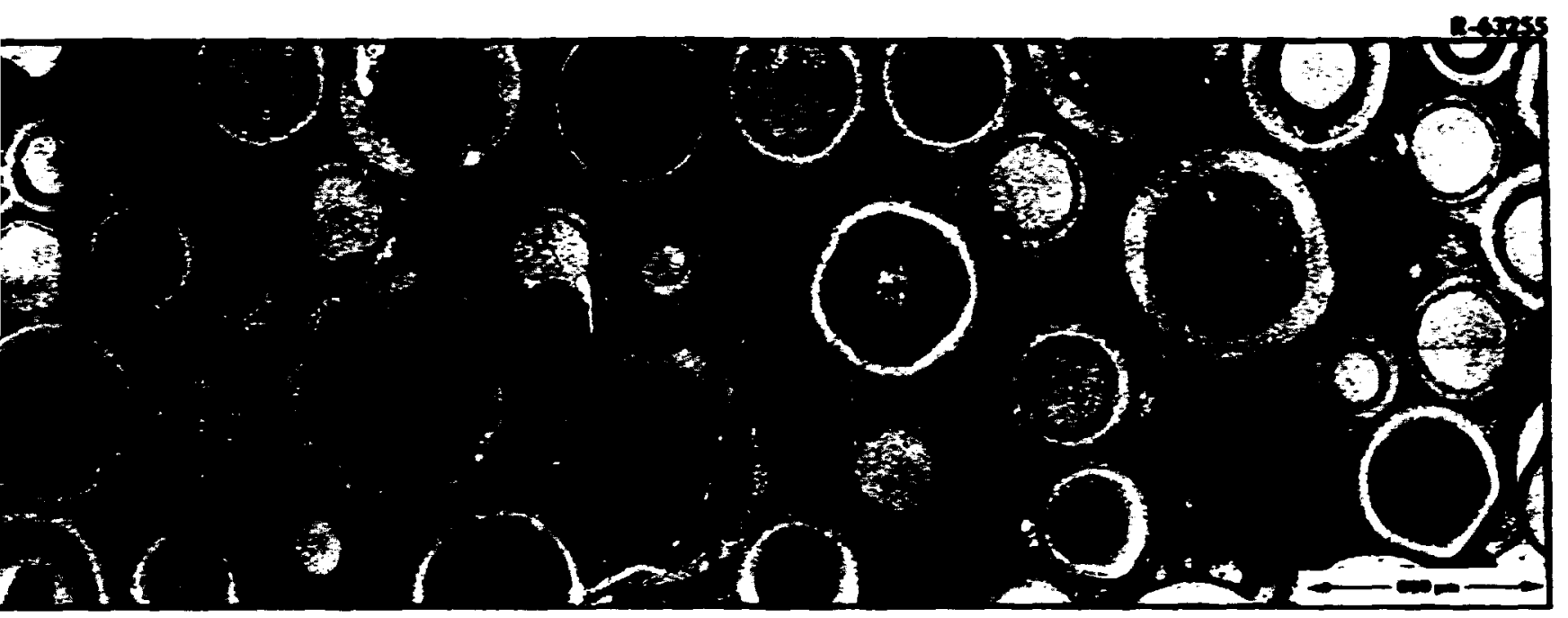

ection Through Slug-Injected Rod 3C Irradiated in HRB-5, Bonded with 402 RC4 atzed in A-327 Graphite Block.

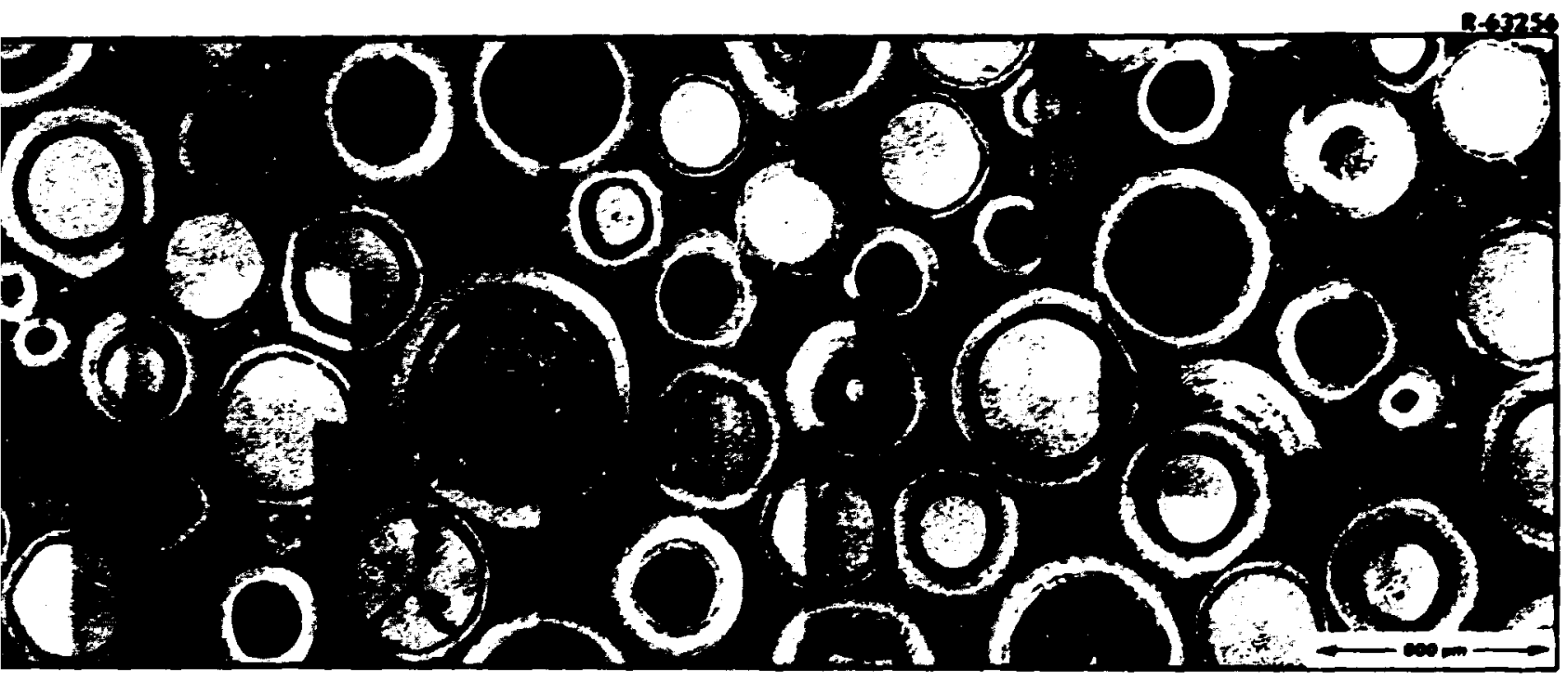

ection Through Slug-Injected Fuel Rod 3D Irradiated in HRB-5, Bonded with ;ch and Carbonized in H-327 Graphite Block.

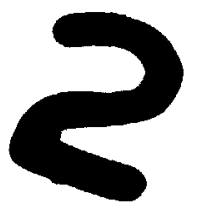




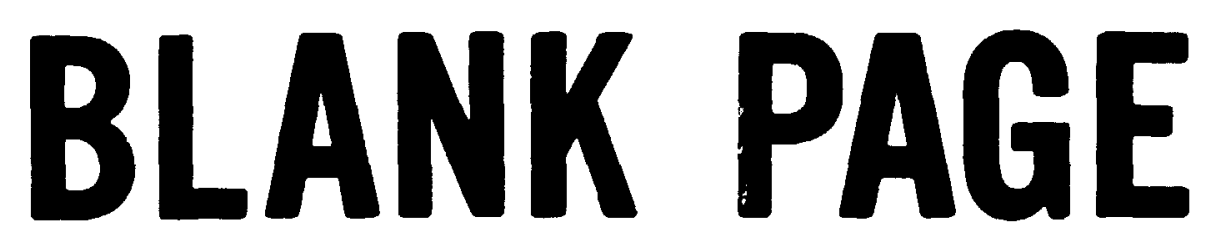



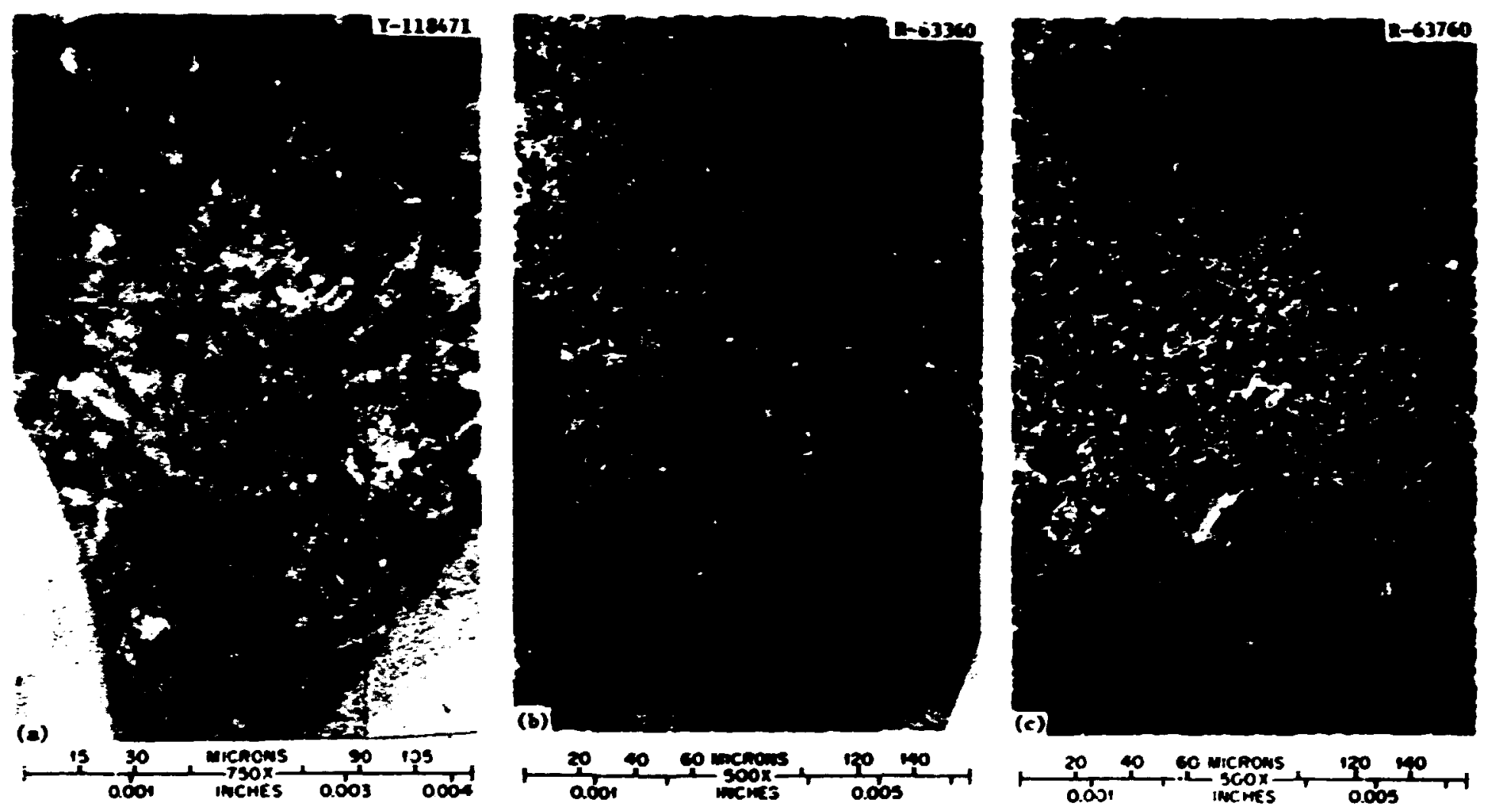

F18. 22. Appearance of Matrix in Puel lod 34 That Resulted Fron 29.6 we 7 Asbury 6353 and Ashland 1240 Pitcl, Carbonized in Packed $\mathrm{Al}_{2} \mathrm{O}_{3}$ (PSV Reference Matrix). (a) As-fabricated. (b) After $4.2 \times 10^{21} \mathrm{nicm}^{2}$. (c) After $9.6 \times 10^{21} \mathrm{n} / \mathrm{cm}^{2}(E>0.18 \mathrm{MeV})$. 


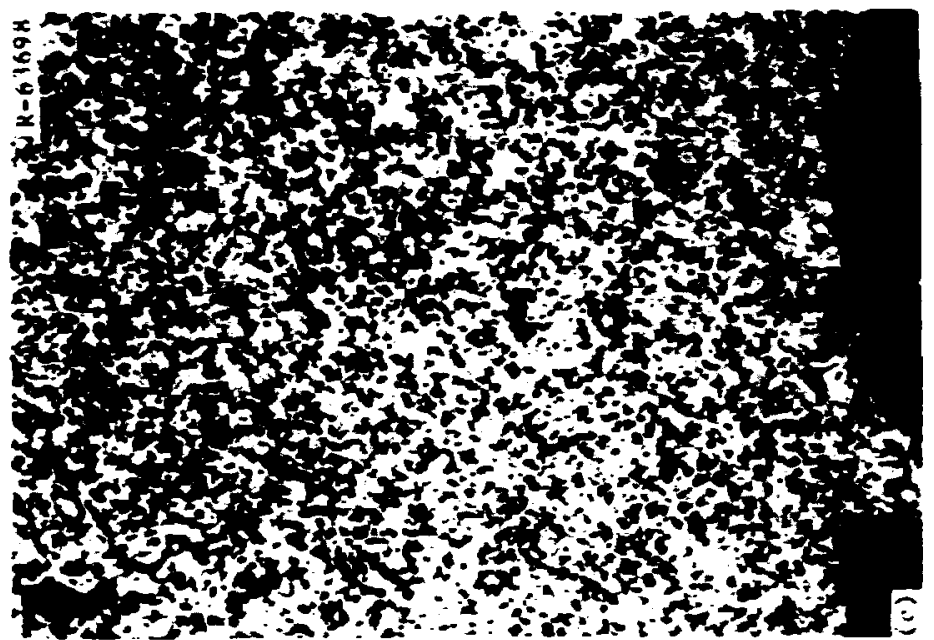

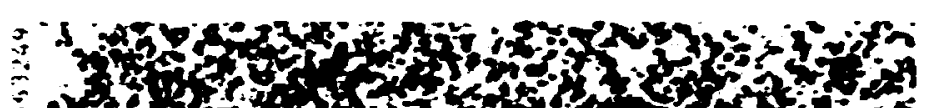
i. s.

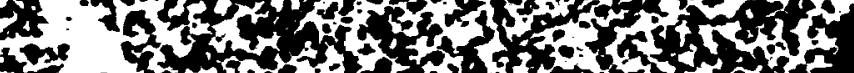

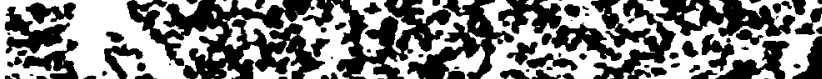

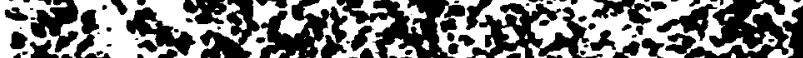

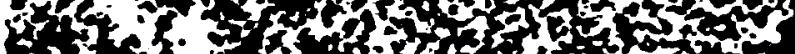

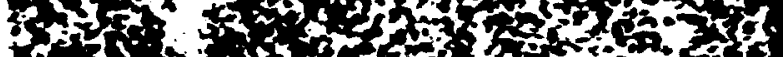

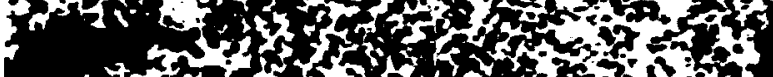

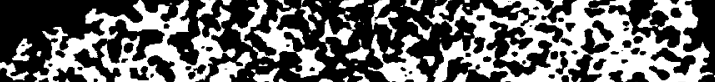

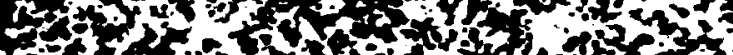

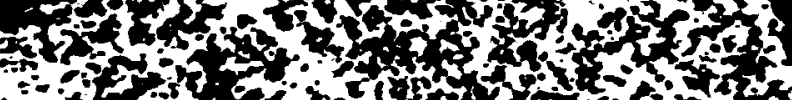

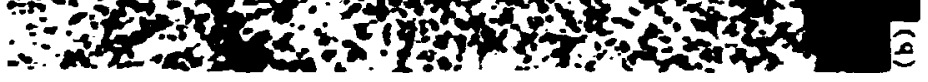

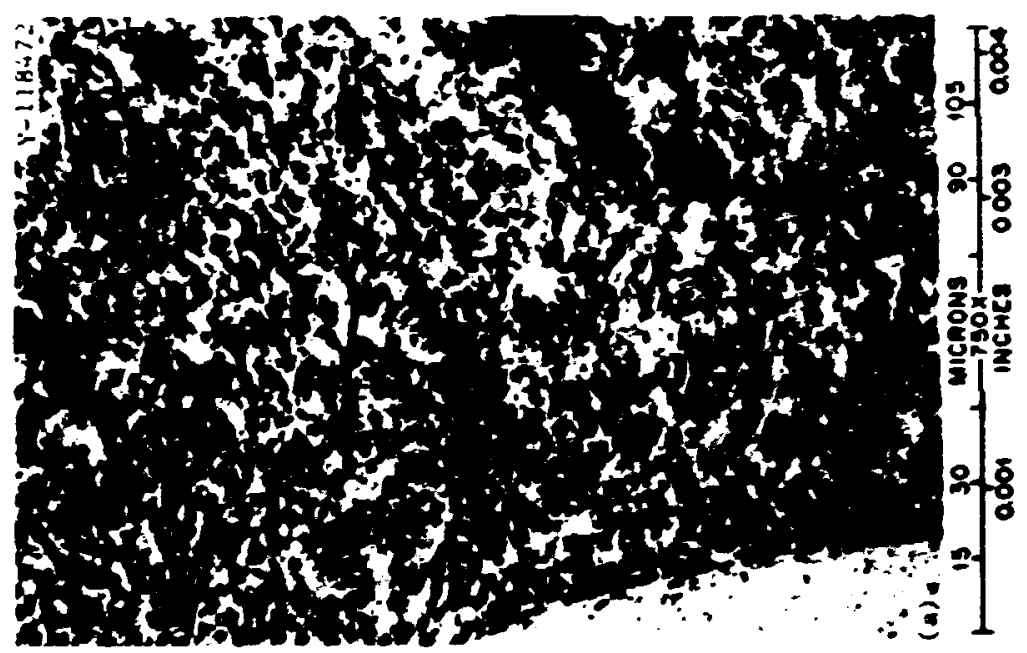

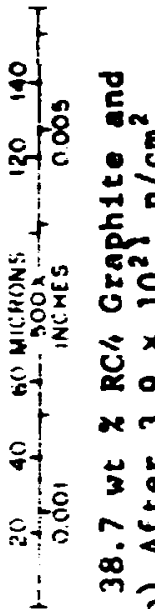
$1 \quad \mathrm{E}$ E if T: 율

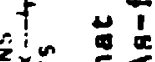
古< 的品 of م

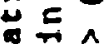
20 60 N บㄷํㅇ른 둘 思 \% 운응 $\underset{*}{*} \times$ a 象 $\therefore<$ 告点 起 

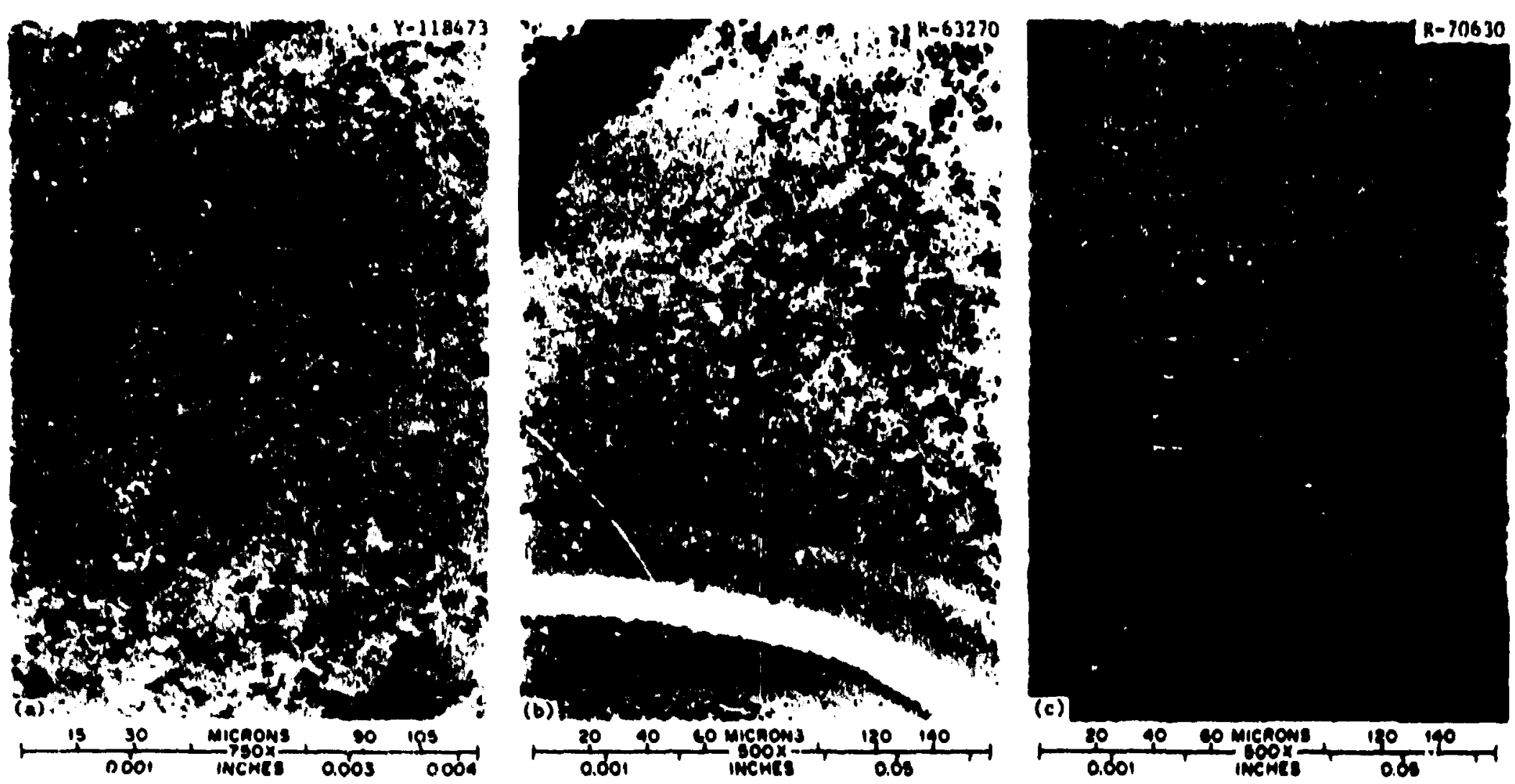

F18. 24. Appearance of Matrix in Fuel Rod 3C That Reaulted from 38.7 wt $X$ RC4 Graphite and Ahland 1240 Pitch Carbonized in it-327 Graphit. Block. (a) As-fabrlcated. (b) After $3.6 \times 10^{21} \mathrm{n} / \mathrm{ca}^{2}$. (c) After $8.1 \times 10^{21} \mathrm{n} / \mathrm{cm}^{2}(E>0.18 \mathrm{MoV})$. 

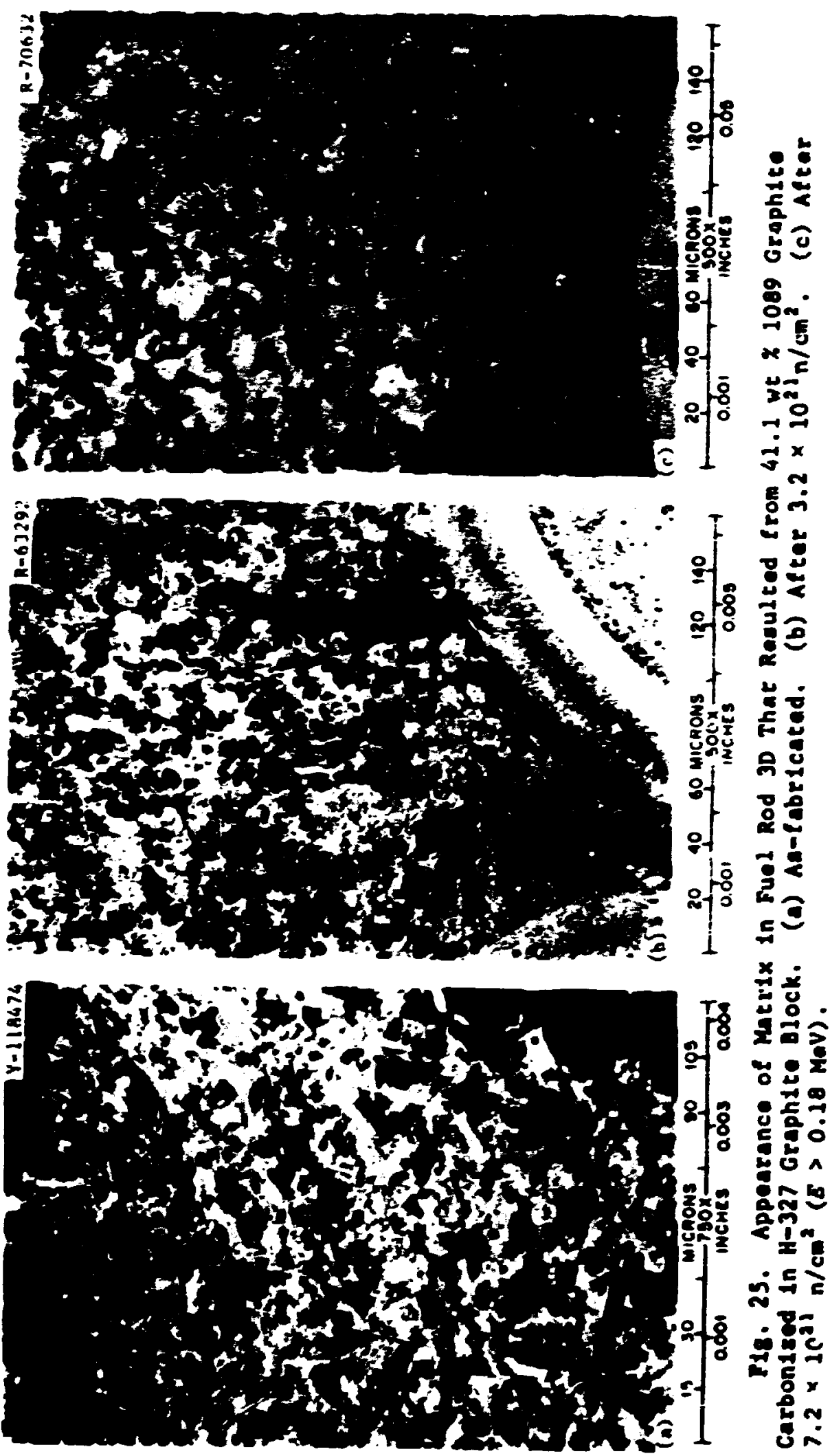
given in Table 11 for the as-fabricited controls and the frradiated rods. is can be seen in this table, there was considerable variation in nicroporosity between the as-fabricated ruds, with a low of 212 occurring in rod $3 C$, which also had the highest atrix density and pitchcoke yield. The individual graphite filler particles vere discernable in the as-fabricated rods that contained the Fort St. Vrain (FSV)-type (3A) and experinental antrices that vere carbonized In packed $\mathrm{Al}_{2} \mathrm{O}_{3}$. The matrices of the rods carbonized in graphite tubes vere nore dense, and the individual filler particles were not discernable. The denser eatrices resulted from the higher yield of coke from the pitch in rods carboaized in the graphite tubes. With the exception of rod 30 , additional densification (decrease in aicroporosicy) of the atrices occurred during irradiation.

Table 11. Variacion in Microporosity of Matrices Used in Fabricating Fuel lods for Hiss-4 and -5 with Matrix Density, Pitch-Coke Yield, and Fast-lleutron Damage

\begin{tabular}{|c|c|c|c|c|}
\hline $\begin{array}{l}\text { Fuel Rod } \\
\text { Identification }\end{array}$ & $\begin{array}{l}\text { Micro- } \\
\text { porosity } \\
\text { (z) }\end{array}$ & $\begin{array}{c}\text { Fast } \\
\text { Fluence } \\
(E>0.18 \text { MeV })\end{array}$ & $\begin{array}{l}\text { Matrix } \\
\text { Density } \\
\left(8 / \mathrm{cos}^{3}\right)\end{array}$ & $\begin{array}{l}\text { Pitch-Coke } \\
\text { Yield } \\
\text { (I) }\end{array}$ \\
\hline 3A, as fabricated & 63 & & 0.56 & -20 \\
\hline 3 , ERB-5 & $4^{\circ}$ & $4.2 \times 10^{-21}$ & & \\
\hline $3 A$, BRE-4 & 23 & 9.6 & & \\
\hline 38, as fabricated & 27 & & 0.73 & -25 \\
\hline 38, HRB-5 & 28 & 3.9 & & \\
\hline 38, BRs-4 & 25 & 8.9 & & \\
\hline $3 c$, as fabricated & 21 & & 0.83 & -40 \\
\hline $3 c$, BDe-5 & 16 & 3.6 & & \\
\hline 3C. $\mathrm{HRB}-4$ & 9 & 8.1 & & \\
\hline 30, as fabricated & 25 & & 0.84 & -38 \\
\hline 30 , HRB-5 & 30 & 3.2 & & \\
\hline 3D, $\operatorname{ARE}-4$ & 25 & 7.2 & & \\
\hline
\end{tabular}

ace Table 4 for atrix composition and cartonization node. 
Close exmination of the fuel rods revealed no falled particles In the rods fabricated with the FSV atrix ( 3 ; , except for an occasloas inert Biso particle that had been crushed during fabrication. Nor vere any falled fuel particles observed in the fuel rods with an experineat al atrix carboaized in packed $\mathrm{Al}_{2} \mathrm{O}_{3}$ (31). However, * sfentétcant auber of pyrolytic carton contings in the rods with experinental antrices carboatzed in graphite cubes ( $3 \mathrm{C}$ and 30 ) had falled as a result of antrix-particle inceraction. To typical areas froe rods $3 C$ and 30 Irrediated in Bx-4 are shown In Fis. 26; as can be sem, the fallure frequency of the pyrocarbon contings us greatest in 3c. Higherangification views of falled Biso and Iriso contings ca inert hernels are showa in Fig. 27. Although no falled Biso-couted Mno particles were observed, cears in the LTI coating were present that extended abnut halfway through the soating thickness (FIs. 28). Exsaination of the as-fabricated rods in carbonized graphice ( $3 C$ and 30 ) revealed that anall tears were present in the outer contites of the Biso- and Trisocoated particles (Fis. 29). These cears forned durins fuel red fabrication and were the initiation sites of conting fallure as the wetix and coatings denotf led uith fast fluence.

The appearance of a radial section throwh an extruded rod, 1C, fron His-4 is shown in F18. 30; except for a slight exageration of the cracks, no obvious changes were apparent in the coat incous merix. Examination of the conted particles at a higher acenification revealed that a significant nuber (-25Z) of the SiC costings on the Trisocoated fissile kernels contained cracks [F18. 31(a)], wone of the SiC layers on the Triso-coated inert kerwels exhibited cracks. (The thickness of the SiC layer was about 15 in on the lecrt particles and 32 wo on the fisalle particles.) Close exmination of the archive saple revealed that fise cracks were present in the SIC layers on the fissile particles of the as-extruded rods and were exasseratad by irradiation. Mose of the LII outer lajers on the fissile particles had failed, although a few $(-27)$ of the inaer LII coacings had falled in particles that contained cracked SiC layers [Fig. 31(b)]. With the exception of one craciced irart Biso particle, sone of the Biso-coated particles showed evidence of pocential fallute, ajr was there any evidence of atrix-particle inceraction.

Thus, it appears that in-block carbonization has presented sone unexpected problem. Also, there are appareat problen with the extruded fuel rods, since an unacceptable fraction of cracked SiC layers were present in the Triso fissile particles in the as-fabricated condition. Irradiation teating either ixcreased the nuber of cracked SiC layers or rirely enhanced then, so that they were auch woze readily decected during motallosraohic exainstion.

Metallographic exalnation of the Triso-ccated war fissile particles zontained in the slus-infected rode revealed several potential problems for the SiC layers. In the relativeis ansll nuber of fissile particles exposed in the planes of Dolish, about oas-third stromed evidence of attack in isaner surface reefions of the SIC layers. This attack appeared is locallzed reglons and was not topperature-gradient dependent. The atrack varied in degree of severity from ouly slight 

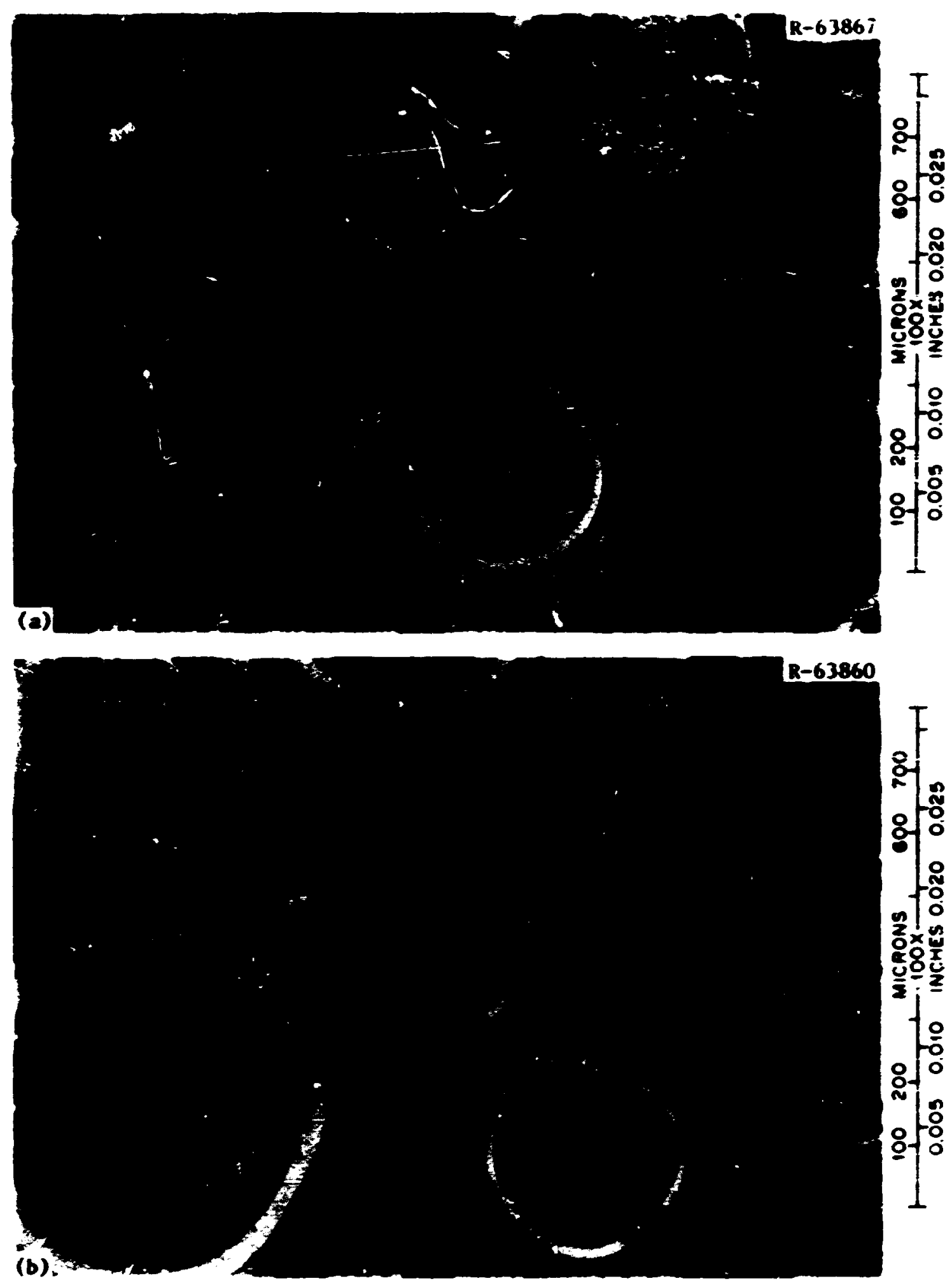

P12. 26. Srpical Areas from (a) Rod $3 C$ and (b) lod 30 Irradiated in Hab-4 Showlag gatled Outer LTI Layers of T=1so Coatings on Inert and pissile Kernels. The kerne!s aissing from the Triso coatings were lost during anple preparation. 


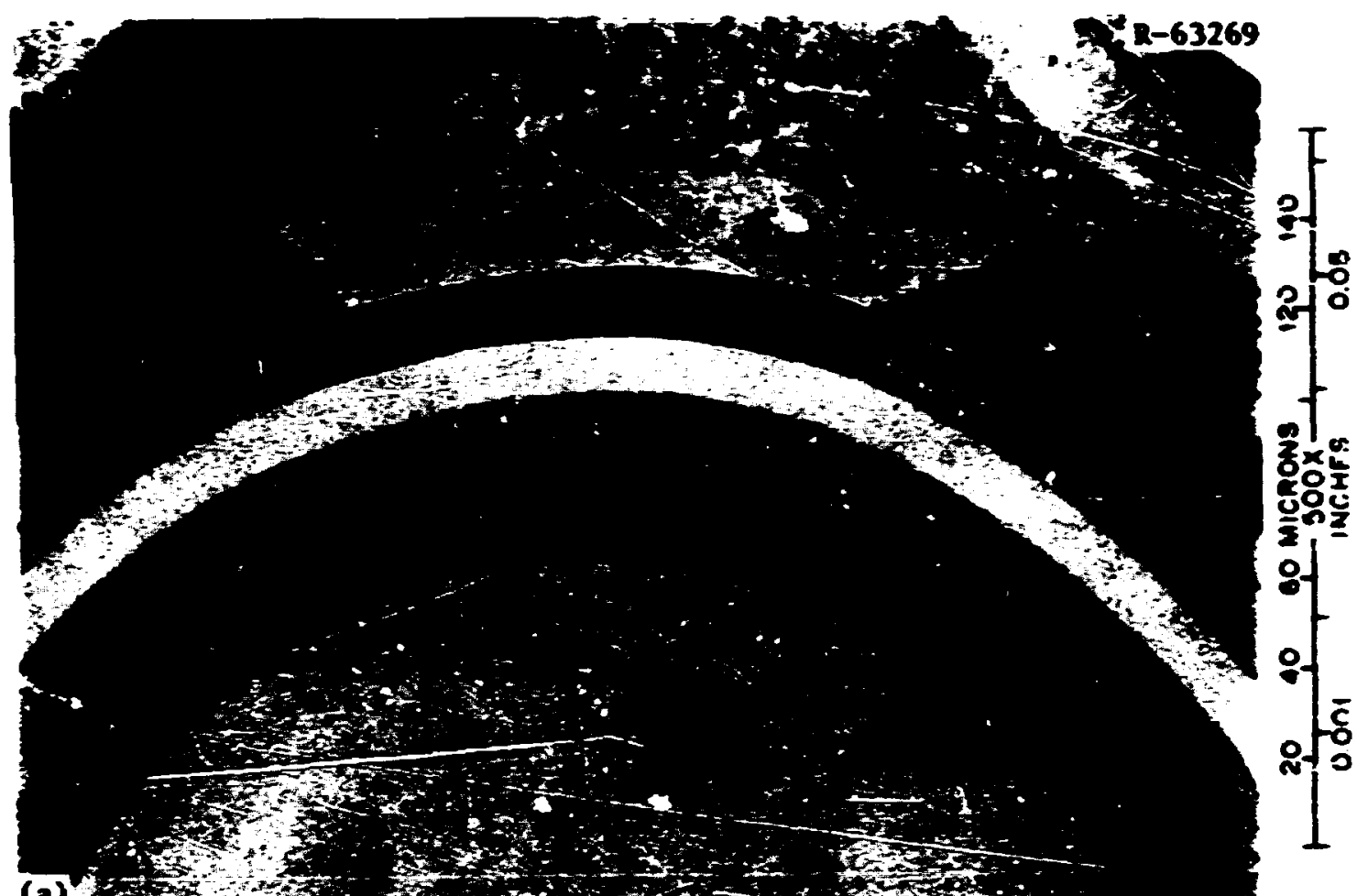

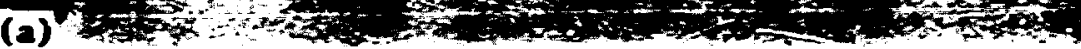

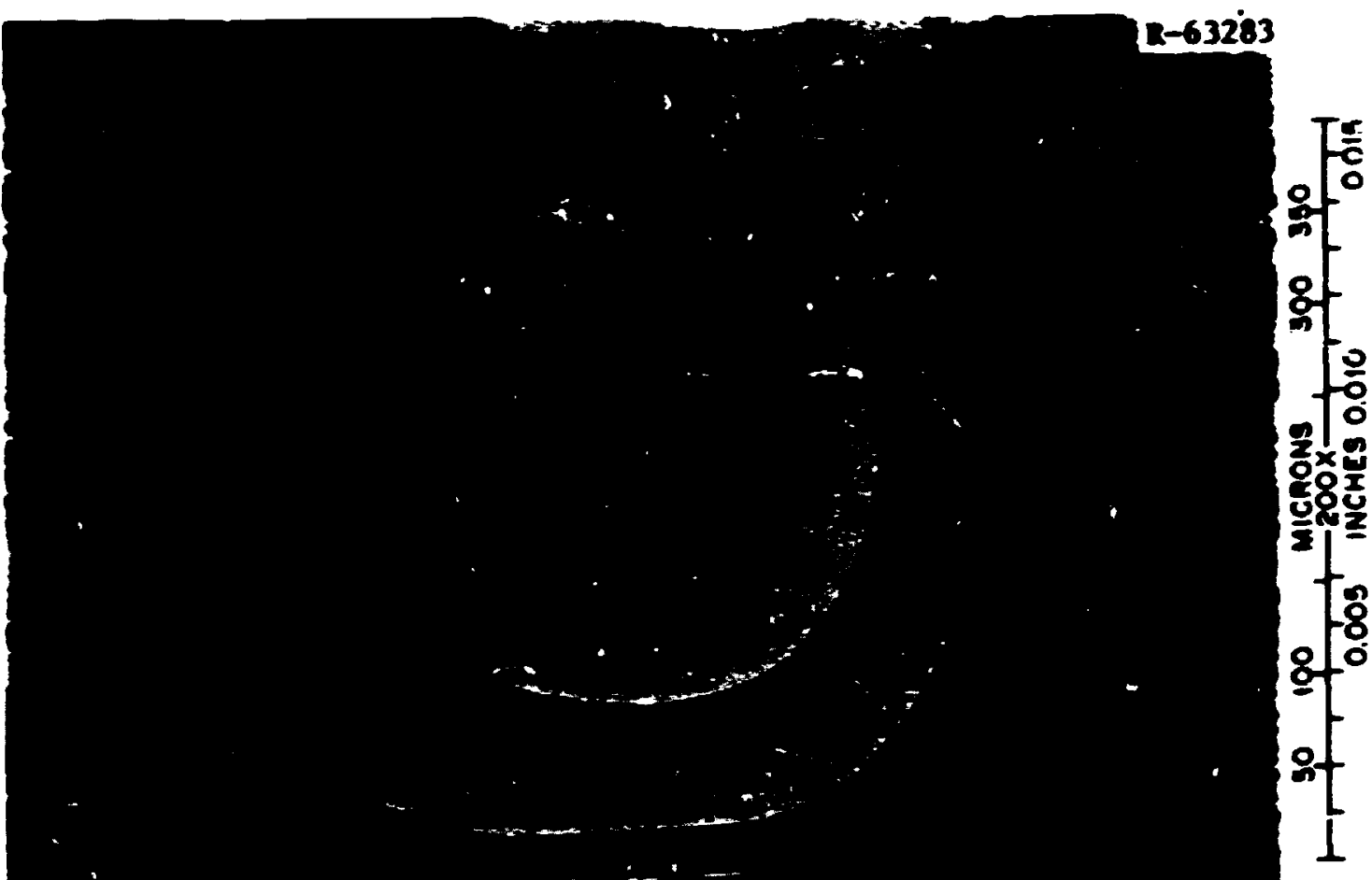

(b) $-6+2=$

P1s. 27. Falled (a) Trfeo and (b) Biso Coacings on Inert Rernels That Palled Becmise of Matrix-Particle Interaction in Rods Carbonized in Graphite Tibes. 


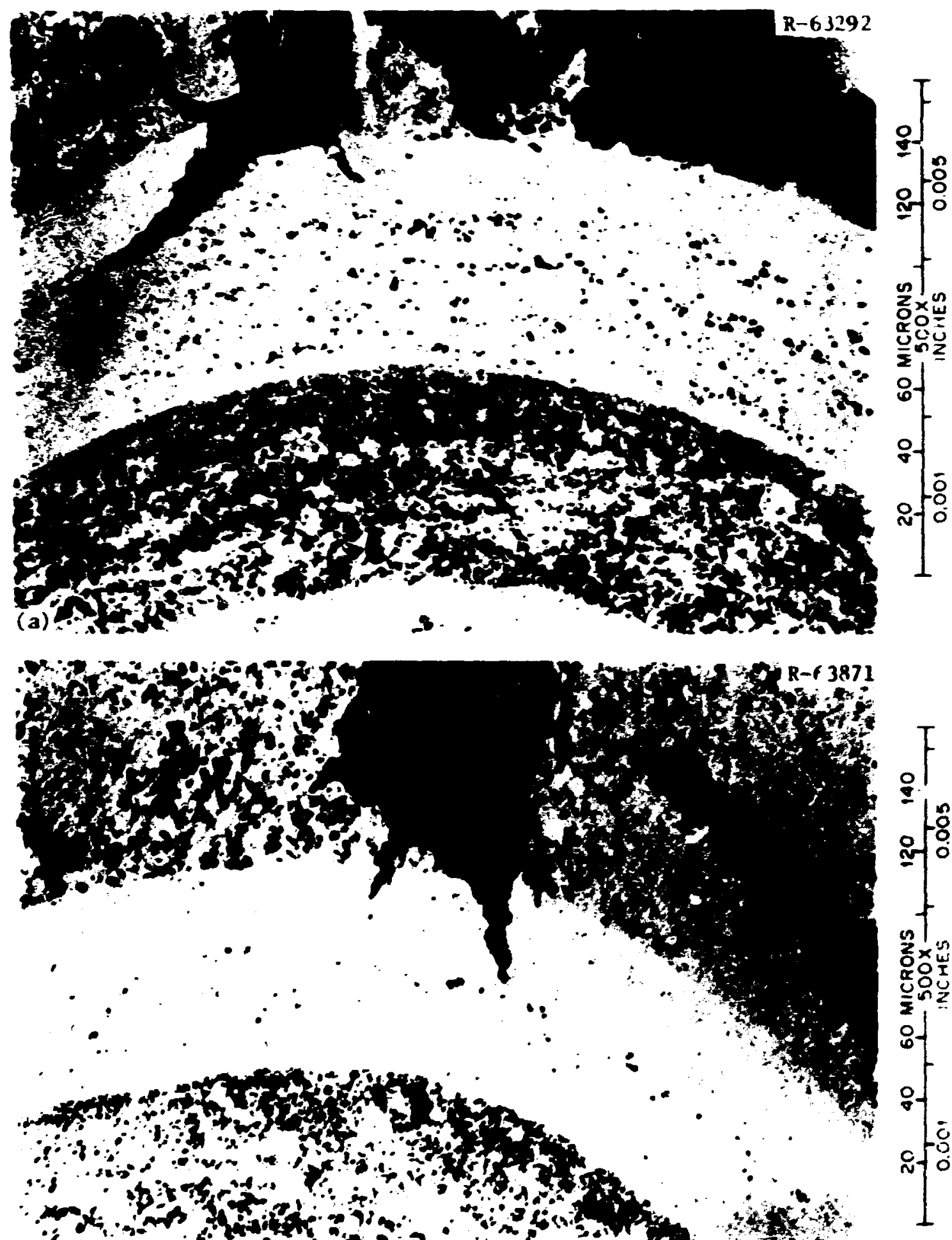

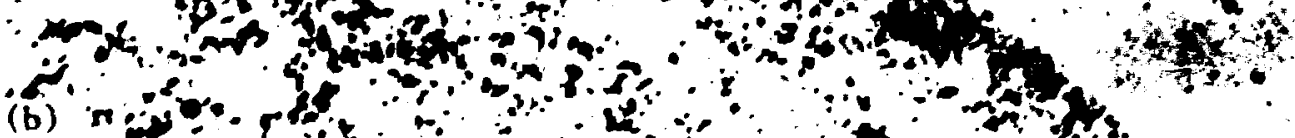

i18. 2․ Eiataples of the More Severely Danaged 31 so Contins. of Fetclle Particles Contained in Rods Carbonized in Ciraphitc: Tubes.

(a) From HRB-5, rod 3ij. (h) From HPB-\%, rod 3r. 


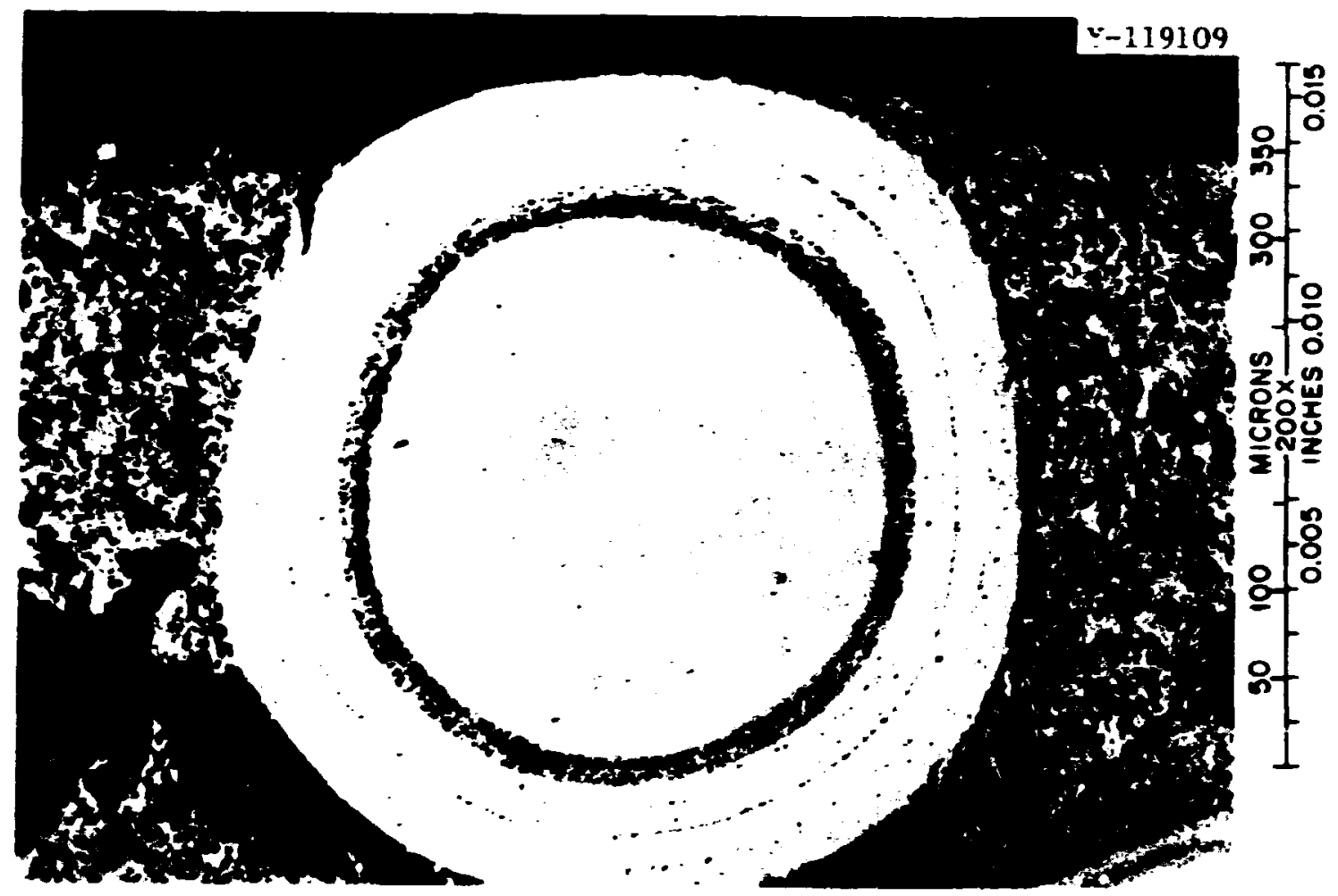

Fig. 29. Unirradiated Triso-Coated Particle in As-Fabricated Control Fuel Rod 3D. Note small tears in the peripheral region of the oucer coating. 


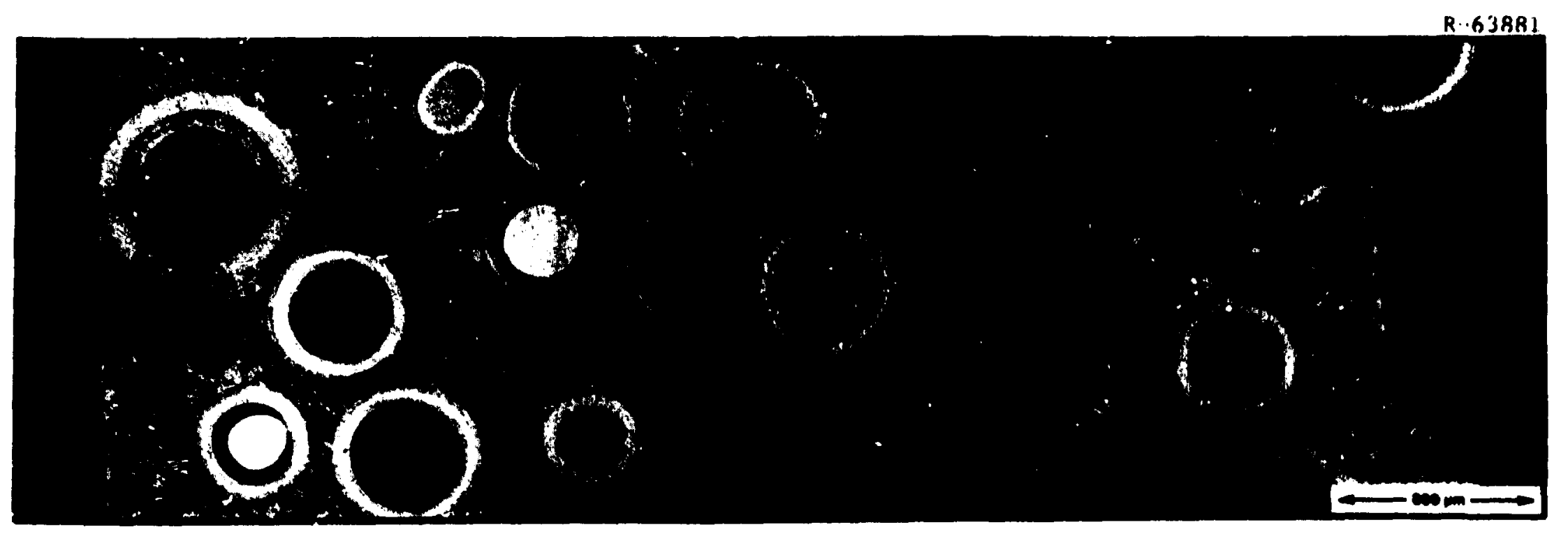

Fig. 30. Radial Seceion Through Extruded Fuel Rod Specimen IC Irradiated in HRB-4. Th1s fuel rod contained Triso-coated weak-acid rasin fissile particlea, Bloo-coated ThO 2 tertile particlea, and Tr18o and Biso Inert particlea bonded with Robinson graphitized coke and Varcum and carbontzed in a covered graphite tray. 


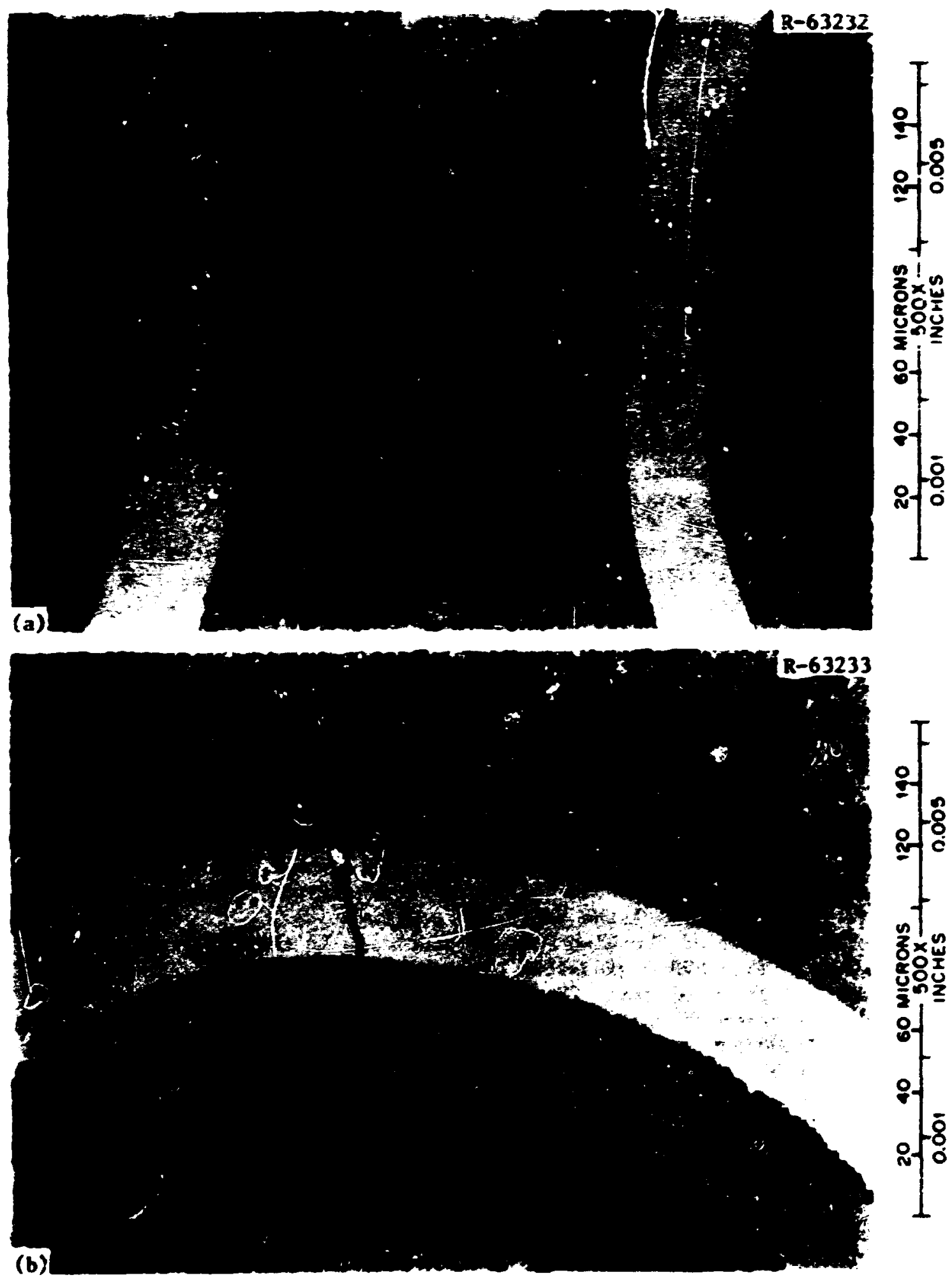

P18. 31. Triso Costings with Cracked S1C Layers in Extruded Puel Rod 1C, HRB-4. (a) Cracked SiC. (b) Cracked SIC and Inner LTI layer. 
to conlete penetration of the thickness of the SiC. A general degradation of the imer surface of the SIC was also apparent in any of the coated particles. Analysis of a region of attack with the aid of an electron aicroprobe revealed the fission product palladiu to be the culprit. The results of this analysis are shown in Fig. 32. The attacked regions appeared to have been witen. A palladiu-silicon phase diagra show three eutectics that have welting points belou the surface temerature of the fuel rods $\left(15.5 \% \mathrm{Pd}, \mathrm{pp} 800^{\circ} \mathrm{C}\right.$; approxientely $457 \mathrm{Pd}$, op $720^{\circ} \mathrm{C}$; $58 \mathrm{Pd}$, ap $850^{\circ} \mathrm{C}$ ). ${ }^{11}$ This result would be atypical of HTor conditions, since the bulk of the pallatiun present was a fission product fro ${ }^{23} \mathrm{Pu}$ and not ${ }^{235 \mathrm{~J}}$ (the $\mathrm{OC} 2$ was enriched to about $6 x^{235}$ ). However, this result could become significant should a decision be ande to incorporate plutonius in the HTGR fuel cycle.

In addition to the above problen, about one-fourth of the $\mathrm{UC}_{2}$ kermels appear to have phase segregation and were in intinate contact with the Inver LII coating, and a metallic-like Ingos had attacked the SiC coating. Although no SiC coatings had falled as a result, up to one-half the thickness of the SIC appeared to have been dissolved by the netallic-like aterial; one such particle is show in Fig. 33; the results from in electron aicroprobe analysis are shown in Fig. 34. The rare earths La, Ce, Pr, and ind were the fisston products associated with the localized dissolution of the SiC layer. Note also that uraniun was not associated with this reaction zone and that there is no obvious concentration of silicon in the kernel.

The rare-earth fission products were also found concentrated on the Inner surface of the cuoler side of the SIC coating, as has been reported in other coated-particle systens that have been exposed to a thernal gradient. 12 The presence of the rare earths led to penetration of about half the thickness of the SIC coating; both rare-earth and palladiu attacks are show in F18. 35. The fissile kernels vere varted in appearance, and it is therefore not possible to show a "typical" particle; some of the types of particles eranined from BRB-4 are show in F48. 36. Generally, except for kernels that reacted with the SiC, the kernel and buffer layer densifled, creating a gap at the inner surface of the inner LTI coating.

The kernels of the Biso fertile particles in the slug-injecied fuel rod $3 A$ from HRB-4 exhibited a slight "anoeba" effect. The $\mathrm{ThO}_{2}$ kernels had migrated about $20 \mathrm{\mu m}$ [F18. 37(a)]. Although there was no neasurable novement of the $\mathrm{ThO}_{2}$ kernels in the other three fuel rods, the densified-buffer recoll zone was noticeably darker on the hot side of the kernel in rod 3B [F18. 37(b)]. An electron nicroprobe analysis was unable to detect any chenical difference between the hot and cold alde of the buffar layer.

'Max Hansen, Constitution of Binary AlLoys, 2nd ed., McGraw-H111, New York, 1958, p. 1126.

12 RTGR Base Program Quart. Progr. Rep. May 31, 1973, GULF-GA-A12599, Pp. $87-93$. 

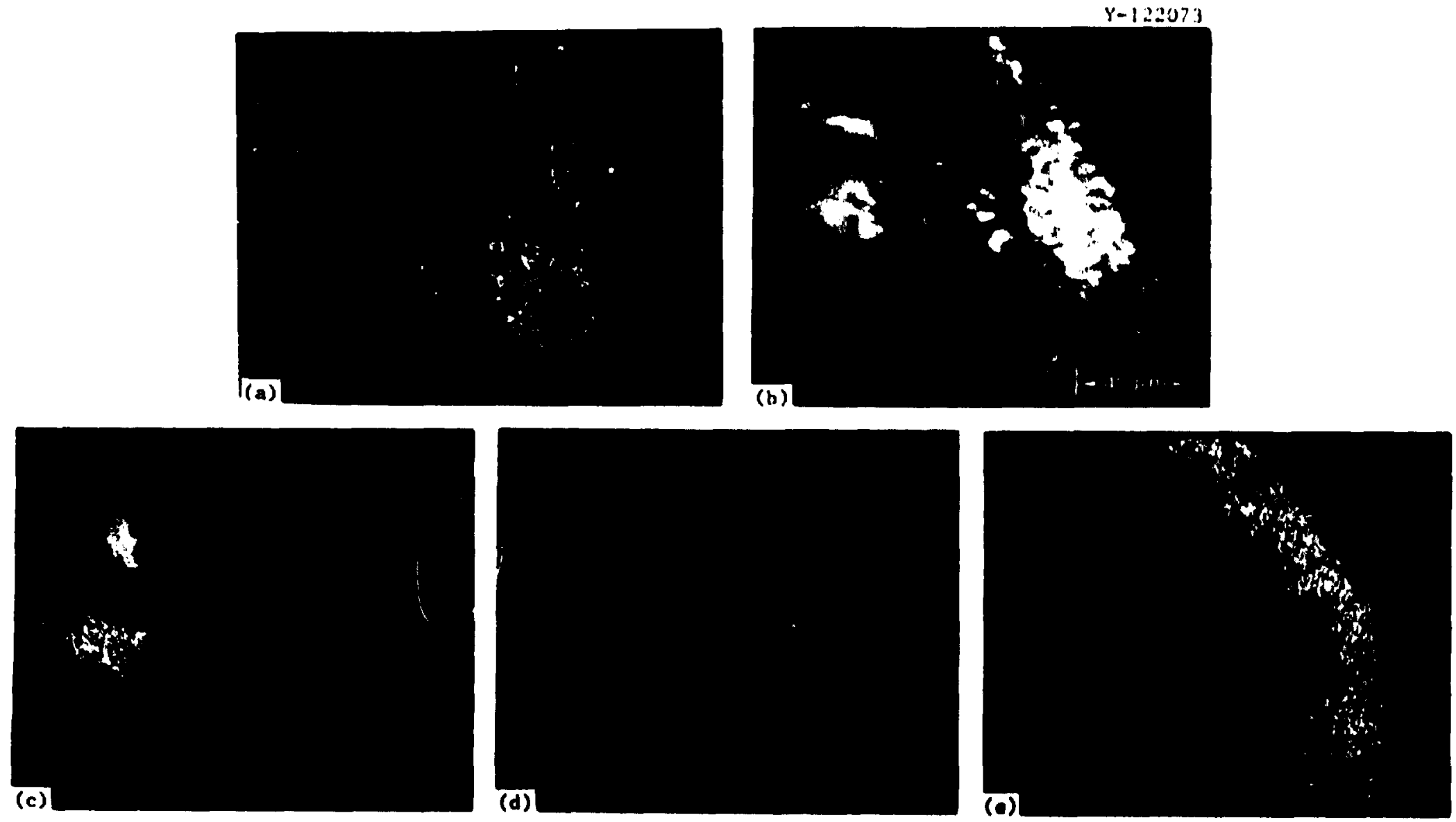

F18. 32. Palladium-SiC Reaction in a Triso-Coated waR Fiasile Particle Contained in rual Rod 3A, HRB-4, as Displayed by Electron Microprobe. (a) Optical micrograph. (b) Backecattered electrone. (c) $U M_{B} \cdot$ (d) $P d L_{\alpha} \cdot$ (e) $S 1 K_{\alpha}$. 

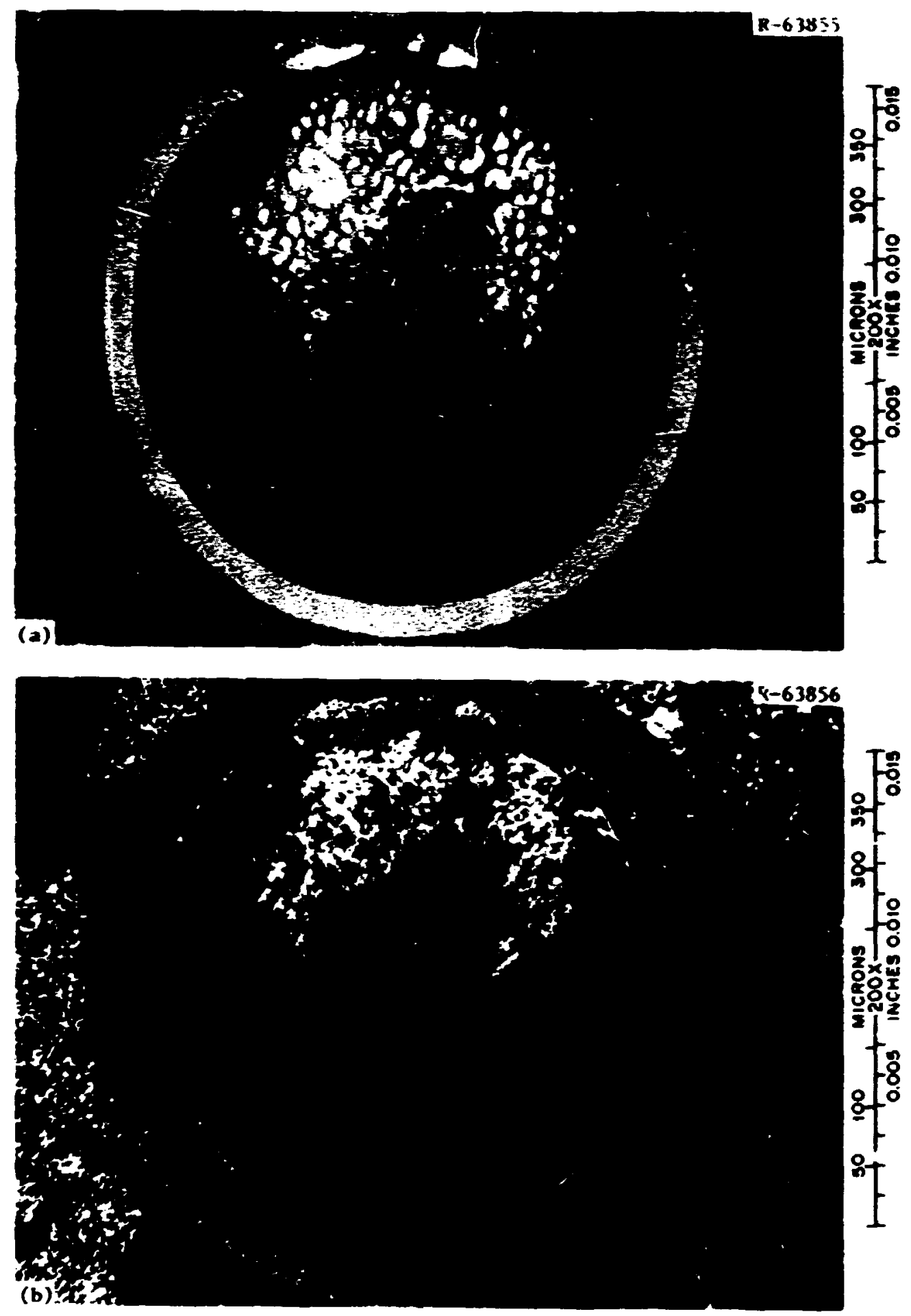

P18. 33. Triso-Coated WAk Pisslle Particle in Slug-Injected Puel Rod 3B, HRB-4, Showing Chentcal Interactions Between Kernel and Coatings. (a) Bright field. (b) Polarized light. 

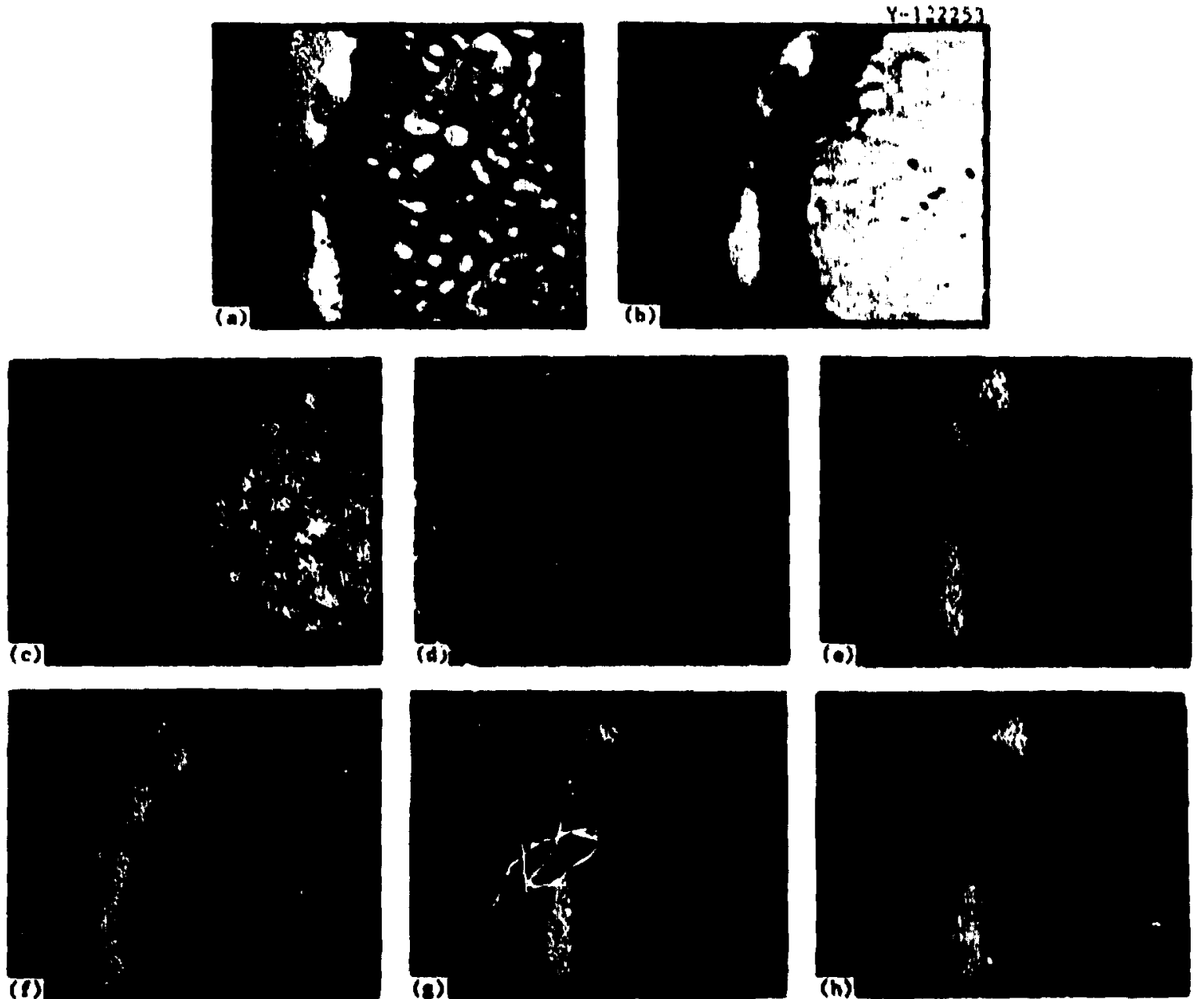

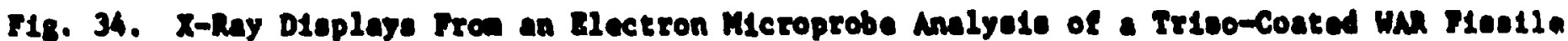
Particle Contained in Fuel Rod 38, HRe-4. Note chenical atteck of 81C Layer by rare-earth fleeton producta Ce. Nd, La, and Pr. (a) Optical photograph. (b) Backecatterad electrona. (c) $U M_{\alpha}$. (d) La La. (e) Pr La. (t) Si La. (s) Ce La. (h) Nd La. 


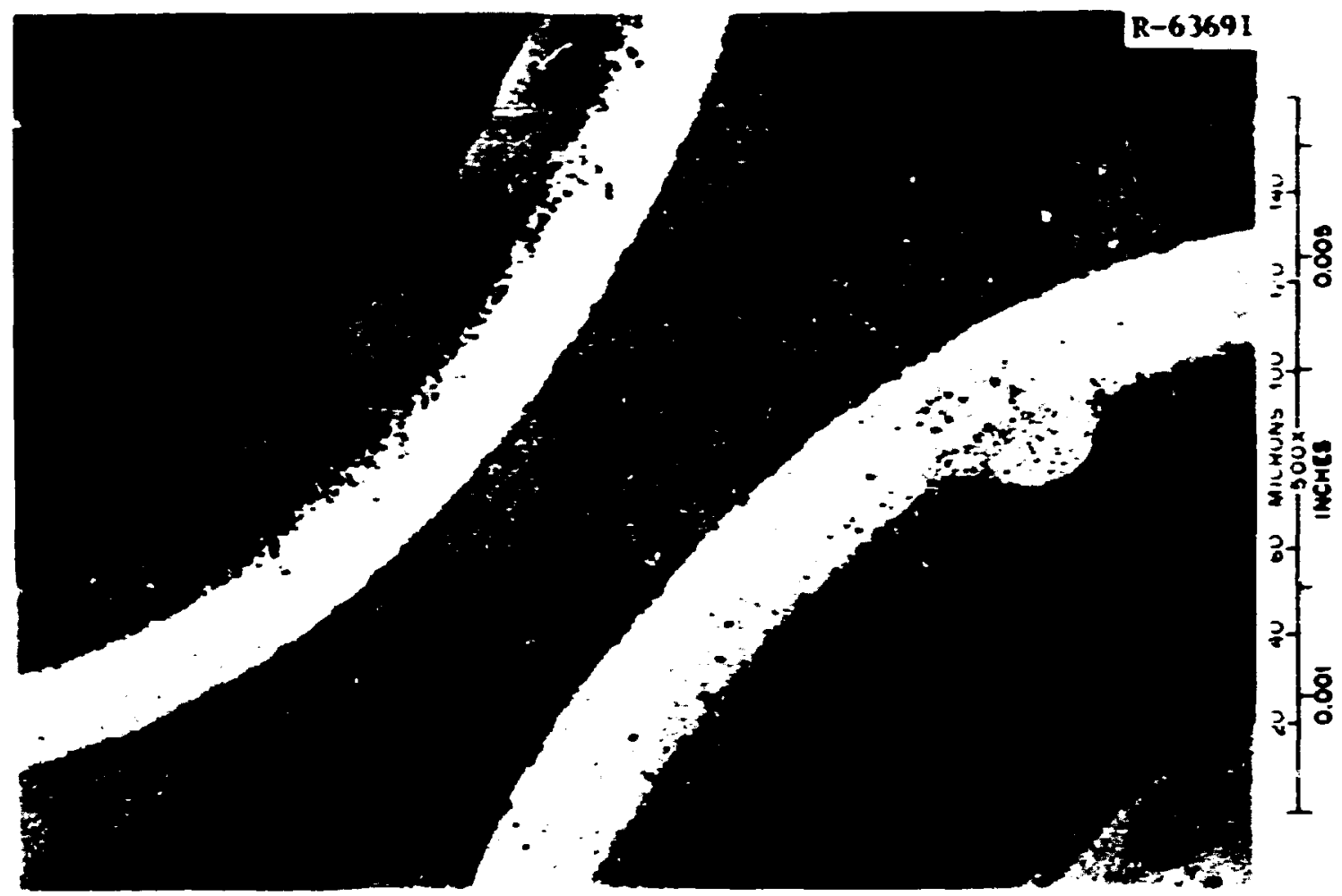

Fig. 35. Triso Coatings on war Fissile Particles Irradiated in HRB-4. The SIC coating on the left shows the result of attack by rare-earth fission products on the cold side of the particle. The SiC coating on the right shows attack by palladiue. 

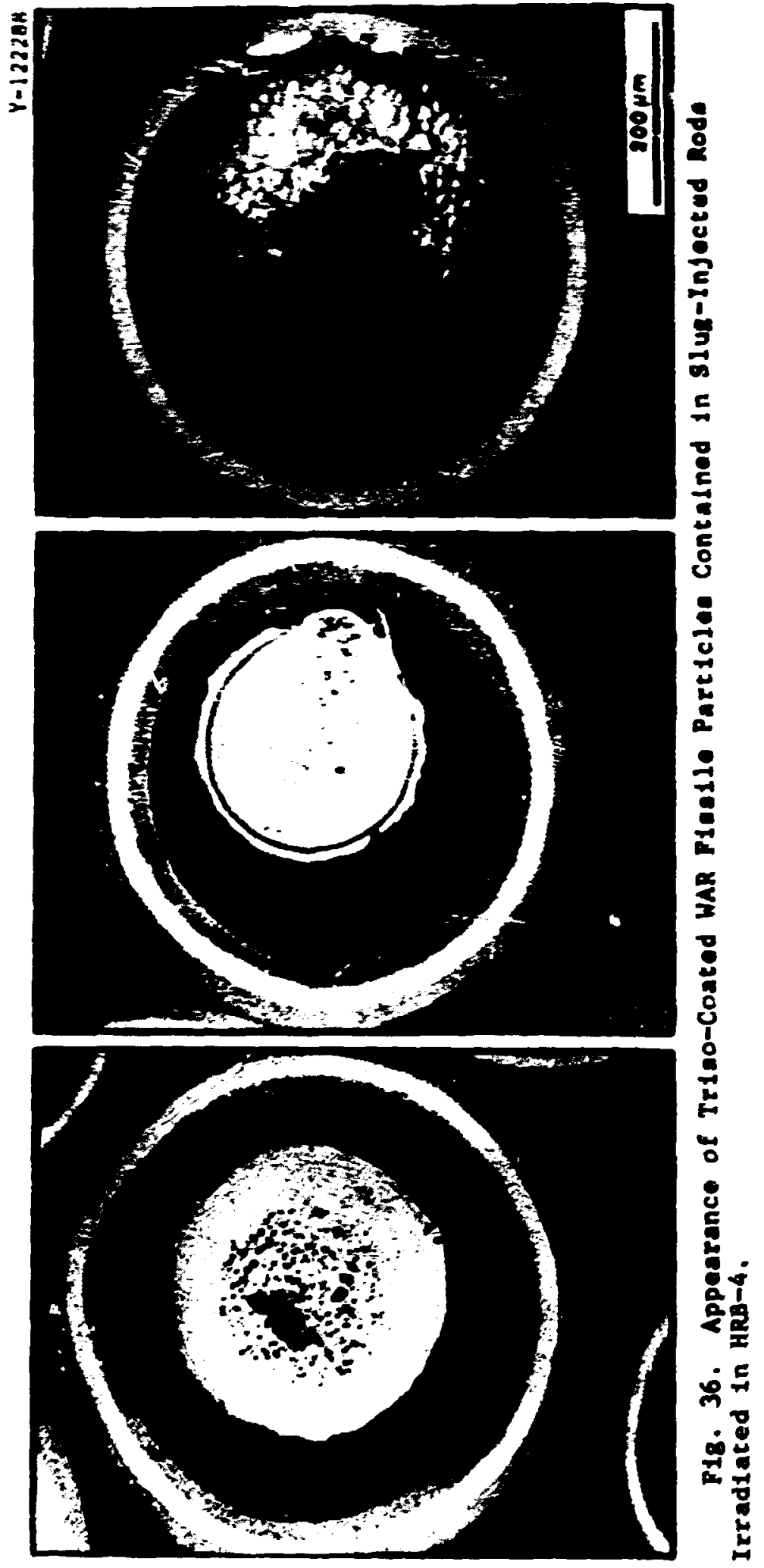

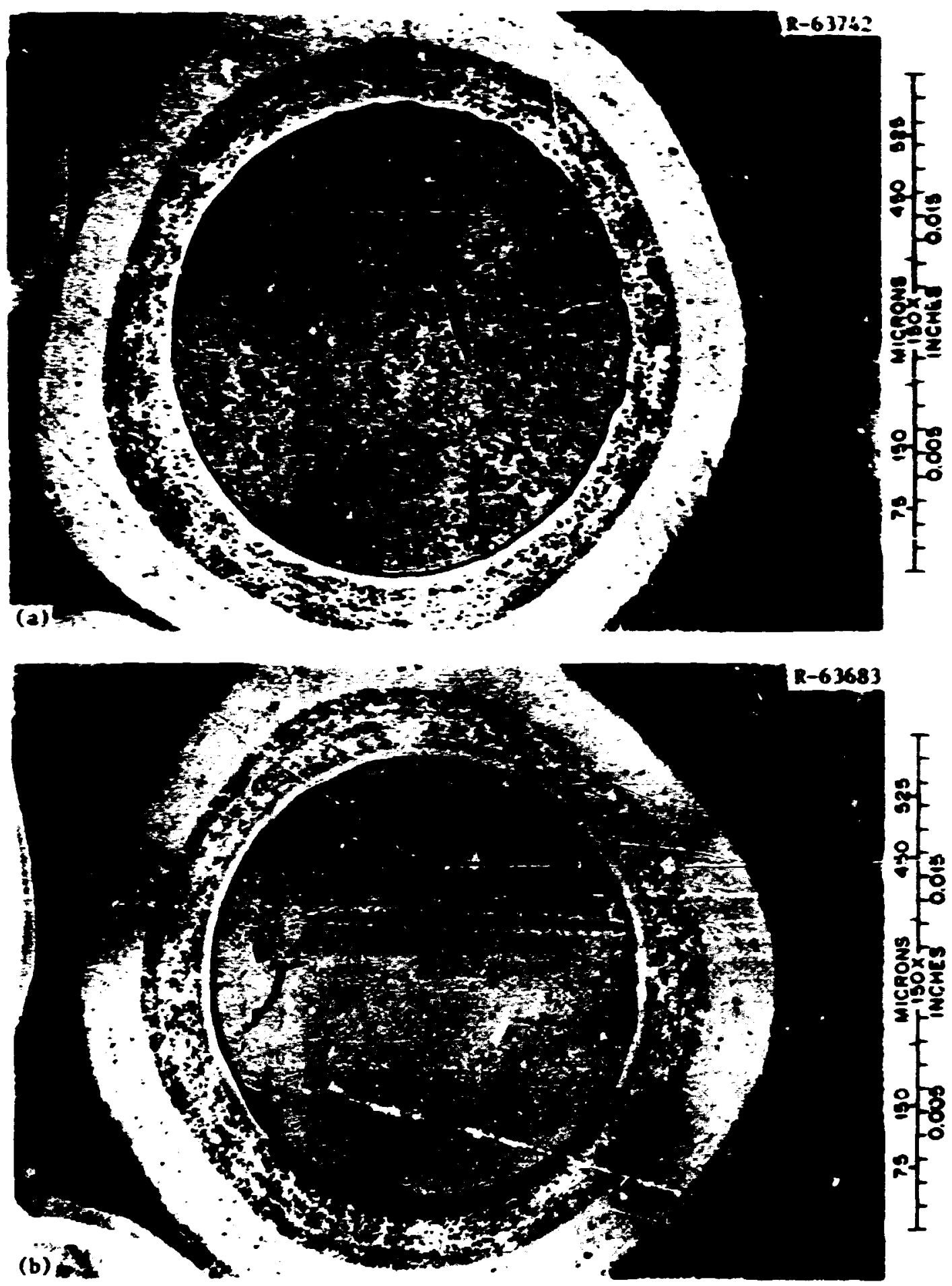

Pig. 37. Biso-Coated ThO Fertile Particles in Slug-Injected Fuel Rods 3A and 3B Irradiated in HRB-4. (a) Rod 3A. Note migration of $\mathrm{ThO}_{2}$ kernel - hot side of particle is on the right. (b) Rod 3B. Note dark region in butfer on hot side (bottom) of the kernel. 
The extruled rods operated at a higber heat rating and in a higher flux than dit the slug-injected rods. Bowerer, the overall te-perature of the extruded red was lover than that of the sIog-injection rods because of the hagher atrix density. Mecallography showed that the iNP. kermels had densified, as expected (Fig. 39); bet in concrast to the fissile particles in the slug-injected rods, there was no coidence of fission product atzack on the SIC layers. Drentantion of the fertile particles stwowed is evidence of the "moebs" effect or indication of pocential fallure.

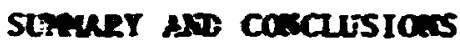

trib-4 and -5 were the first tests of weak-acid-resio-derived fisolle fuel. Approxinately atme monts after tie completion of this test, the win ilssile fuel ws eelected as the refereace resycle fissile kerwel, replacing the dease aixed oxice kernel. The decision uas ade on the basis of the perfornare of the une kerwels in wou-s and -5 . The good behaviog of war fuel in Gac irradiactions tests (P13P) ${ }^{13}$ was also a factor in the decision to ake this fuel the reference recycle kernel.

The prinary deficleacy in the dense alxed on:-" kerwel was che noeba effect, or thermal algration of the kermeliz up the teaperature gradient. This effect was not presenc in the UAR kernels irradiated in His-4 and -5 . There uas scee concentration of fisston products at the inner SiC boundary, prinarily Pd, Ce, Pr, in, aed mi. Thelds of Fd from Pu fissions are bightier by a factcy of 8 than from ${ }^{23} \mathrm{~J}$ or ${ }^{23} \mathrm{U}$ fissfons. The ind-4 and -5 fuel was only partially eniched (about $6-77^{235} \mathrm{U}$ ) compared with the fully eariched aterial which vill be used in HTGks. Therefore, Pd vill not be a problea. The yields of the rare-earth fission products (Ce, Pr, La, and ad) are about the sae for Pu and $U$ fisstons, but subsequent irtadiations have showr that these fission products can be retalned in tive kernels in oxide farm ity adjustnent of the initial kernel stoichionetry.

A sigaificant abservation fron the HRB-4 and -5 tests was the interaction between particit and atrix in the specinens carbonized In graphite tubes. Appareatly the cuter coatinga of sone particles were torn wray due to a strong bond between particle and atrix and irradiat ion-induced shrinkage of both coetings and antrix. This problew, which was first identified by the HRE -4 and -5 experiexce, has recelved considerable atcention in the Thorfun Uedization Progran development work subsequent to this experisent. The particle-aatrix interaction is thought to be dependent upon pitch-coke yields during carbontistion, on the anunt and distribution of wacro- and microporostty, and on the atrength of the coatings themselizes. In HRB-4 and -5 the worst cases of particle-macrix interaction were noted in specimens which had the : sest frartion of atcroporosity after fabrication. These sug-injected specimens aiso had the highest aacrix density and the highest pitch-coke yleld. The crush strength values reported in

${ }^{13}$ HTGR Base Progrom Puart. Progr. Rep. Mag 21, 1974, GULF-GA-Al 3030 , Pp. 9-8 through 9-20. 

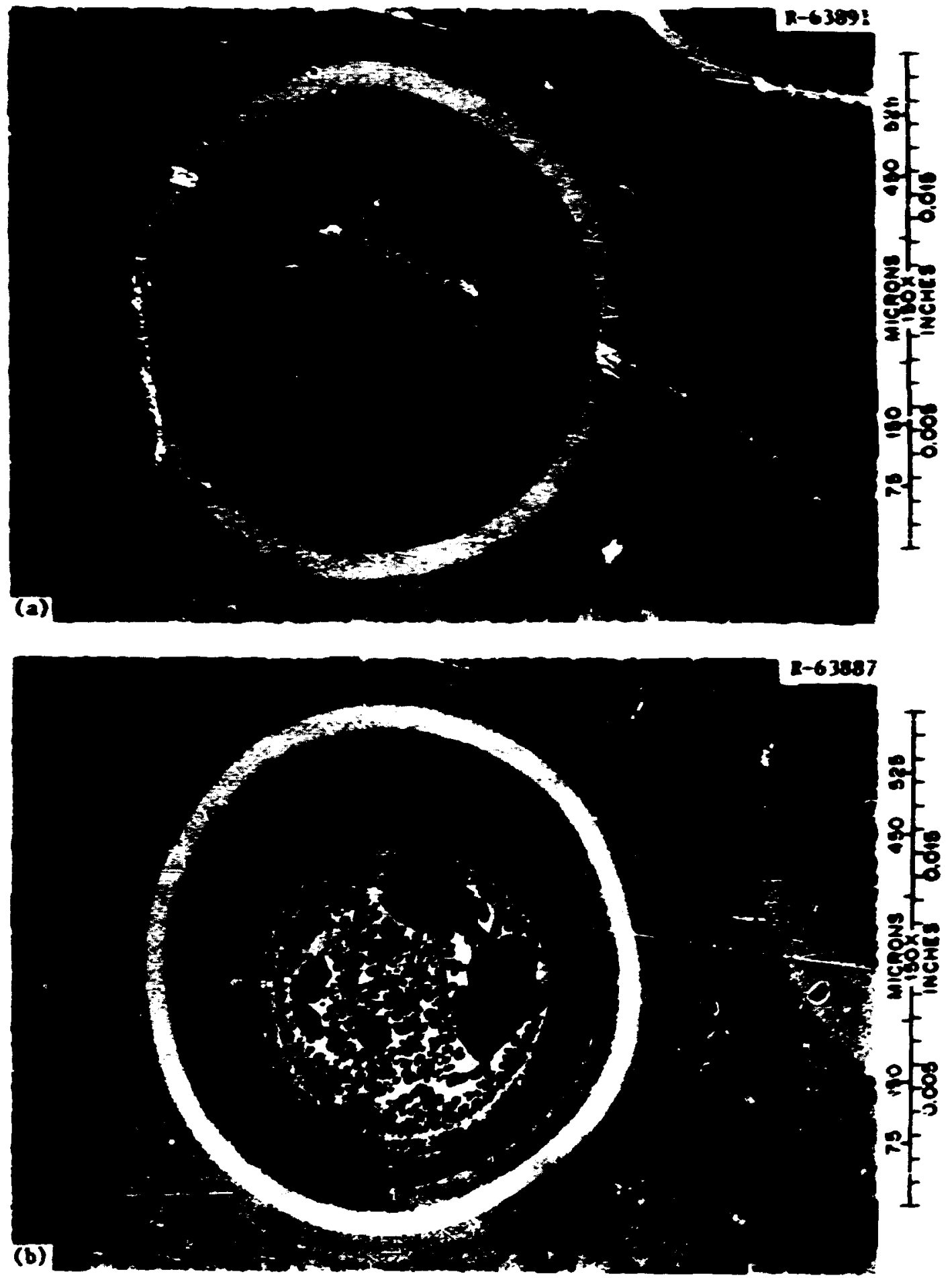

118. 38. Appearance of Typical Triso-Costed UAR P1ssile Particles In Puel Rod 1C Irradiated in unb-4. Mnte kernel and buffer have densifled but there is no esidence of aigrat!on or fission product attack. 
Table 3 are typical for fistle and fertile particles. The crush streagths of che faert particles may be a litele low, but this does ne necessarily reflect "weak" courines, because the coating thickresses are lou compred with the chichoesses on the fissile and fercile particles. Hech progress bs been ade in woterstandine the merix-particle interac: fon protlen, an potential solutiose are beine checked in adictomol irradiacion cests.

The performance of the extroled fuel sods in wo-t acd -5 vas genersily good. Only eight excrubed foel rodo have been cested sin the

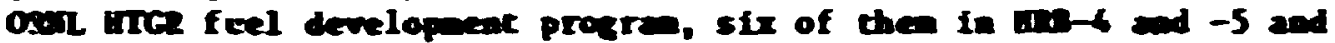
the reminimz 500 in min-6. The appearace of the extruded rods in 100-4 and -5 after irrediation was very $800 d$ - better than the ppearance of che slug-injected rods. The presence of sall cracks in the SiC layer after fabrication susests that the fabrication rechaiques for extruded fuel require additionai developnent. Onfortuantely, the scope and foding level of the 0 ill progra bave not fermitced adiitional developent of extrusfoe techaclogy bejoed that has beep demertrzeci in an-4, -5 , and -6 .

The dinensical behavior of the foel rod specinens in wo-t and -5 was about what was expected from the results cbrained in previous experineacs. The anistropic behavior of the slug-iajected fuel rods above a fast fluence of $6.5 \times 10^{21}$ neutrons/ on was someutat surprising, since it had been thought that the dinensional changes in these highparticle-wolume rods would be costrolled by the dimensiomal changes in the particles thenselves, and would therefore be isotropic. Hourever, it is now chought that the particles shrink aray fros the atrix, and at higi exposures the dimensional changes are caused by the atrix itself.

All of the experinental objectives of HRB-4 and -5 were net exceft one - the measurement of fuel centerline changes and monitoring the change in thermal conductivity with irradiation for the extruded fuel rods. This was coi accomplished due to the severe decalibration of the centerline thernometers. Analytical wethods ars bein investigated for correction of the thenometer readings, and if these nethods are successful, the last objective may still be met.

\section{ACONOWLDGAENTS}

The suthors wish to acknowledge the efforts of any people who axde significan: contributions tn the planning, execution, and evaluation of this irradiation test. W. P. Eatherly and J. L. Scott of the Metals and Ceramics Division and $J$. A. Conlin of the Reactor Divisinn participated in the plannine and design of the experiment. Conlin also assisted in the construction of the capsule; Scote and Eatherly also participated in the evaluation of results. R. A. Bradley and W. H. Miller, Jr., of the Metals and Ceranics Division, fabricated and characterized the sluginjected flel rods. J M kobbins and D. E. Rosson of the Metals and Ceramics Division fabricated and characterized the extruded rods. The fissile and fertile particles were coated and characterized by C. B. Pollock, formerly of the Metals and Ceramics Division. The 
dosinetry and thernometry for shese capsules were provided by H. T. Kerr of the Reactor Division and R. L. Sheperd of the Instruentak ien and Controls Division. The metallography of the unirrodiated loose particles and fuel rods was perforwed br $\boldsymbol{H}$. D. Allen of the General Metallography group, and the remote metallotraphy was performed by F. X. Atchley and L. C. Shrader of the Radiacion and Elertron Metallography group of the retals and Ceratios Evivion. The electror afcioprobe malyses were perforned by T. J. Heneon of the Iadiasion and Elestron Hetaliographsroup of ths Matals and Cernafes Division. The authors also acknouludge che assistace of R. B. Parker for technical editing and Julle Bishop fcr typing and makeup of the report. 
APPEXDII

Thereal Analyeis 


\section{APPEIDIX}

Thernsl Analysis

The calculated specisen fission heat rates and operating temperatures have already been presented in this report. This Appendix will present some of the backup information used in anking these calculations. As indicated previously, hirs capsules contaia a maber of Chronel-Almel thernocouples in the graphite sleeve. One of these thernocouples is seiected to control the terperatures of the capaules. In HRs-4 and -5 the thernocouple selected was $\mathrm{N}_{0}$. 7. adjacent to specisen 4B. In operating HRS-4 and -5 it was desired to keep the tenperature of the graphice midvall between 900 and $940^{\circ} \mathrm{C}$ in order for the funl specsinens to operate at their design teaperatures. Due to the increase in the fission beat rate during each cycle, control was waincained by reducting the theraal resistance across the fuel-graphite gap and the graphitestainlese steel gap, with increasing heat rate. This was done by varying the composition of the hellu-acon sweep gas. Early in the cycie, when the heac rates were low, a high concentration of Ion-conductivity neon was used in the sweep gas. As the heat rates increased, the concentrat:un of high-conductivity hel tun was lacreased. Krouledge of the exact composition of the sweep gas is necessary for accurate thenal analysis. Floweter data give indication of the gas composition, but detailed analysis of these data have shown ther to be unreliable. Also, the variation of theraal flux as a function of time at different axial posteion is not constant. Therefore, constant operating temperatures cannot be achieved for all specimens using this control procedure. This is evident from exanination of the curves in Figs. 6 and 9.

Data for sweep gan composicion vs the for HRb-S are presented in

Fig. A-1. This information 18 derived from floweter readings. No oweep gas data were taken during operation of HRb-4. There are gaps In the Hhs -s data where no readings were taken, and in sone req ions the data are inccasistent with the therwocouple resdings. For example, during cycle st? the flowmeter dats suggest a big change (10z increase) In the heliu content at day 9 . The thermosouple data suggest a much more modest change. Juring cycle 87 the floweter data suggest a $14 \mathrm{~K}$ increase in helitu content at day 20 . The thenocouple data reflect a much more modest shange.

The deficiencles noted with the HRB -4 and -5 sweep gas data caused some modifications to be made in the thermal analysis procedure. Three paraneters are of concern in the analysis - the graphite iduall teaperatures, the fuel specinen fission heat generation rate, and the sweep gas composition. With any two of these paraneters, the third can be calculated. Beginning with cycle 88 a modification was made in the way the capsules were operated. Time periods were interspersed throughout eech cycle where the oweep 8 as was 1007 hellu. This fixed one of the above-mentioned parameters. Knowing the graphite aldwall temperature during these periods permitted a calculation of the specimen heat generation rate. Assuminz that the change in heat rate was a smooth 
BLANK PAGE 
function of tine in the cycle, a curve was drawn. Fron this curve, a back calculation of the sweep gas compositions throughout the cycle was nade. Unfortunately, the interspersed periods of 1002 heliun opecation vere not available for cycles 83 through 87 . To permit use of the analytical techniques perfected for other capsules, the graphite aftrall teaperature profiles expected for 1007 hellin operation have been "dras" in as shown in the example given in Fig. A-2. The sweep gas compositions inferred by using this procedure are show in Figs. A-3 and -4 . Figure $A-4$ can be compared with Fig. A-1 for HRB-5. The compositions shown in Figs $A-3$ and -4 were used tc make the fuel surface and center teaperature calculat lons presented earlier in this report. Hithout accurate neasuzements of the fuel centerline temperatures, it is no: possible to deternine the precision of the calculated temperatures. Hovever, since each fuel specinen located adjacent to a graphite alduall thernocouple 18 treated in the same nanner, it is possible to use the agreenent between sweep gas compositions calculated for these specimens as a rough indicator of the precision of the calculations. Exmination of the plots shown in Figs. A-3 and -4 reveal that the $g a s$ compositions are usually within $\pm 2 \pi$ of each other, and always within $\pm 5 z$. This agreenent is considered to be "fair." Much better precistor, has been achieved in other experinents, where periods of operation with $100 \%$ heliu vere incerspersed anong periods of operation with aixed sweep gas. The errors assoclated with uncertainty in the sweep gas composition have been described.'

Additional information needed for the fuel temperature calculations includes the dinensional changes of the fuel rods and the graphite sleeve during irradiation. The dimensional behavior of the fuel rods was shown in Fig. 17. The pre- and postirradiation graphite sleeve dimensions are shown in Figs. A-5-A-8. As before, these figures show the increase in graphite dianeter over the minimu dianeter of 0.825 to $0.827 \mathrm{in}$. (for $0^{\circ}$ and $90^{\circ}$ orientation respectively). The fuel dimensional change data were fit to a parabola, and the graphite data vere fit to a straight line (linear swelling with fast fluence).

'F. J. homan, Thermal Analysis of $H^{m} G R$ Fuel Rods Imaaiated in the HFIR Removable Beryllium Facility, ORNL/TM report (In preparation). 


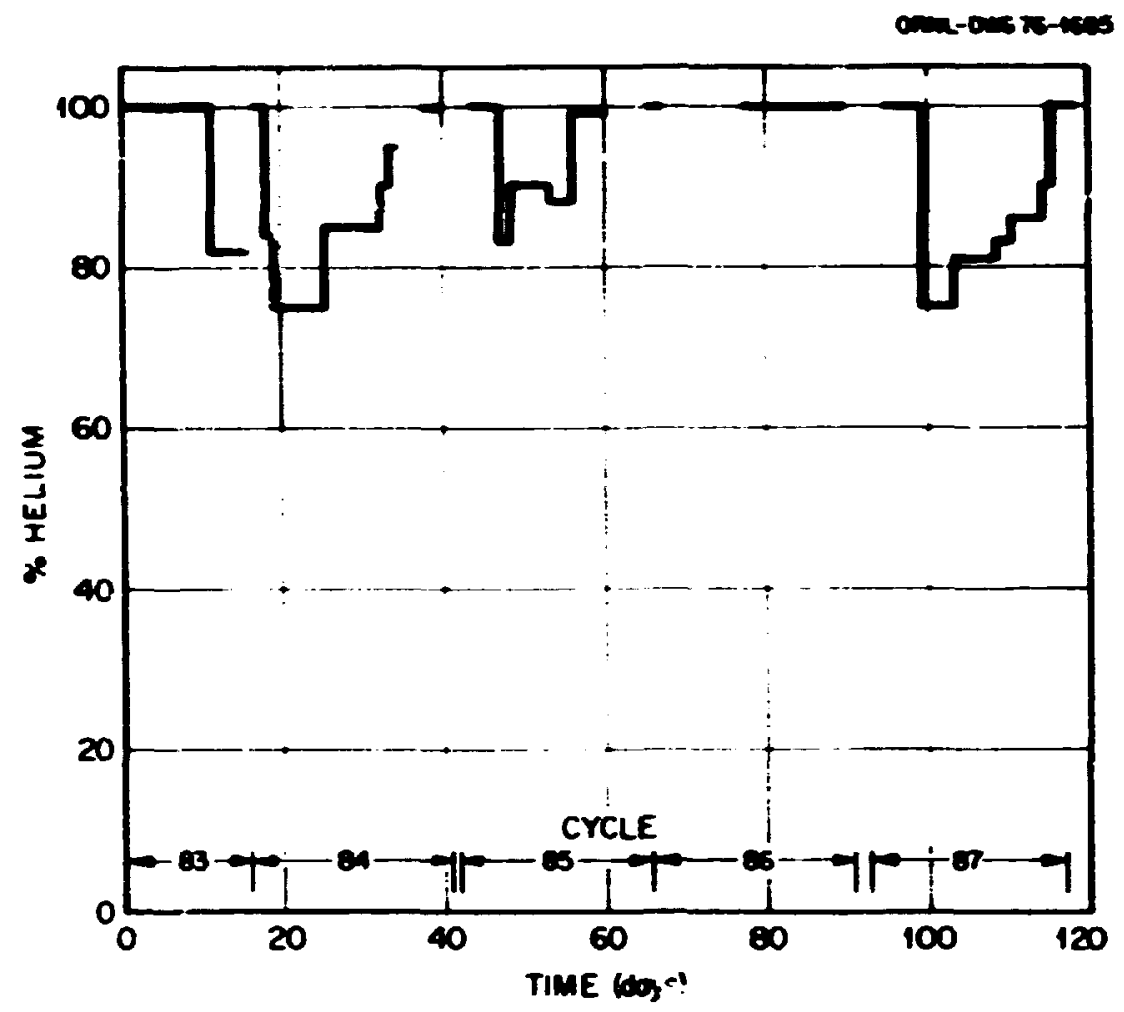

Fig. A-1. Helfum-lieon Sweep Gas Composition vs Tine in HRB-5.

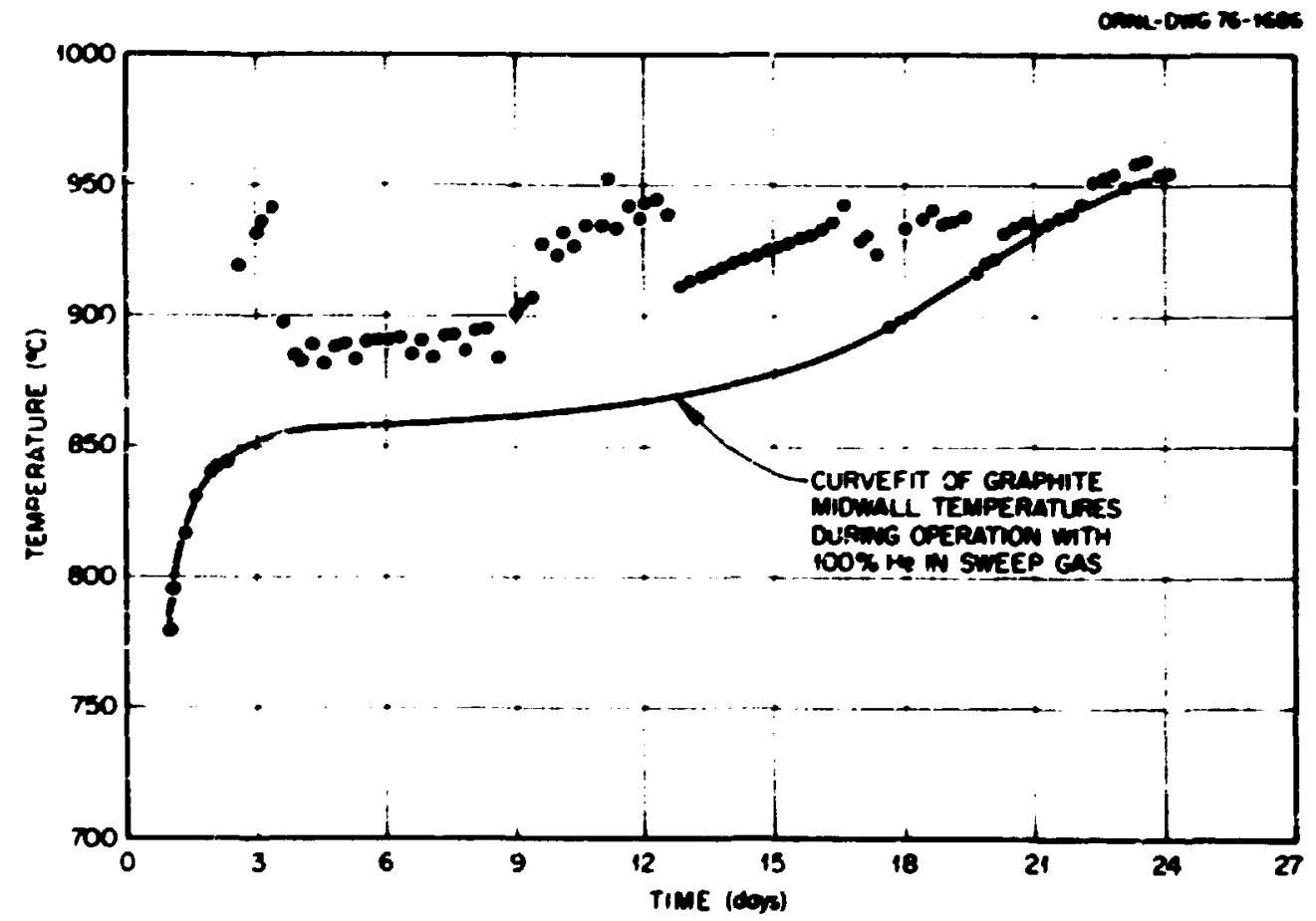

P1g. A-2. Temperature Readings for Therwocouple 7, HRB-4, During HFIR Cycle 85. 

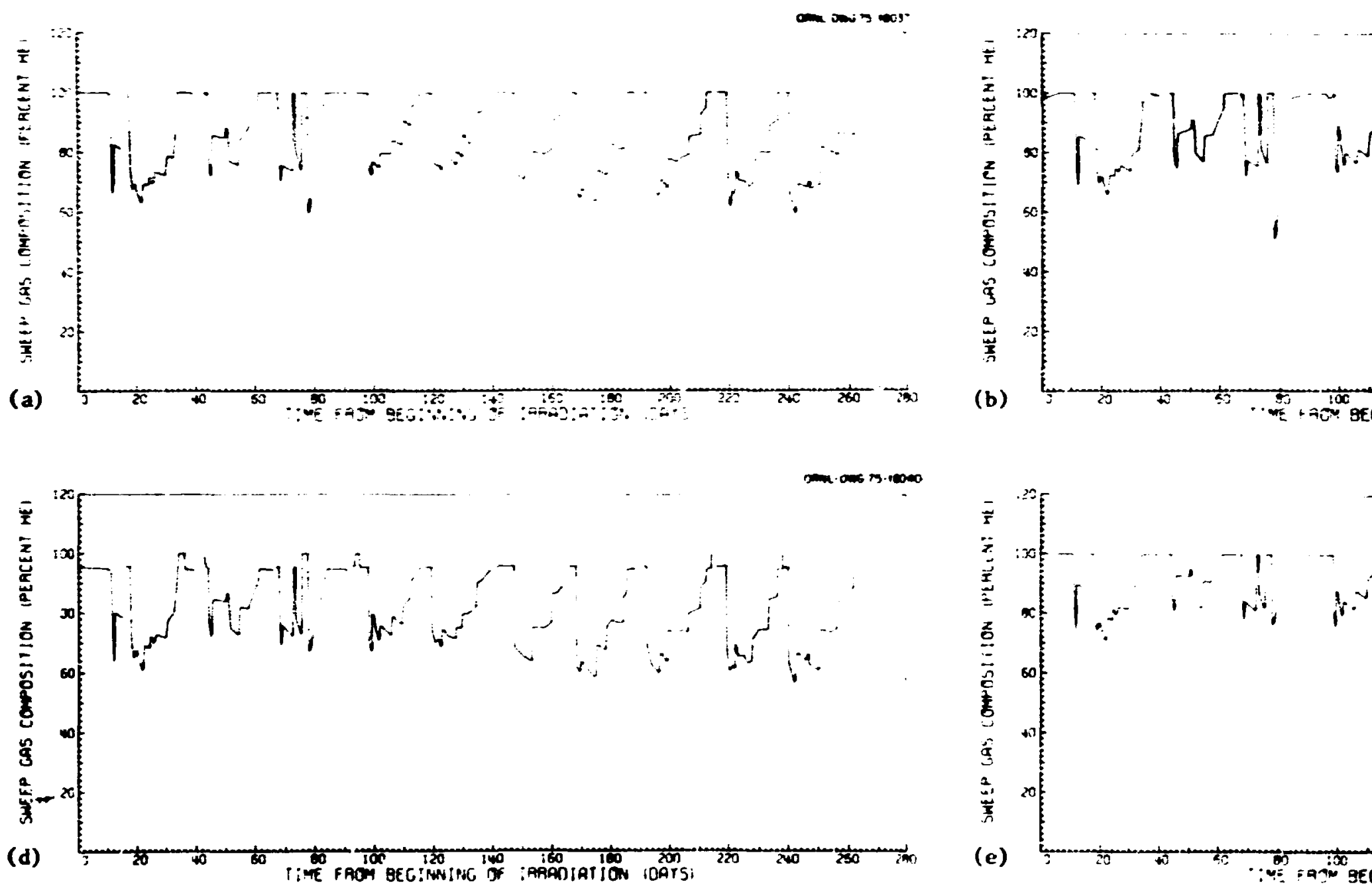

Fig. A-3. Calculated Sweep Gas Composition vs Time for 


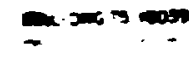

$1^{-1}$

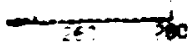

BLANK PAGE

$m+\cdots$

$-$

5 
64

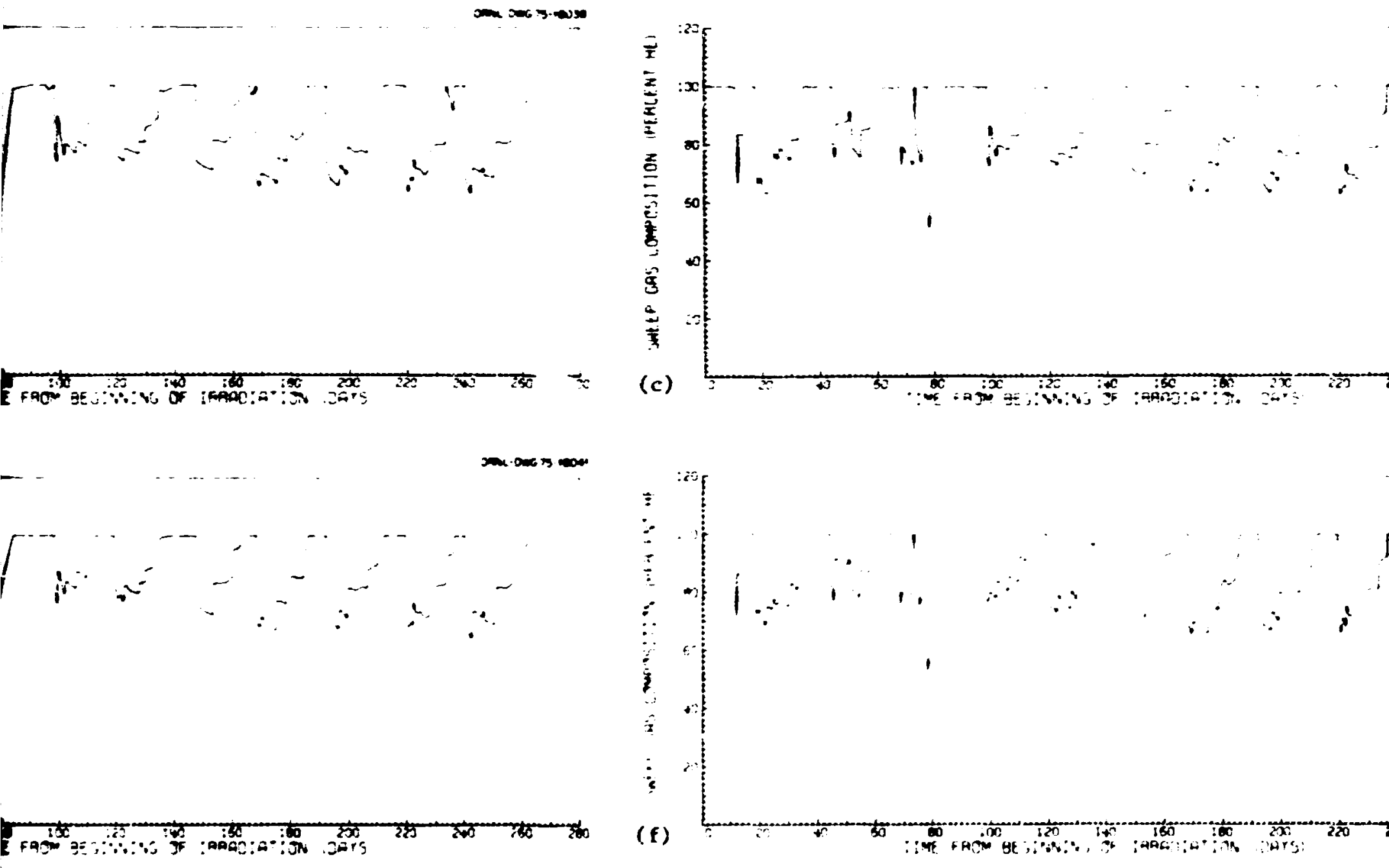

for $\mathrm{HKB}-4$ Specimens. (a) $1 \mathrm{~B}$, (b) $1 \mathrm{C}$, (c) $2 \mathrm{~B}$, (d) $3 \mathrm{~A}$, (e) $3 \mathrm{~B}$, (f) $4 \mathrm{~B}$. 


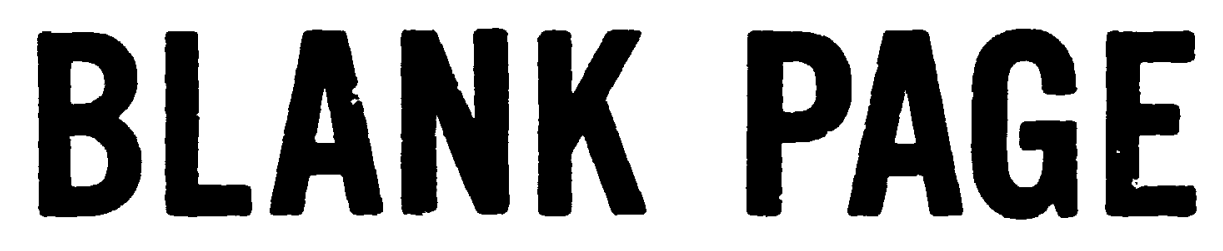



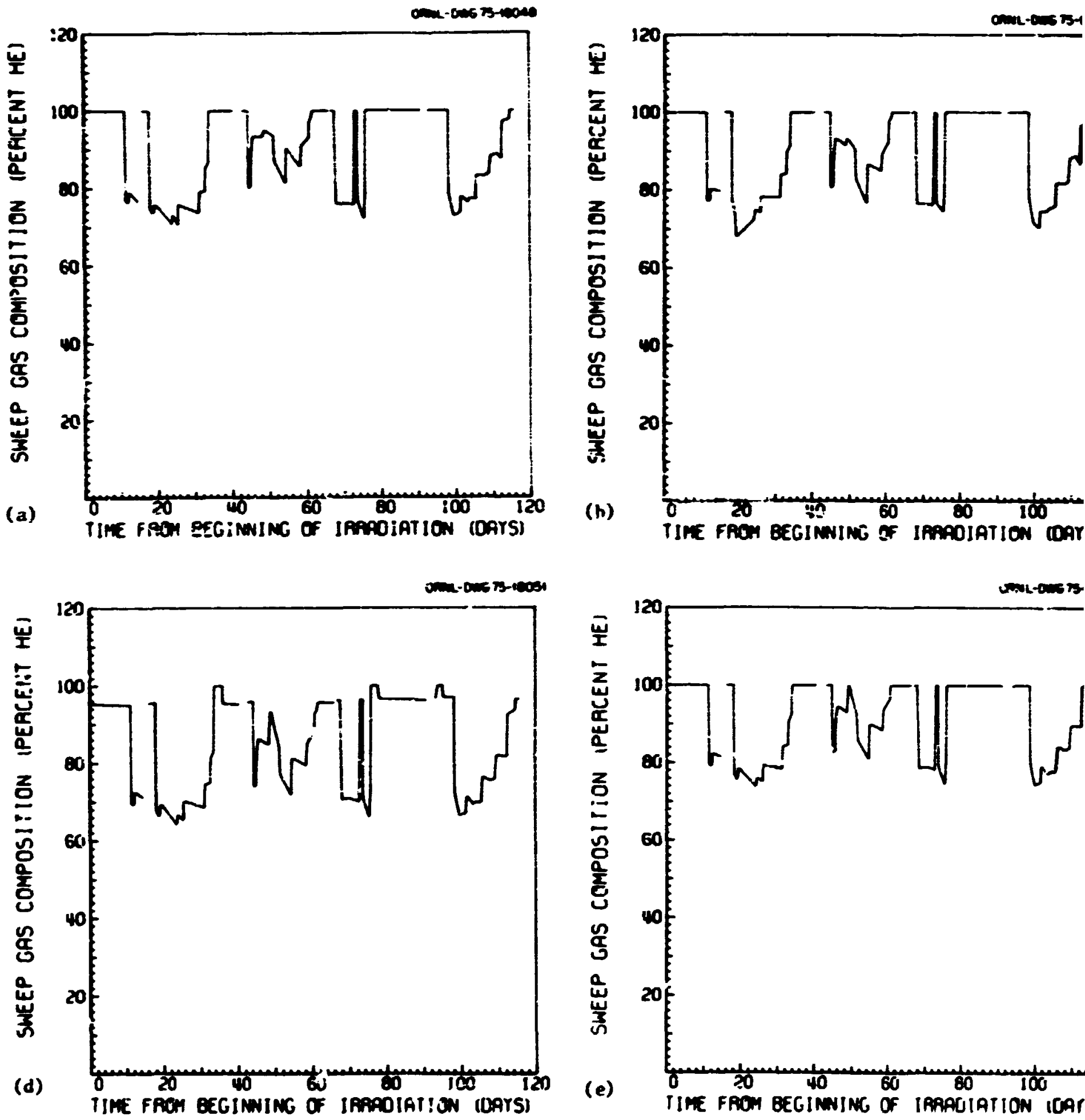

Fig. A-4. Calculated Sweep Cas Composition vs Time for HRB-S Specimpns.

(a) 1 
BLANK PAGE 


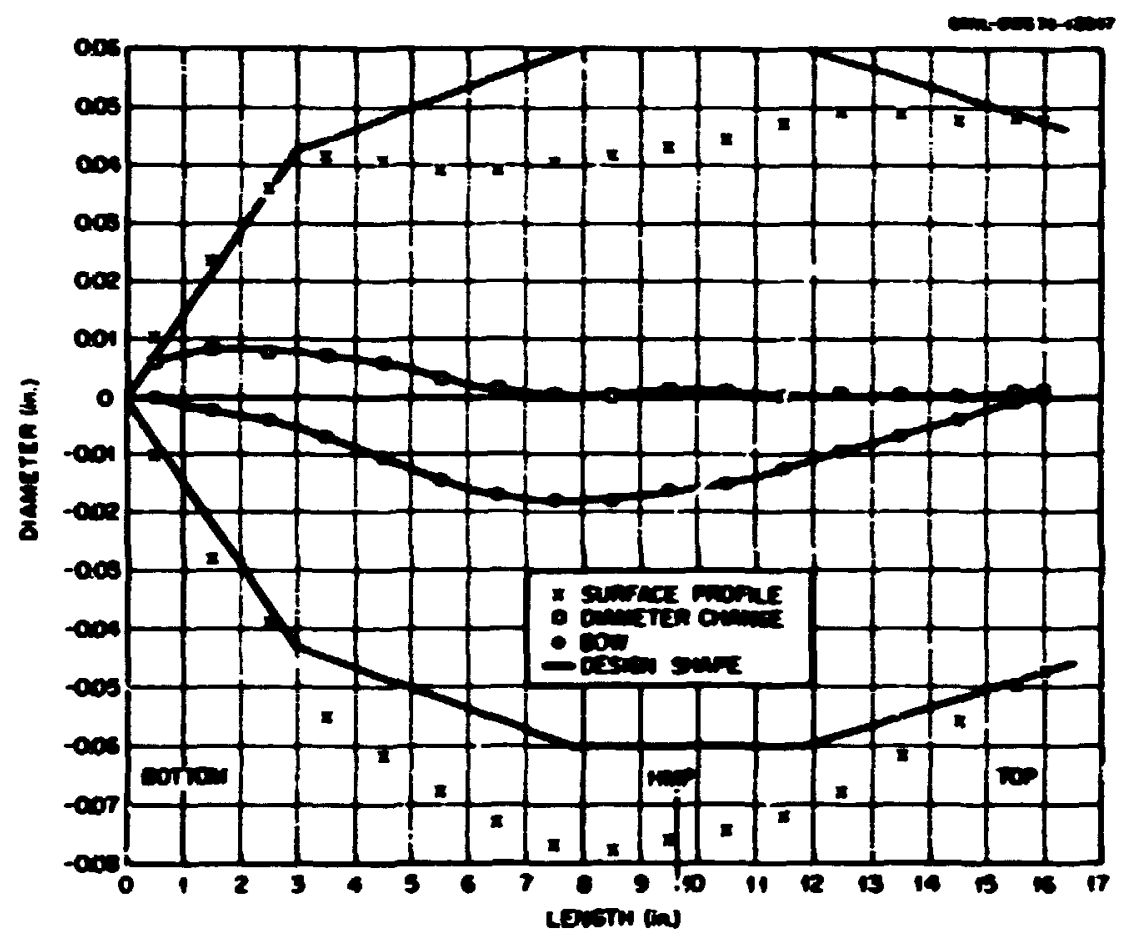

Fig. A-5. Graphite Sleeve Dinensions for Capsule HRB-4 $0^{\circ}$ Orientation.

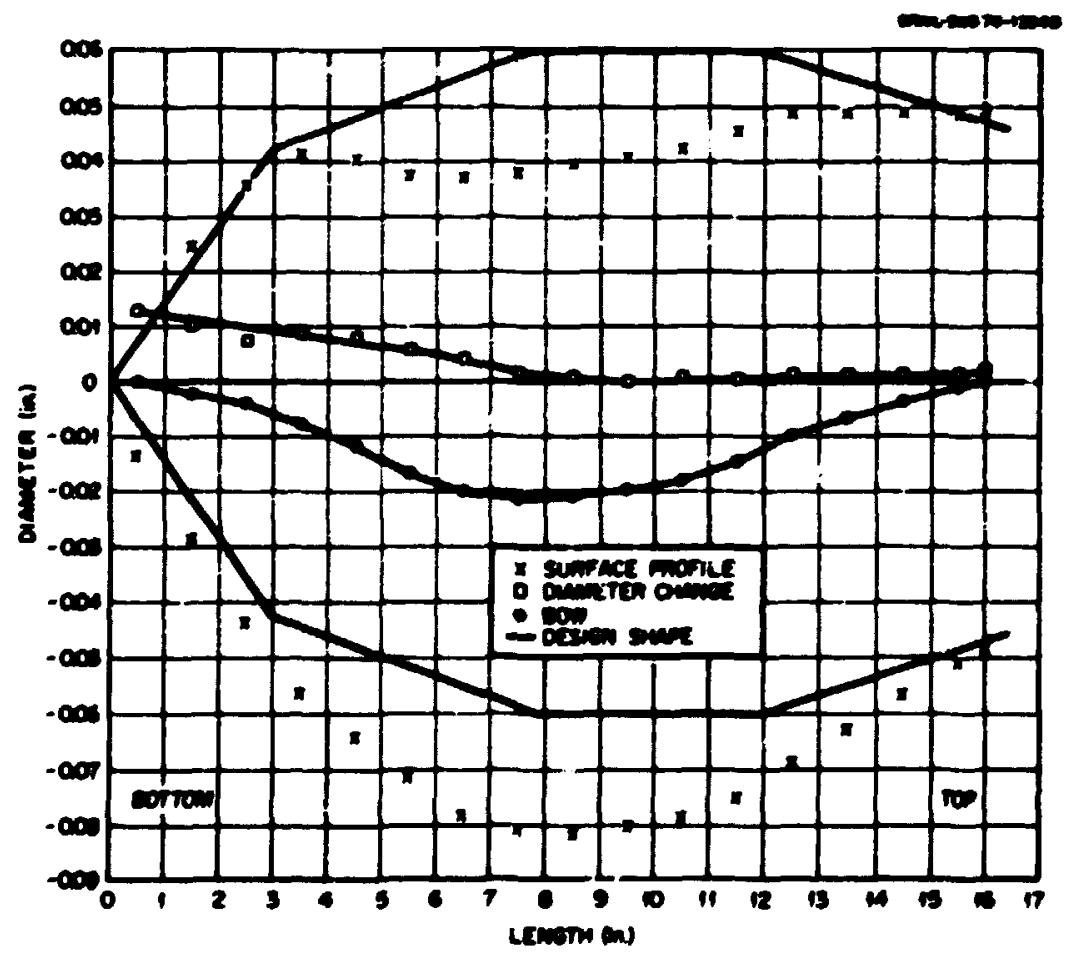

Fig. A-6. Graphtte Sleeve DI ensions for Capsule HRB-4 $90^{\circ}$ Ortentation. 


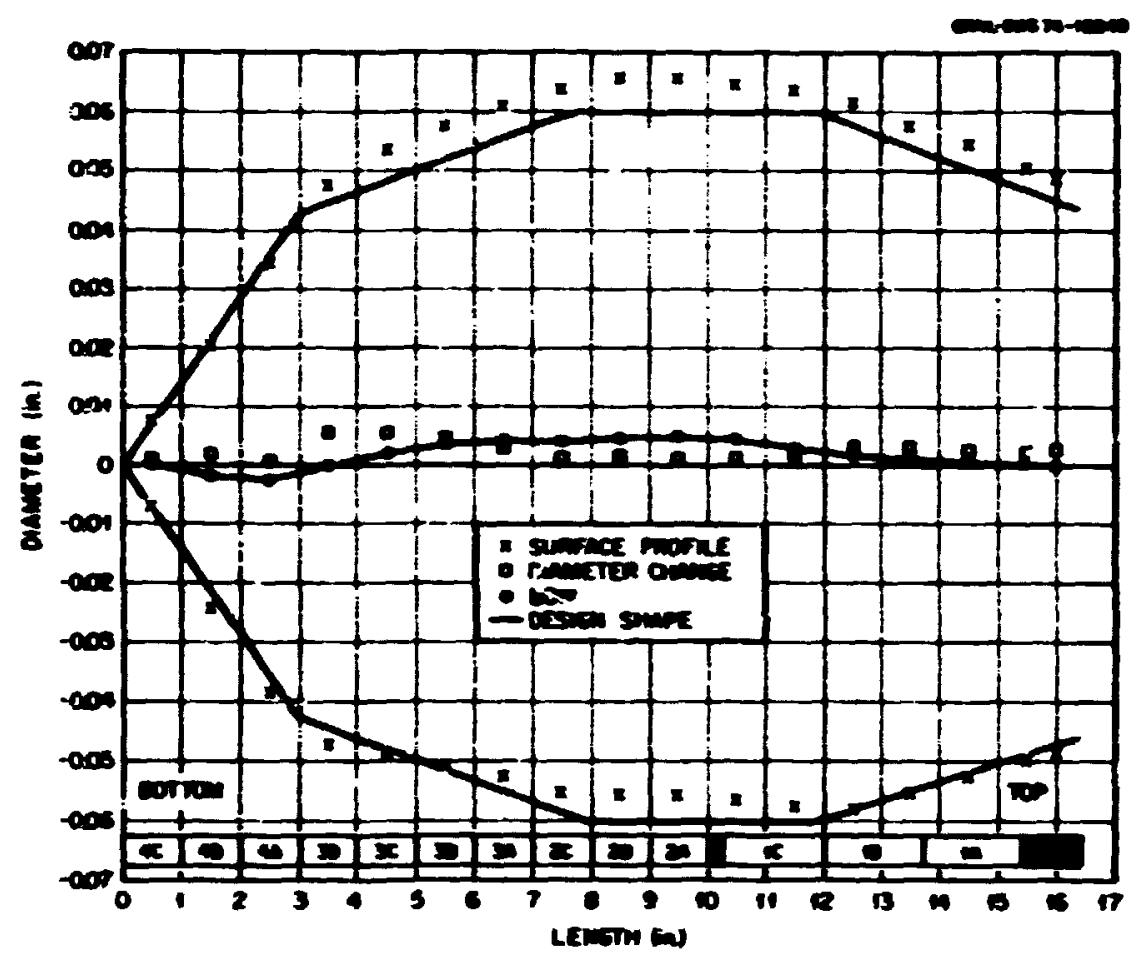

Fig. A-7. Graphite Sleeve Dinensions for Capsule HRb-5 $0^{\circ}$ Orfentation.

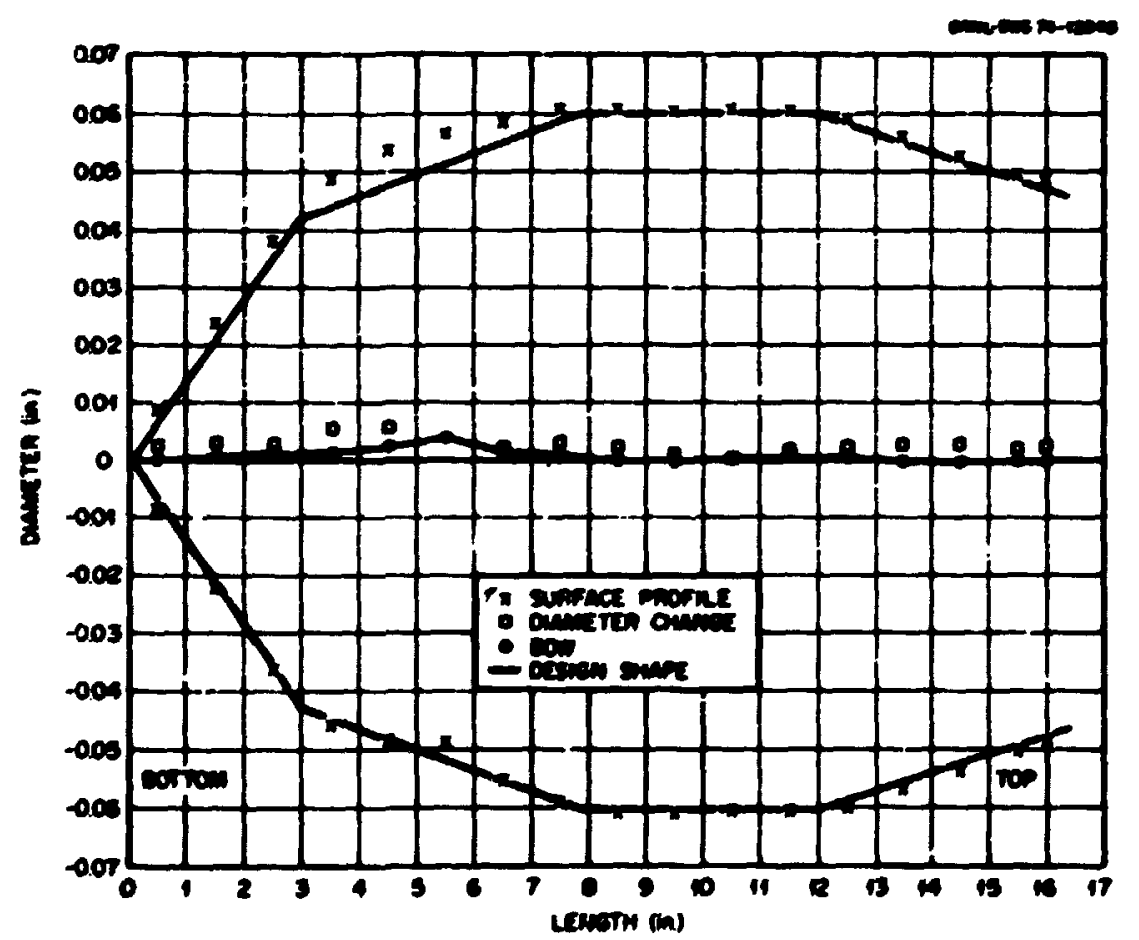

F18. A-8. Graphite Sleeve Dimensions for Capsule HRB-5 90* Orientation. 